Oliva-Madrid, M.-J.; García-López, J.-A.; Saura-Llamas, I.; Bautista, D.; Vicente, J. Ortho Palladation of the Phenethylamines of Biological Relevance I-Tyrosine Methyl Ester and Homoveratrylamine. Reactivity of the Palladacycles toward $\mathrm{CO}$ and Isocyanides. Synthesis of the Natural Alkaloid Corydaldine. Organometallics 2012, 31, 3647-3660.

DOI: doi.org/10.1021/om300141b

This document is the Accepted Manuscript version of a Published Work that appeared in final form in Organometallics, copyright (C) American Chemical Society, after peer review and technical editing by the publisher. To access the final edited and published work see https://pubs.acs.org/doi/10.1021/om300141b. 



\title{
REVISED
}

\section{Ortho-Palladation of the Phenethylamines of Biological}

\author{
Relevance, L-Tyrosine Methyl Ester and
}

Homoveratrylamine. Reactivity of the Palladacycles

towards CO and Isocyanides. Synthesis of the Natural

\section{Alkaloid Corydaldine}

María-José Oliva-Madrid, ${ }^{a}$ José-Antonio García-López, ${ }^{a}$ Isabel Saura-Llamas,,$*$ Delia Bautista ${ }^{b}$ and José Vicente ${ }^{a, *}$

\footnotetext{
a Grupo de Química Organometálica, Departamento de Química Inorgánica, Facultad de Química, Universidad de Murcia, Apartado 4021, E-30071 Murcia, Spain. ' SAI, Universidad de Murcia, Apartado 4021, E-30071 Murcia, Spain
}

AUTHOR EMAIL ADDRESS ims@um.es (I.S-L.); jvs1@um.es (J.V.)

RECEIVED DATE (to be automatically inserted after your manuscript is accepted if required according to the journal that you are submitting your paper to) 
ABSTRACT: The palladacycle derived from L-tyrosine methyl ester, $(S)-\left[\operatorname{Pd}_{2}\{C, N-\right.$ $\left.\left.\mathrm{C}_{6} \mathrm{H}_{3} \mathrm{CH}_{2} \mathrm{CH}\left(\mathrm{CO}_{2} \mathrm{Me}\right) \mathrm{NH}_{2}-2,(\mathrm{OH})-4\right\}_{2}(\mu-\mathrm{Br})_{2}\right] \quad(\mathbf{1 a}-\mathbf{B r}), \quad$ or $\quad$ homoveratrylamine, $\quad\left[\mathrm{Pd}_{2}\{C, N-\right.$ $\left.\left.\mathrm{C}_{6} \mathrm{H}_{2} \mathrm{CH}_{2} \mathrm{CH}_{2} \mathrm{NH}_{2}-6,(\mathrm{OMe})_{2}-3,4\right\}_{2}(\mu \text {-Br })_{2}\right]$ (1b-Br) can be easily prepared in good yield by reacting $\mathrm{Pd}(\mathrm{OAc})_{2}$, the corresponding ammonium triflate and $\mathrm{NaBr}$. Under the same reaction conditions, the reaction of $\mathrm{Pd}(\mathrm{OAc})_{2}$ with the free amine affords low yield of the corresponding acetato complex, 1aOAc or 1b-OAc (the latter only detected in solution). In our hands, the previously reported palladation at the $\mathrm{C} 2$ position of homoveratrylamine with $\mathrm{Pd}(\mathrm{OAc})_{2}$ is not observed. Instead, a complex mixture is obtained, mainly containing $\left[\mathrm{Pd}(\mathrm{OAc})_{2}\left\{\mathrm{NH}_{2} \mathrm{CH}_{2} \mathrm{CH}_{2} \mathrm{C}_{6} \mathrm{H}_{3}(\mathrm{OMe})_{2}-3,4\right\}_{2}\right]$ and minor amounts of 1b-OAc, which reacts with $\mathrm{NaBr}$ to afford a new mixture from which $\left[\mathrm{PdBr}_{2}\left\{\mathrm{NH}_{2} \mathrm{CH}_{2} \mathrm{CH}_{2} \mathrm{C}_{6} \mathrm{H}_{3}(\mathrm{OMe})_{2}-3,4\right\}_{2}\right]$ can be isolated and characterized. These and other adducts can be isolated from $\operatorname{Pd}(\mathrm{OAc})_{2}$, homoveratrylamine and various ligands $\left(\mathrm{PPh}_{3}\right.$ or $\left.\mathrm{Br}^{-}\right)$. 6-Bromohomoveratrylamine reacts with $\mathrm{Pd}(\mathrm{dba})_{2}$ in the presence of tmeda to give the complex $\left[\mathrm{Pd}\left\{\mathrm{C}, N-\mathrm{C}_{6} \mathrm{H}_{2} \mathrm{CH}_{2} \mathrm{CH}_{2} \mathrm{NH}_{2}-6,(\mathrm{OMe})_{2}-3,4\right\}(\mathrm{tmeda})\right] \mathrm{Br}$. Reactions of complexes 1 with acetylacetonato or neutral $\left(\mathrm{PR}_{3}\right)$ ligands give products resulting from substitution or bridge-splitting reactions. While complex $\mathbf{1 a - B r}$ reacts with XyNC (1:2 molar ratio) to give (S)-[Pd $\left.\left\{C, N-\mathrm{C}_{6} \mathrm{H}_{3} \mathrm{CH}_{2} \mathrm{CH}\left(\mathrm{CO}_{2} \mathrm{Me}\right) \mathrm{NH}_{2}-2,(\mathrm{OH})-4\right\} \mathrm{Br}(\mathrm{CNXy})\right], \mathbf{1 b}-\mathrm{Br}$ gives $[\mathrm{Pd}\{C, N-\mathrm{C}(=\mathrm{NXy})-$ $\left.\left.\mathrm{C}_{6} \mathrm{H}_{2} \mathrm{CH}_{2} \mathrm{CH}_{2} \mathrm{NH}_{2}-6,(\mathrm{OMe})_{2}-3,4\right\} \mathrm{Br}(\mathrm{CNXy})\right] . \quad$ (S)-7-Hydroxy-3-(methoxycarbonyl)-3,4dihydroisoquinolin-1(2H)-one and 6,7-dimethoxy-3,4-dihydroisoquinolin-1(2H)-one (corydaldine) are synthesized through the stoichiometric carbonylation of palladacycles $\mathbf{1 a - B r}$ and $\mathbf{1 b}-\mathbf{B r}$. The crystal structures of a solvento-intermediate in the ortho-metalation reaction of the triflate derivative of Ltyrosine methyl ester, and four other complexes have been determined by X-ray diffraction studies.

\section{INTRODUCTION}


Ortho-palladated complexes have been widely used as precatalysts in organic synthesis ${ }^{1,2}$ or as reagents toward unsaturated compounds to afford organic derivatives of the corresponding arenes. ${ }^{2-4} \mathrm{We}$ have contributed to this last topic, ${ }^{5}$ preparing organic derivatives of benzyl- ${ }^{6}$ and phenethyl-amines ${ }^{7-10}$ by reaction of the corresponding cyclopalladated complexes with $\mathrm{CO}, \mathrm{RNC}, \mathrm{RNCS}$, halogens, or olefins. A parallel study is being carried out with orthopalladated benzylamines. ${ }^{11}$ We are particularly interested in using this method to prepare derivatives of phenethylamines because some pharmaceuticals (i.e., amphetamines) and biologically active amino acids belong to this family of compounds. ${ }^{12}$

For a long time, primary arylalkylamines were believed to be inert toward direct activation of $\mathrm{C}-\mathrm{H}$ bonds by $\mathrm{Pd}(\mathrm{II}),{ }^{13}$ but their cyclometalation was proved to be possible when the adequate reaction conditions were used. ${ }^{14,15}$ Nevertheless, most derived halogen-bridged ortho-metalated complexes were obtained in low to moderate yields $(17-63 \%){ }^{8,16-18}$ Very recently, we have found that those yields can be significantly improved if the ortho-palladation reactions are carried out using the corresponding ammonium triflates as starting materials, instead of the free amines or their hydrochlorides. ${ }^{19}$ For instance, the dimeric bromo-bridged palladacycle derived from L-phenylalanine methyl ester can be obtained from $\mathrm{Pd}(\mathrm{OAc})_{2}, \mathrm{NaBr}$ and: (1) L-phenylalanine methyl ester hydrochloride, in $49 \%$ yield, ${ }^{8}$ or (2) the triflate derived of L-phenylalanine methyl ester, in $89 \%$ yield (Scheme 1). ${ }^{19}$

Scheme 1. Reported Syntheses of the Bromo-bridged Ortho-palladated Derivative of (L)-Phenylalanine Methyl Ester.

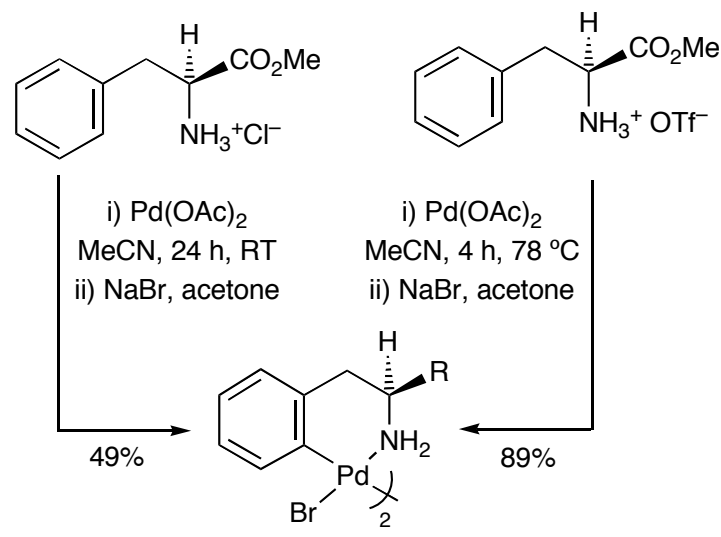


We report in this work the application of this improved method to (1) the synthesis of the new palladacycle derived from L-tyrosine methyl ester, a derivative of a natural amino acid and (2) improve the yield of the previously reported product of the ortho-palladation of homoveratrylamine, ${ }^{20}$ a hallucinogenic compound closely related to the amphetamines family. ${ }^{12}$ This second objective was not achieved because, in our hands, the ortho-palladation of homoveratrylamine takes place in a position of the aryl ring different from that reported.$^{20}$ We also (1) analyze the differences and advantages of using the triflate salts instead of the free amines as starting materials in these ortho-metalation reactions, (2) prepare some derivatives of the cyclopalladated complexes by reacting them with anionic and neutral ligands, and (3) prepare the lactams derived of both phenethylamines via carbonylation of their corresponding palladacycles.

\section{RESULTS AND DISCUSSION}

Synthesis of Ortho-Palladated Complexes. Consistent with our recently described method of orthopalladation of primary arylalkylamines, ${ }^{19}$ the ammonium triflate derived from L-tyrosine methyl ester,
$(S)-\left[4-\mathrm{OH}-\mathrm{C}_{6} \mathrm{H}_{4} \mathrm{CH}_{2} \mathrm{CH}\left(\mathrm{CO}_{2} \mathrm{Me}\right) \mathrm{NH}_{3}\right] \mathrm{OTf}$
(A),
or
homoveratrylamine,
$[3,4-$

$\left.(\mathrm{MeO})_{2} \mathrm{C}_{6} \mathrm{H}_{3} \mathrm{CH}_{2} \mathrm{CH}_{2} \mathrm{NH}_{3}\right] \mathrm{OTf}(\mathbf{B})$, reacted with $\mathrm{Pd}(\mathrm{OAc})_{2}$ in a 1:1 molar ratio, in acetonitrile at $78{ }^{\circ} \mathrm{C}$, to give HOAc and, likely, an ortho-metalated solvento-intermediate (Ia·2S, Ib·2S; Scheme 2), which in turn reacted with $\mathrm{NaBr}$ to afford the bromo-bridged cyclopalladated complex $\mathbf{1 a - B r}$ or $\mathbf{1 b}-\mathbf{B r}$. The addition of NaOAc to solutions of the intermediate $\mathbf{I b}$ in acetone afforded the acetato-bridged complex 1b-OAc, which could not be isolated pure from the reaction mixture. The metathesis reaction between 1b-Br and NaOAc afforded complex 1b-OAc contaminated with unreacted $\mathbf{1 b}-\mathbf{B r}$, even when long reaction times and a large excess of $\mathrm{NaOAc}$ were used. However, the reaction of complex $\mathbf{1 b}$ - $\mathbf{B r}$ with $\mathrm{AgClO}_{4}$ in a 1:2 molar ratio, and the subsequent addition of $\mathrm{NaOAc}$, allowed the synthesis of pure 1bOAc (Scheme 2).

When $\mathbf{1 b}-\mathbf{B r}$ was treated with $[\mathrm{Tl}(\mathrm{acac})](\mathrm{Hacac}=$ acetylacetone $)$, precipitation of $\mathrm{TlBr}$ took place and the complex $\left[\mathrm{Pd}\left\{C, N-\mathrm{C}_{6} \mathrm{H}_{2} \mathrm{CH}_{2} \mathrm{CH}_{2} \mathrm{NH}_{2}-6,(\mathrm{OMe})_{2}-3,4\right\}\left(O, O^{\prime}\right.\right.$-acac)] (2b) was obtained (Scheme 2). Complex 1a-Br, 1b-Br or $1 \mathbf{b - O A c}$ reacted with two equiv of $\mathrm{PR}_{3}(\mathrm{R}=\mathrm{Ph}, p$-To $)$ to give the 
mononuclear phosphino adduct $\left[\mathrm{Pd}\left\{C, N-\mathrm{C}_{6} \mathrm{H}_{3} \mathrm{CH}_{2} \mathrm{CH}\left(\mathrm{CO}_{2} \mathrm{Me}\right) \mathrm{NH}_{2}-2,(\mathrm{OH})-4\right\} \mathrm{Br}\left(\mathrm{PPh}_{3}\right)\right](3 \mathbf{a}-\mathbf{B r})$ or $\left[\mathrm{Pd}\left\{\mathrm{C}, N-\mathrm{C}_{6} \mathrm{H}_{2} \mathrm{CH}_{2} \mathrm{CH}_{2} \mathrm{NH}_{2}-6,(\mathrm{OMe})_{2}-3,4\right\} \mathrm{X}\left(\mathrm{PR}_{3}\right)\right](\mathrm{X}=\mathrm{Br}, \mathrm{R}=\mathrm{Ph}(\mathbf{3 b}-\mathbf{B r})$, To (3b'-Br); $\mathrm{X}=\mathrm{OAc}, \mathrm{R}=$ $\mathrm{Ph}$ (3b-OAc); Scheme 2).

Scheme 2. Synthesis of Palladacycles Containing L-Tyrosine Methyl Ester and Homoveratrylamine
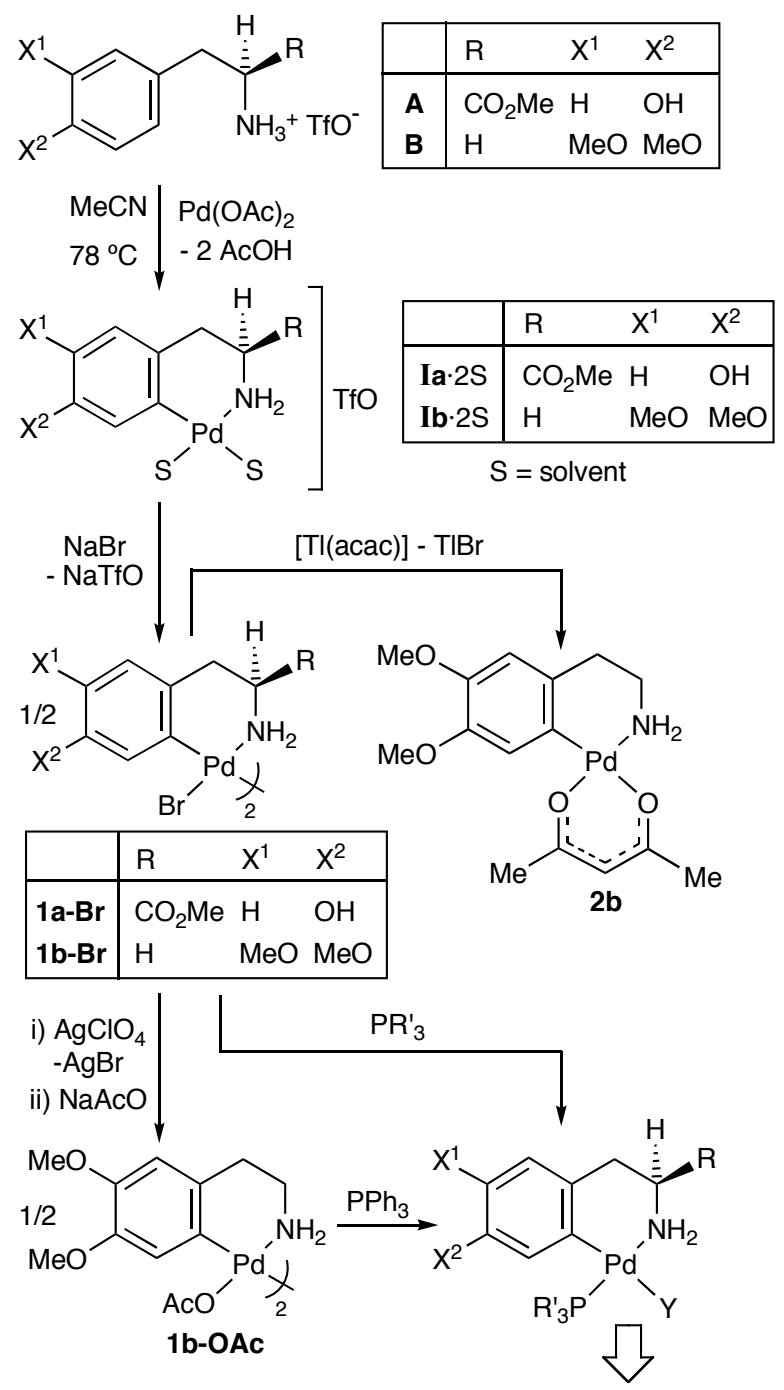

\begin{tabular}{llllll} 
& $\mathrm{R}$ & $\mathrm{Y}$ & $\mathrm{X}^{1}$ & $\mathrm{X}^{2}$ & $\mathrm{R}^{\prime}$ \\
\hline 3a-Br & $\mathrm{CO}_{2} \mathrm{Me}$ & $\mathrm{Br}$ & $\mathrm{H}$ & $\mathrm{OH}$ & $\mathrm{Ph}$ \\
3b-Br & $\mathrm{H}$ & $\mathrm{Br}$ & $\mathrm{MeO}$ & $\mathrm{MeO}$ & $\mathrm{Ph}$ \\
3b-OAc & $\mathrm{H}$ & $\mathrm{AcO}$ & $\mathrm{MeO}$ & $\mathrm{MeO}$ & $\mathrm{Ph}$ \\
3b'-Br & $\mathrm{H}$ & $\mathrm{Br}$ & $\mathrm{MeO}$ & $\mathrm{MeO}$ & $p-\mathrm{To}$
\end{tabular}

Complex 1a-Br reacted with two equiv of $\mathrm{XyNC}$ to give $\left[\mathrm{Pd}\left\{C, N-\mathrm{C}_{6} \mathrm{H}_{3} \mathrm{CH}_{2} \mathrm{CH}\left(\mathrm{CO}_{2} \mathrm{Me}\right) \mathrm{NH}_{2}-6,(\mathrm{OH})\right.\right.$ 4\}Br(CNXy)] (4a) (Scheme 3). When an analogous reaction was tried using $\mathbf{1 b}-\mathbf{B r}$ as starting material, a mixture of the unreacted bromo-bridged cyclometalated compound and the complex $[\operatorname{Pd}\{C, N$ $\left.\left.\mathrm{C}(=\mathrm{NXy})-\mathrm{C}_{6} \mathrm{H}_{2} \mathrm{CH}_{2} \mathrm{CH}_{2} \mathrm{NH}_{2}-6,(\mathrm{OMe})_{2}-3,4\right\} \mathrm{Br}(\mathrm{CNXy})\right]$ (5b) was isolated. Complex 5b could be 
prepared in good yield by reaction of complex $\mathbf{1 b}-\mathbf{B r}$ with four equiv of XyNC. The same reaction with 1a-Br gave a solid insoluble in all common organic solvents.

The mechanism of the insertion of isocyanides into the $\mathrm{Pd}-\mathrm{C}$ bond, that has been thoroughly studied, involves (1) coordination of the ligand to the metal center and (2) migratory insertion of the aryl group to the coordinated isocyanide..$^{621-24}$ According to this mechanism, the different behavior between palladacycles $\mathbf{1 a - B r}$ and $\mathbf{1 b}-\mathbf{B r}$ towards isocyanide insertion can be attributed to the increased nucleophilicity of the carbon atom bonded to palladium(II) in the homoveratrylamine derivative, which favors the insertion of the isocyanide into the $\mathrm{Pd}-\mathrm{C}$ bond..$^{24,25}$ The easy insertion of the isocyanide into the $\mathrm{Pd}-\mathrm{C}$ bond of $\mathbf{1 b}-\mathbf{B r}$ resembles the behavior of the palladacycle derived from benzyl methyl sulfide, which undergo rapid isocyanide insertion at room temperature, ${ }^{22}$ and contrasts with that exhibited by complexes derived from classical $N, N$-bencylamines, for which high temperatures or an excess of isocyanide are required to obtain the iminoacyl complexes. ${ }^{6,21}$

Scheme 3. Reactions of Ortho-Palladated Complexes with XyNC

\begin{tabular}{|l|lll|}
\hline & $\mathrm{R}$ & $\mathrm{X}^{1}$ & $\mathrm{X}^{2}$ \\
\hline $\mathbf{1 a}-\mathrm{Br}$ & $\mathrm{CO}_{2} \mathrm{Me}$ & $\mathrm{H}$ & $\mathrm{OH}$ \\
$\mathbf{1 b}-\mathrm{Br}$ & $\mathrm{H}$ & $\mathrm{MeO}$ & $\mathrm{MeO}$ \\
\hline
\end{tabular}
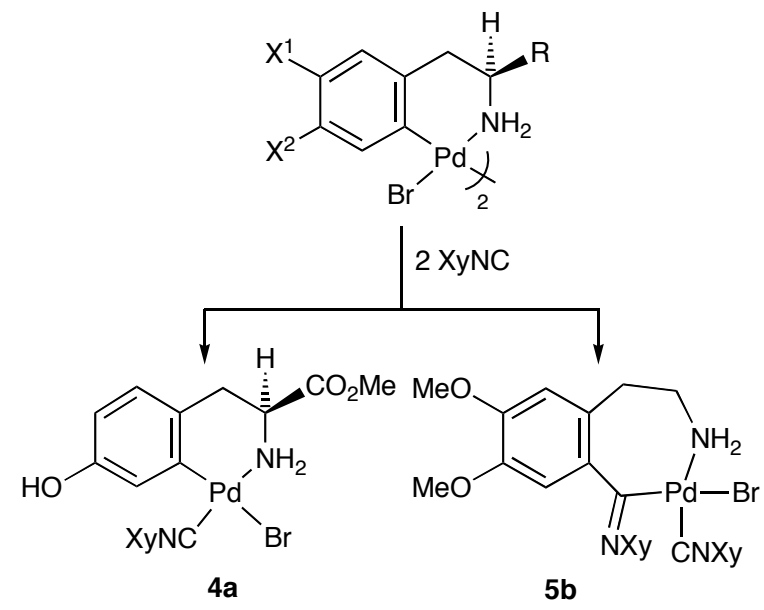

The NMR data support the structures of compounds 1-5 shown in Schemes 2 and 3. The ${ }^{1} \mathrm{H}$ NMR spectra of homoveratrylamine derivatives show that only the isomer palladated at C6 was obtained. Thus, for non-phosphino complexes (1b-Br, 1b-OAc, $\mathbf{2 b}$ and $\mathbf{5 b}) \mathrm{H} 2$ and H5 protons give singlets ( $\delta$ : 
6.43-6.68 $(\mathrm{H} 2), 6.69-7.60(\mathrm{H} 5))$. Coordination of $\mathrm{PR}_{3}$ to the metal produces, with respect to its precursor, a large shielding of the aromatic proton next to the metalated carbon (e.g., $\delta(H 5): 6.69$ (1bOAc), 6.01 (3b-OAc)) and of the adjacent methoxy protons of the homoveratrylamine derivatives (e.g., $\delta(\mathrm{MeO}): 3.80,3.81$ (1b-OAc), 3.02 (3b-OAc)), as observed in other cases ${ }^{26}$ Additionally, coupling of H5 with ${ }^{31} \mathrm{P}$ nucleus was observed in all complexes $\left({ }^{4} J_{\mathrm{HP}}=4.8-5.2 \mathrm{~Hz}\right)$. These features are consistent with coordination of the $\mathrm{PPh}_{3}$ in trans position to the amino group, ${ }^{27}$ which is the expected geometry taking into account the great transphobia ${ }^{28}$ between $\mathrm{PPh}_{3}$ and aryl ligands. ${ }^{29,30}{ }^{1} \mathrm{H}$ and ${ }^{13} \mathrm{C}$ NMR spectra of complex $\mathbf{5 b}$ show the restricted rotation of the Xy group of the inserted isocyanide, probably caused by steric hindrance. We propose that, in both complexes, the coordinated isocyanide is located in trans position to the amino group, because this is the normal behavior for palladacycles containing arylalkylamines, ${ }^{6,9,10,21,23,31,32}$ and it is in agreement with the well-established transphobia between Cdonor ligands..$^{29,33}$

On the Ortho-Palladation of Homoveratrylamine. Our results on the ortho-metalation of homoveratrylamine agree with those obtained by other authors for similar N-ligands. For instance, Vila et al. have studied the influence on the metalation position of different substituents at the aromatic ring in some Schiff bases,$^{34}$ and conclude that a methoxy group at the C3 hinders palladation at C2. Pfeffer et al. have observed similar steric hindrance in the synthesis of cyclometalated ruthenium(II) complexes containing substituted $N, N$-dimethylbenzylamines. ${ }^{35}$ Direct palladation of $N, N$-diethyl-3-methoxy-4benzyloxy-benzylamine, ${ }^{26} \quad N, N$-dimethyl-3,4-dimethoxybenzylamine, ${ }^{36} \quad N$-methyl- $N$-buthyl-3,4dimethoxybenzylamine, ${ }^{37} \quad N$-buthyl-3,4-dimethoxybenzylamine, ${ }^{38} \quad N$ - $(3,4-$ dimethoxybenzylidene)benzenamine ${ }^{39} \mathrm{~N}$-(3,4-dimethoxybenzylidene)-2,4,6-trimethylbenzenamine ${ }^{40} \mathrm{~N}$ (2-hydroxoethyl)-3,4-dimethoxybenzylideneamine, ${ }^{41} \quad N$-(2,6-dichlorobenzylidene)-2-(3,4dimethoxyphenyl)ethylamine, ${ }^{42}$ and 4-(3,4-dimethoxybenzylidene)-2-(3,4-dimethoxyphenyl)oxazol$5(4 H)$-one $^{43}$ (among others) have also been reported to occur regiospecifically at the C6 position. Surprisingly, Hajipour et al. ${ }^{20}$ described the reaction between homoveratrylamine and $\operatorname{Pd}(\mathrm{OAc})_{2}$ in 
acetonitrile at $80{ }^{\circ} \mathrm{C}$ to give the ortho-palladated complex at $\mathrm{C} 2$ position. The acetato-bridged complex could not be isolated pure, but metathesis reaction with $\mathrm{NaBr}$ afforded the corresponding bromo-bridged derivative (Scheme 4) in a 39\% overall yield (based on $\mathrm{Pd}(\mathrm{OAc})_{2}$ ).

Scheme 4. Reported Synthesis of Palladacycles Containing Homoveratrylamine ${ }^{20}$

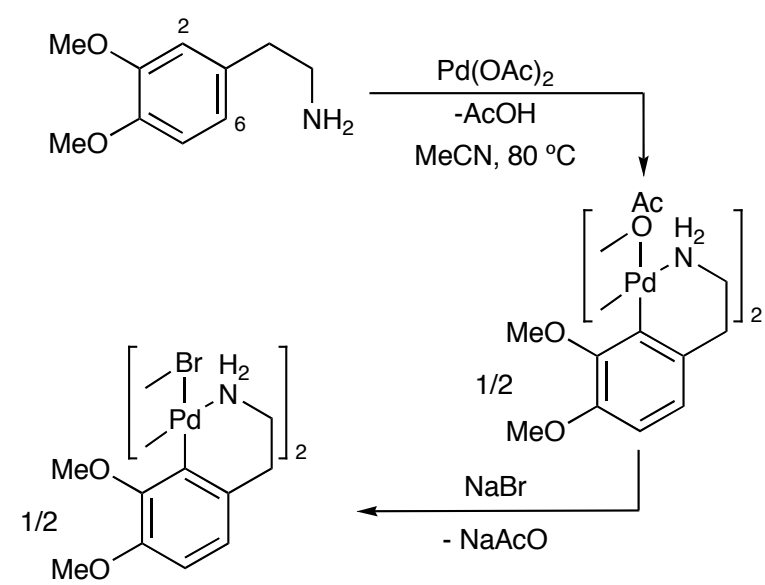

With the aim of elucidating if the use of the triflate salt instead of the free amine as starting material could modify the result of the metalation reaction, we repeated it under the same conditions used by Hajipour et al. ${ }^{20}$ However, in our hands, when a 1:1 mixture of homoveratrylamine and $\operatorname{Pd}(\mathrm{OAc})_{2}$ was refluxed in acetonitrile for $4 \mathrm{~h}$, a dark orange solid $\mathbf{X}$ could be isolated, along with metallic palladium. The ${ }^{1} \mathrm{H}$ NMR spectrum of $\mathbf{X}$ (Figure 1, spectrum b) corresponds to a mixture in which $\left[\mathrm{Pd}(\mathrm{OAc})_{2}\left\{\mathrm{NH}_{2} \mathrm{CH}_{2} \mathrm{CH}_{2} \mathrm{C}_{6} \mathrm{H}_{3}(\mathrm{OMe})_{2}-3,4\right\}_{2}\right]$ (6b-OAc; signals marked with red circles in Figure 1) is the major component, and the ortho-palladated complex 1b-OAc (signals marked with green stars in Figure $1)$ is also present. Using other reaction times $(4-48 \mathrm{~h})$ and temperatures $\left(25-80^{\circ} \mathrm{C}\right)$, mixtures very similar to $\mathbf{X}$ were obtained. We could not discard that a small amount of the ortho-metalated complex at C2 position was present in this mixture, since their ${ }^{1} \mathrm{H}$ NMR signals could be obscured by those corresponding to other components (Figure 1, spectra b-e). When $\mathbf{X}$ was treated with an excess of $\mathrm{NaBr}$, a new mixture was obtained from which complex $\left[\mathrm{PdBr}_{2}\left\{\mathrm{NH}_{2} \mathrm{CH}_{2} \mathrm{CH}_{2} \mathrm{C}_{6} \mathrm{H}_{3}(\mathrm{OMe})_{2}-3,4\right\}_{2}\right](6 \mathbf{b}-$ Br) could be isolated in a $48 \%$ yield. Complexes $6 \mathbf{b - O A c}$ and $\mathbf{6 b - B r}$ were independently prepared by reaction of $\mathrm{Pd}(\mathrm{OAc})_{2}$ and the free amine at room temperature in a 1:2 molar ratio (Scheme 5). To characterize the components of $\mathbf{X}$, the reaction of $\mathbf{6 b - O A c}$ or $\mathbf{6 b - B r}$ with one equiv of $\mathrm{PPh}_{3}$ was carried 
out and $\left[\mathrm{PdX}_{2}\left\{\mathrm{NH}_{2} \mathrm{CH}_{2} \mathrm{CH}_{2} \mathrm{C}_{6} \mathrm{H}_{3}(\mathrm{OMe})_{2}-3,4\right\}\left(\mathrm{PPh}_{3}\right)\right](\mathrm{X}=\mathrm{OAc}$ (7b-OAc), $\mathrm{Br}(7 \mathbf{b}-\mathrm{Br})$; Scheme 5) was isolated. Surprisingly, the phosphino ligand only displaced one of the two amines coordinated to palladium(II), even when an excess of $\mathrm{PPh}_{3}$ was used.

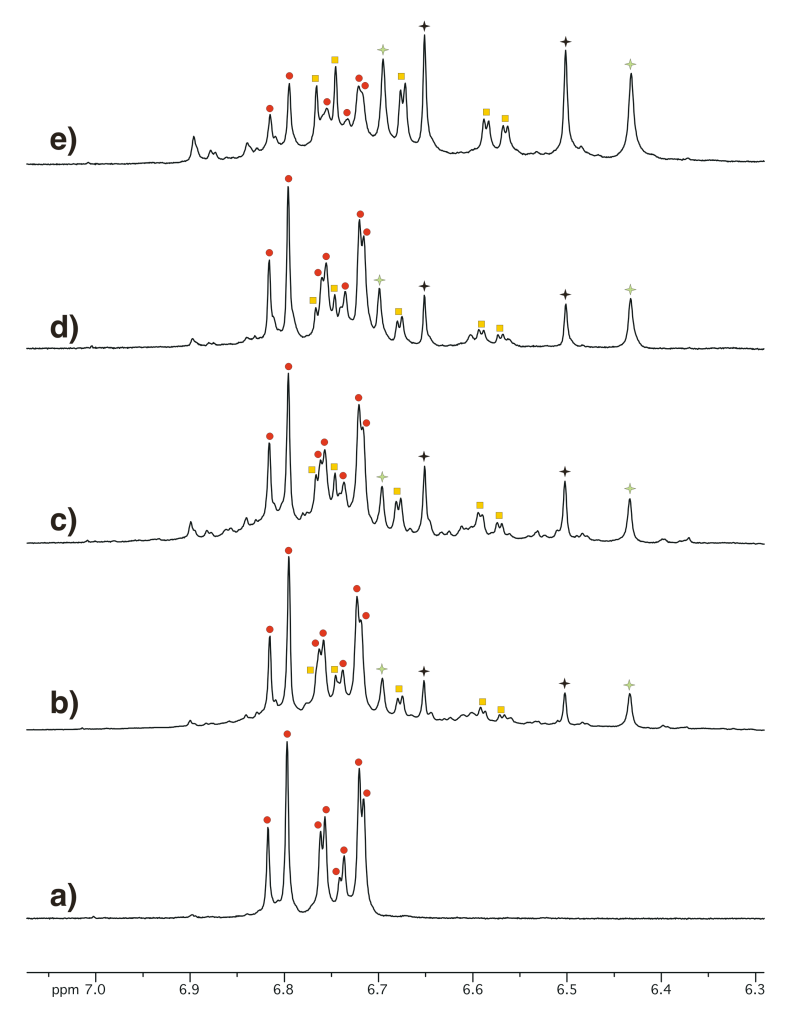

Figure 1. ${ }^{1} \mathrm{H}$ NMR (6.4-7.0 ppm) spectra of complex 6b-OAc (a), and mixture $\mathbf{X}$ obtained from the reaction of $\mathrm{Pd}(\mathrm{OAc})_{2}$ and free homoveratrylamine in acetonitrile at different reaction times and temperatures: $4 \mathrm{~h}$ at $80{ }^{\circ} \mathrm{C}(\mathrm{b}), 7 \mathrm{~h}$ at $78{ }^{\circ} \mathrm{C}(\mathrm{c}), 7$ days at room temperature (d), $2 \mathrm{~h}$ at $70{ }^{\circ} \mathrm{C}$ and then 48 $\mathrm{h}$ at room temperature (e). Signals corresponding to complex 6b-OAc are marked with red circles; signals of complex 1b-OAc, with green stars. At least, other two species are present in mixture $\mathbf{X}$ : an ortho-metalated complex at C6 position (signals marked with black stars) and a non ortho-metalated compound (signals marked with yellow squares).

We have proved ${ }^{15,17,18}$ that the reaction of $\mathrm{Pd}(\mathrm{OAc})_{2}$ with one equiv of arylalkylamines in acetonitrile, gives initially the complex $\left[\mathrm{Pd}(\mathrm{OAc})_{2}(\text { amine })_{2}\right]$, which further reacts with the remaining $\operatorname{Pd}(\mathrm{OAc})_{2}$ to give the dinuclear complex $\left[\mathrm{Pd}_{2}(\mu-\mathrm{OAc})_{2}(\mathrm{OAc})_{2}(\text { amine })_{2}\right]$ (Scheme 5), which, in turn, can undergo the ortho-palladation reaction upon heating in acetonitrile. By reacting at room temperature $\operatorname{Pd}(\mathrm{OAc})_{2}$ and one equiv of homoveratrylamine in $\mathrm{CH}_{2} \mathrm{Cl}_{2}$, a mixture was obtained after one hour from which 
complexes 6b-OAc $(40 \%)$ and $\left[\mathrm{Pd}_{2}(\mu-\mathrm{OAc})_{2}(\mathrm{OAc})_{2}\left\{\mathrm{NH}_{2} \mathrm{CH}_{2} \mathrm{CH}_{2} \mathrm{C}_{6} \mathrm{H}_{3}(\mathrm{OMe})_{2}-3,4\right\}_{2}\right](\mathbf{8 b} ; 35 \%)$ were isolated. When longer reaction times were used, complex $\mathbf{8 b}$ evolved to a mixture $\mathbf{Y}$, which contained some of the species present in the mixture $\mathbf{X}$. Moreover, when heated in the solid state, complex $\mathbf{8 b}$ also evolved to the mixture Y (Figure 2). The complex 7b-OAc (Scheme 5) could also be prepared by reaction of $\mathbf{8 b}$ with two equiv of $\mathrm{PPh}_{3}$.

Scheme 5. Synthesis of non Ortho-Palladated Complexes Containing Homoveratrylamine

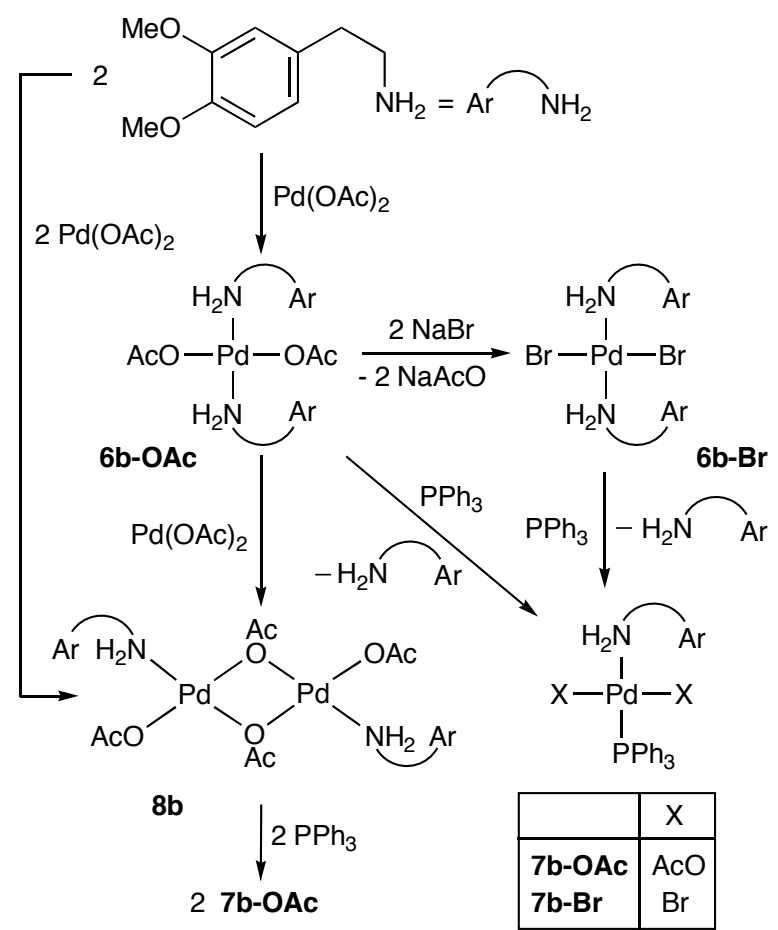

In addition of complexes 6b-OAc (present in mixture $\mathbf{X}$ ), $\mathbf{8 b}$ (present in mixture $\mathbf{Y}$ ), and 1b-OAc (present in $\mathbf{X}$ and $\mathbf{Y}$ ), two other sets of signals were observed in the ${ }^{1} \mathrm{H}$ NMR spectra (in $\mathrm{CDCl}_{3}$ ) of both mixtures: one pair of singlets at 6.50 and $6.65 \mathrm{ppm}$ (relative intensities $=1: 1$ ), probably corresponding to an ortho-palladated compound at C6 position $(\mathbf{C})$, and a doublet of doublets $\left(\delta: 6.57,{ }^{3} J_{\mathrm{HH}}=8.0,{ }^{4} J_{\mathrm{HH}}\right.$ $=2.0 \mathrm{~Hz})$ plus two doublets $\left(\delta: 6.67,{ }^{4} J_{\mathrm{HH}}=2.0 \mathrm{~Hz} ; 6.75,{ }^{3} J_{\mathrm{HH}}=8.0 \mathrm{~Hz}\right)$ with relative intensities $1: 1: 1$, that could be assigned to a non ortho-palladated complex (D). In order to characterize $\mathbf{C}$ and $\mathbf{D}$, we reacted mixtures $\mathbf{X}$ and $\mathbf{Y}$ with 1-2 equiv $\mathrm{PPh}_{3} / \mathrm{Pd}$, which afforded a mixture of two complexes in both cases, as observed by ${ }^{31}$ P NMR: 3b-OAc (Scheme 2), formed from 1b-OAc (Scheme 2) and C, and 7bOAc, formed from 6b-OAc, $8 \mathbf{b}$ (Scheme 5) and D. Consistent with these data, $\mathbf{C}$ could be an isomer of 
1b-OAc (Scheme 2) and $\mathbf{D}$ an isomer of $\mathbf{8 b}$ or $\mathbf{6 b - O A c}$, because they would give the same complexes with $\mathrm{PPh}_{3}$ that $\mathbf{1 b - O A c}$ and $\mathbf{8 b}$ or $\mathbf{6 b - O A c}$, respectively.

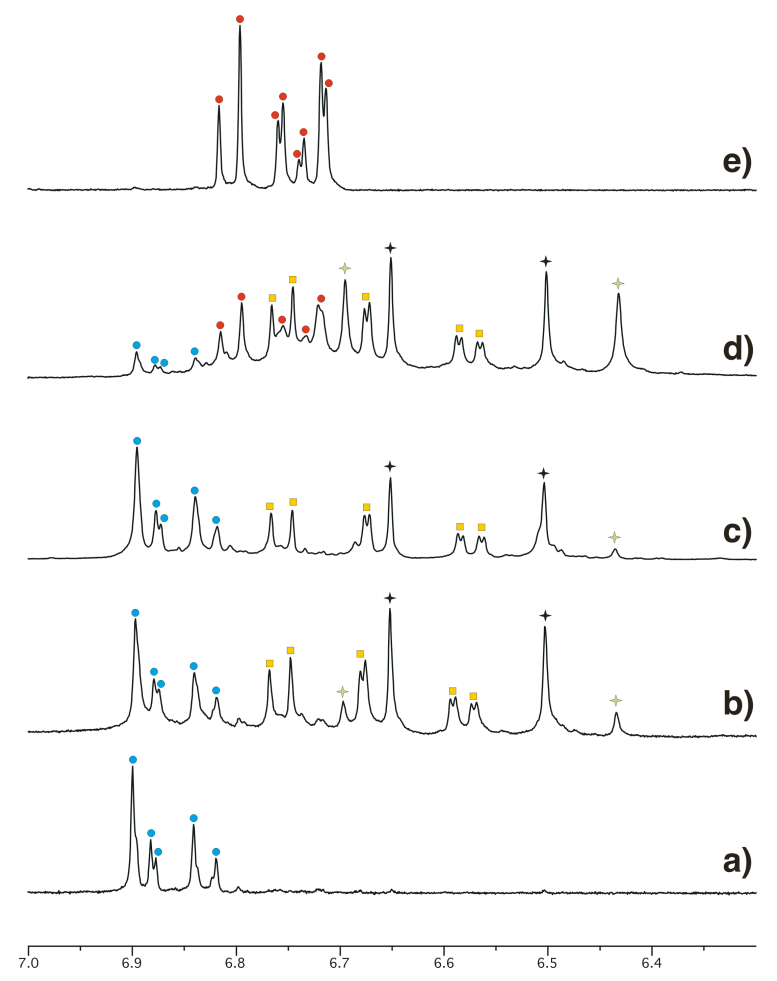

Figure 2. ${ }^{1} \mathrm{H}$ NMR (6.4-7.0 ppm) spectra of: (a) complex $\mathbf{8 b}$, (b) mixture $\mathbf{Y}$, obtained when a solution of complex $\mathbf{8 b}$ in $\mathrm{CH}_{2} \mathrm{Cl}_{2}$ is maintained at room temperature for $40 \mathrm{~h}$, (c) mixture $\mathbf{Y}$, obtained by heating solid $8 \mathbf{b}$ at $65{ }^{\circ} \mathrm{C}$ for $5 \mathrm{~h}$, (d) mixture $\mathbf{X}$, and (e) complex 6b-OAc. Signals corresponding to complex 6b-OAc are marked with red circles; signals of complex $\mathbf{8 b}$, blue circles; signals of complex 1b-OAc, green stars. Two other species are present in both mixtures: an ortho-palladated complex at C6 position (signals marked with black stars) and a non ortho-palladated compound (signals marked with yellow squares).

The crystal structures of complexes 6b-Br (Figure 3), $\mathbf{6 b - O A c} \cdot \mathrm{H}_{2} \mathrm{O}$ (Figure 4) and 7b-OAc (Figure 5) have been determined by X-ray diffraction. The molecules of complexes $\mathbf{6 b}-\mathbf{B r}$ and $\mathbf{6 b}-\mathbf{O A c} \cdot \mathrm{H}_{2} \mathrm{O}$ are centrosymmetric, with the palladium atoms coordinated to two bromo (6b-Br) or two terminal acetato (6b-OAc $\left.\cdot \mathrm{H}_{2} \mathrm{O}\right)$ ligands and the nitrogen atoms of two amines, in an almost perfect square-planar geometry. For complex $\mathbf{6 b - B r}$ there are two independent molecules in the asymmetric unit. The amino ligands adopt a mutually trans disposition, which is the normal geometry for this type of complexes. ${ }^{7,44}$ 
In complex $\mathbf{7 b - O A c}$, the palladium(II) center is bound to the $\mathrm{NH}_{2}$ group of the homoveratrylamine, one triphenylphosphine and two trans acetato ligands. To our knowledge this is the first structurally characterized bis-acetato-complex of $\mathrm{Pd}(\mathrm{II})$ containing a primary arylalkylamine and a phosphino ligand, although the crystal structures of complexes of the type trans-[ $\left.\mathrm{PdCl}_{2}(\operatorname{arylalkylamine})\left(\mathrm{PR}_{3}\right)\right]$ have been reported. ${ }^{45}$

The molecules of complex $\mathbf{6 b}-\mathbf{B r}$ and $\mathbf{6 b}-\mathbf{O A c} \cdot \mathrm{H}_{2} \mathrm{O}$ are associated through $\mathrm{N}-\mathrm{H} \cdots \mathrm{Br}$ and $\mathrm{N}-\mathrm{H} \cdots \mathrm{O}_{\mathrm{OAc}}$ hydrogen bonds to give chains and double chains, respectively. In complex $\mathbf{6 b}-\mathbf{B r}$, the chains are connected through a weak interaction $\mathrm{C}_{\mathrm{OMe}}-\mathrm{H}^{\cdots} \mathrm{O}_{\mathrm{OMe}}$ to generate layers, while in complex $\mathbf{6 b}-\mathbf{O A c} \cdot \mathrm{H}_{2} \mathrm{O}$ the chains are connected through $\mathrm{O}-\mathrm{H} \cdots \mathrm{O}_{\mathrm{OAc}}$ hydrogen bonds involving the crystallization water, to form a tridimensional net. In complex 7b-OAc, two adjacent molecules are connected through four $\mathrm{N}-$ $\mathrm{H} \cdots \mathrm{O}_{\mathrm{OAc}}$ hydrogen bonds to give dimers which, in turn, are connected through non classical $\mathrm{C}-\mathrm{H} \cdots \mathrm{O}_{\mathrm{OAc}}$ hydrogen bonds to give double chains along the $a$ axis (see Supporting Information).

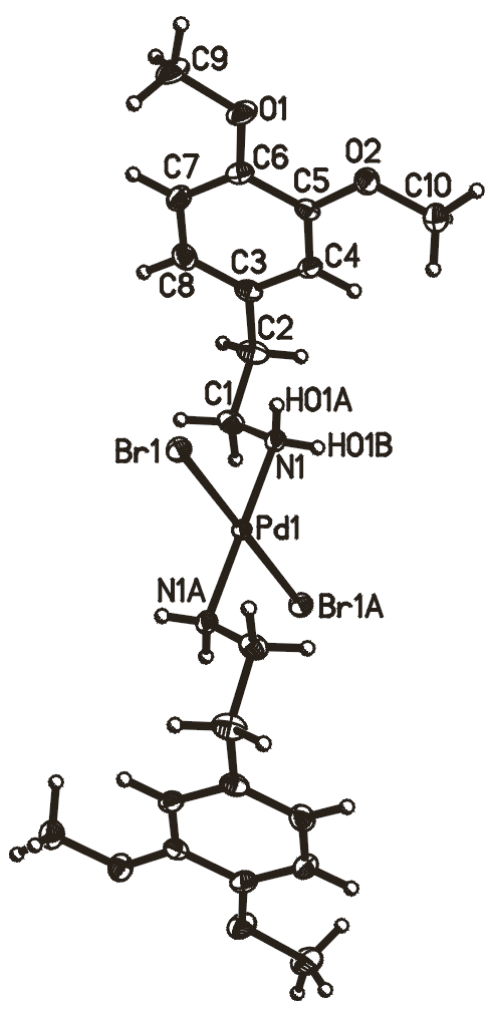

Figure 3. X-ray thermal ellipsoid plot of one (A) of the two independent molecules of complex $\mathbf{6 b - B r}$ (50\% probability) showing the labeling scheme. Selected bond lengths (§) and angles (deg) are given for both independent molecules. For A: $\operatorname{Pd}(1)-\mathrm{N}(1)=2.029(2), \operatorname{Pd}(1)-\operatorname{Br}(1)=2.4213(3)$; $\mathrm{N}(1)-\operatorname{Pd}(1)-$ 
$\operatorname{Br}(1)=89.33(7), N(1)-\operatorname{Pd}(1)-\operatorname{Br}(1 \mathrm{~A})=90.67(7)$. For $\mathrm{B}: \operatorname{Pd}(2)-\mathrm{N}(2)=2.030(2), \operatorname{Pd}(2)-\operatorname{Br}(2)=$ $2.4276(3) ; \mathrm{N}(2)-\operatorname{Pd}(2)-\mathrm{Br}(2)=88.73(7), \mathrm{N}(2)-\operatorname{Pd}(2)-\mathrm{Br}(2 \mathrm{~A})=91.27(7)$.

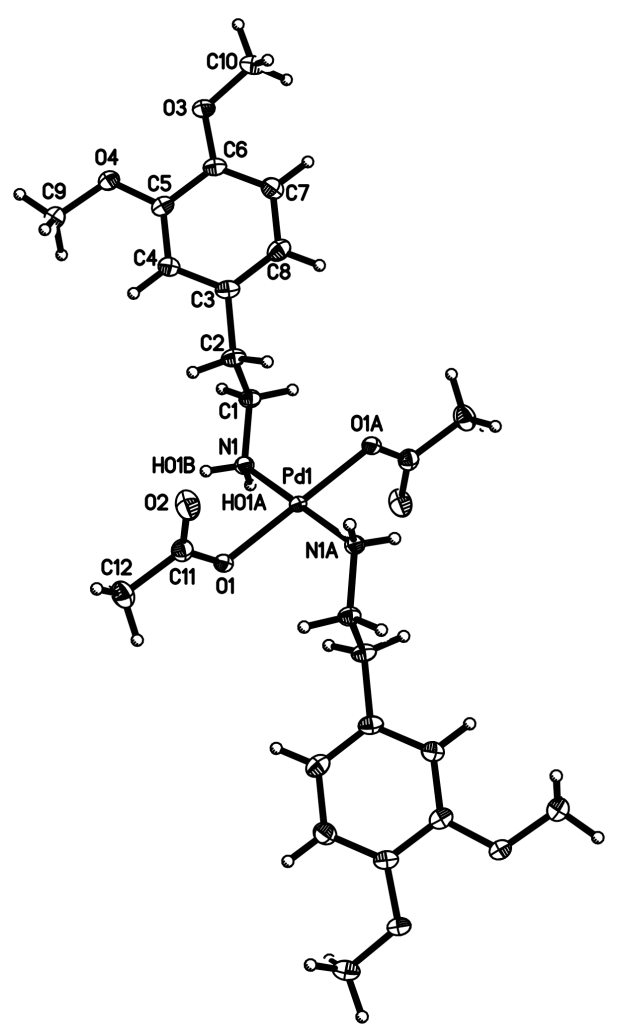

Figure 4. X-ray thermal ellipsoid plot of complex $\mathbf{6 b - O A c} \cdot \mathrm{H}_{2} \mathrm{O}(50 \%$ probability) showing the labeling scheme (the solvent molecule has been omitted for clarity). Selected bond lengths ( $)$ and angles (deg): $\mathrm{Pd}(1)-\mathrm{N}(1)=2.0451(17), \mathrm{Pd}(1)-\mathrm{O}(1)=2.0161(14) ; \mathrm{N}(1)-\mathrm{Pd}(1)-\mathrm{O}(1)=86.83(7), \mathrm{N}(1)-\mathrm{Pd}(1)-\mathrm{O}(1 \mathrm{~A})=$ 93.17(7). 


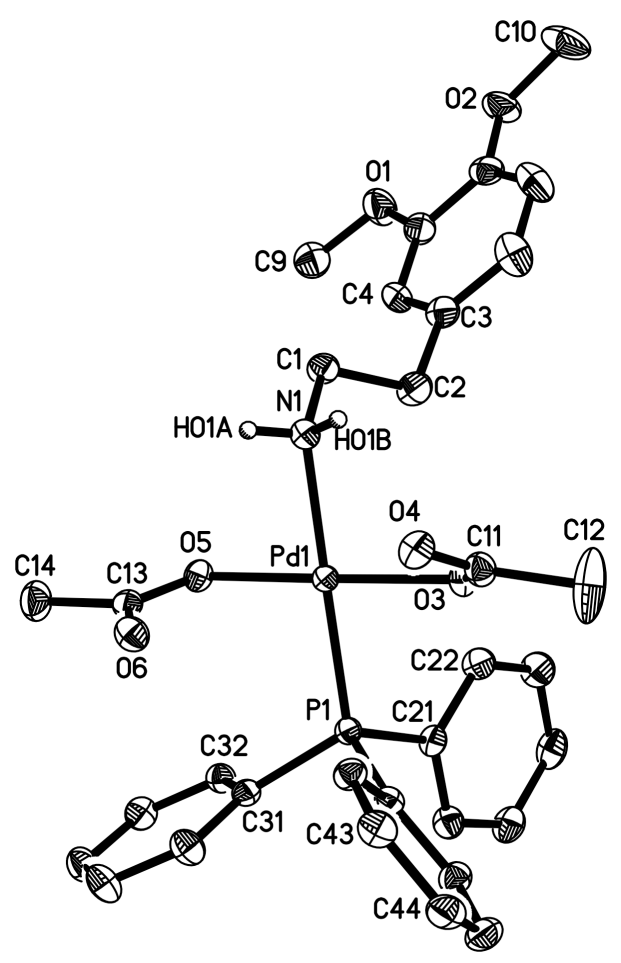

Figure 5. X-ray thermal ellipsoid plot of complex 7b-OAc (50\% probability) showing the labeling scheme (hydrogen atoms bonded to carbon have been omitted for clarity). Selected bond lengths (Å) and angles $(\mathrm{deg}): \mathrm{Pd}(1)-\mathrm{N}(1)=2.1000(14), \mathrm{Pd}(1)-\mathrm{O}(3)=2.0234(11), \operatorname{Pd}(1)-\mathrm{P}(1)=2.2539(4), \operatorname{Pd}(1)-$ $\mathrm{O}(5)=2.0042(11) ; \mathrm{N}(1)-\mathrm{Pd}(1)-\mathrm{O}(3)=92.77(5), \mathrm{O}(3)-\mathrm{Pd}(1)-\mathrm{P}(1)=86.20(3), \mathrm{P}(1)-\mathrm{Pd}(1)-\mathrm{O}(5)=$ 93.24(3), $\mathrm{O}(5)-\mathrm{Pd}(1)-\mathrm{N}(1)=87.89(5)$.

\section{On the Synthesis of Ortho-Palladated Derivatives of Homoveratrylamine by Oxidative} Addition. As we were not able to obtain the ortho-palladated derivative of homoveratrylamine at $\mathrm{C} 2$ position by $\mathrm{C}-\mathrm{H}$ activation, we tried to prepare it by oxidative addition of 2-bromo-3,4dimethoxyphenethylamine (see Experimental Section and Supporting Information) to "Pd(dba) ${ }_{2}$ " $\left(\left[\mathrm{Pd}_{2}(\mathrm{dba})_{3}\right] \cdot \mathrm{dba} ; \mathrm{dba}=\right.$ dibenzylideneacetone $)$ in the presence of tmeda (tmeda $=N, N, N^{\prime}, N^{\prime}-$ tetramethylethylenediamine). When these three reagents (molar ratio $=1: 1: 1$ ) were stirred in dry toluene, at room temperature, for $24 \mathrm{~h}$, a mixture was obtained from which no pure complex could be isolated. Addition of $\mathrm{PPh}_{3}$ to this mixture afforded a new mixture of at least five P-containing compounds, as observed by ${ }^{31} \mathrm{P}$ NMR, that could not be separated (Scheme 6). When an analogous reaction was carried out from 6-bromo-3,4-dimethoxyphenethylamine, the complex $[\operatorname{Pd}\{C, N$ - 
$\left.\mathrm{C}_{6} \mathrm{H}_{2} \mathrm{CH}_{2} \mathrm{CH}_{2} \mathrm{NH}_{2}-6,(\mathrm{OMe})_{2}-3,4\right\}$ (tmeda) $] \mathrm{Br}$ (9b) precipitated in the reaction medium and could be isolated in a $72 \%$ yield (Scheme 6). Reaction of $\mathbf{9 b}$ with $\mathrm{PPh}_{3}($ molar ratio $=1: 1)$ gave complex $\mathbf{3 b}-\mathbf{B r}$.

The oxidative addition of 2-bromo-3,4-dimethoxyphenethylamine to " $\mathrm{Pd}(\mathrm{dba})_{2}$ " was tried under nitrogen atmosphere using other solvents, temperatures and in the presence or absence of auxiliary ligands, but no satisfactory results were obtained. For instance, when the reaction was carried out (1) in the absence of any auxiliary ligand, in toluene, at $25-60{ }^{\circ} \mathrm{C}$, unreacted starting material was obtained, along with other unidentified compounds, and (2) in presence of ethylenediamine and $\mathrm{NaBr}$, in $\mathrm{THF}$, at room temperature, abundant decomposition to metallic palladium was observed.

Scheme 6. Oxidative Addition of 2- and 6-Bromo-3,4-dimethoxyphenethylamine to $\mathrm{Pd}(\mathrm{dba})_{2}$
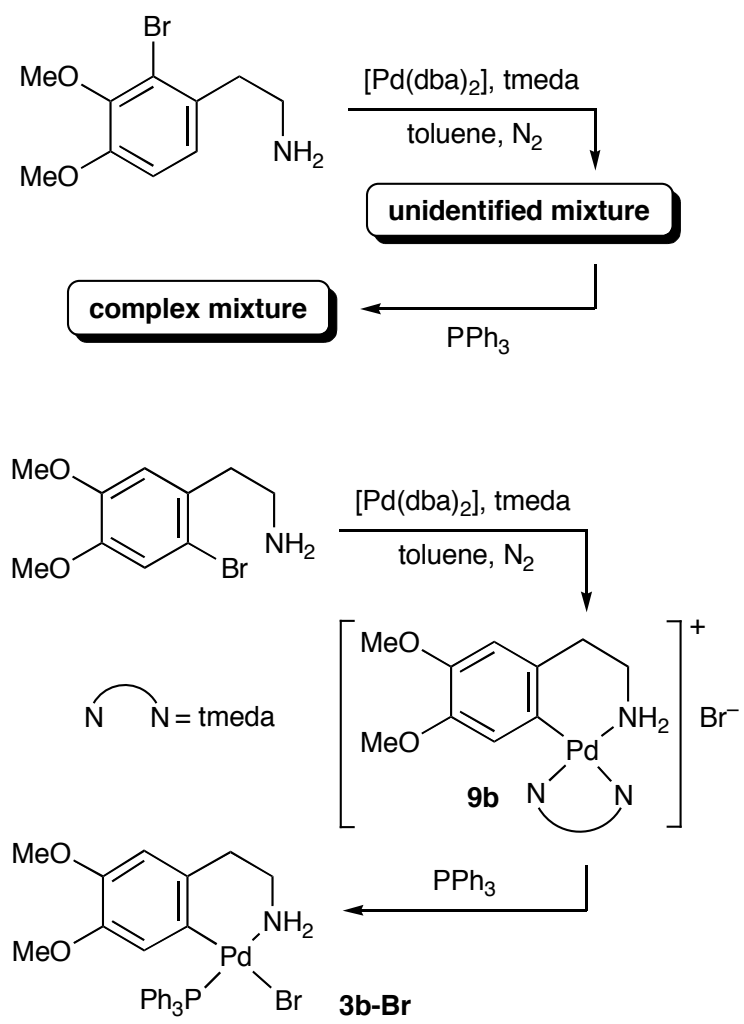

On the Ortho-Palladation of L-Tyrosine Methyl Ester. To check the advantages of using the triflate salt instead of the free amino acid derivative, we tried the reaction of L-tyrosine methyl ester with one equiv of $\mathrm{Pd}(\mathrm{OAc})_{2}$ in acetonitrile at $78^{\circ} \mathrm{C}$ for $8 \mathrm{~h}$. In these conditions, a dark brown solid $(\mathbf{Z})$

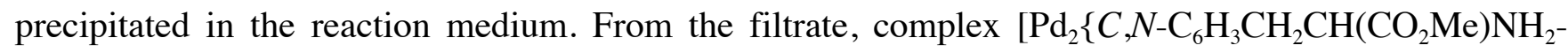
$\left.2,(\mathrm{OH})-4\}_{2}(\mu \text {-OAc })_{2}\right](\mathbf{1 a - O A c})$ was isolated in a $15 \%$ yield (Scheme 7$)$. 
$\mathbf{Z}$ is very insoluble in all common organic solvents, including acetonitrile and DMSO, which prevented the removal of the metallic palladium that contaminated it. Its elemental analysis detected C, $\mathrm{H}$ and $\mathrm{N}$ and its IR spectrum showed a strong peak corresponding to the $v_{\text {sym }}\left(\mathrm{CO}_{2}\right)$ at $1724 \mathrm{~cm}^{-1} . \mathbf{Z}$ did not react with $\mathrm{PPh}_{3}$ or pyridine, even when heated at $80{ }^{\circ} \mathrm{C}$ in acetonitrile. When treated with XyNC or ${ }^{t} \mathrm{BuNC}$ very complex mixtures were obtained, which showed in their ${ }^{1} \mathrm{H}$ NMR signals attributable to several types of isocyanide molecules. When $\mathbf{Z}$ was reacted with triflic acid, a deep-red solution formed, from which an oily residue was obtained, the ${ }^{1} \mathrm{H}$ NMR of which showed, in the aromatic region, the signals corresponding to an ortho-palladated ring, along with other unidentified product. All our efforts to obtain a solid from this residue were fruitless. In one of these attempts the residue was repeatedly washed with $\mathrm{Et}_{2} \mathrm{O}$. An X-ray diffraction study of a single crystal obtained from the combined extracts, showed it to be Ia-2MeCN (Figure 6), the solvento-complex proposed as an intermediate in the orthopalladation reaction when the triflate salt is used as starting material (Scheme 2; $\mathrm{S}=\mathrm{MeCN}$ ). Finally, when complex 1a-OAc was stirred in acetonitrile for 18-36 h, the solid $\mathbf{Z}$ formed and acetic acid could be detected in the reaction mixture. Based on all these data, we conclude that $\mathbf{Z}$ is mainly a polymeric complex (Scheme 7), derived from 1a-OAc.

Scheme 7. Ortho-Palladation of L-Tyrosine Methyl Ester 

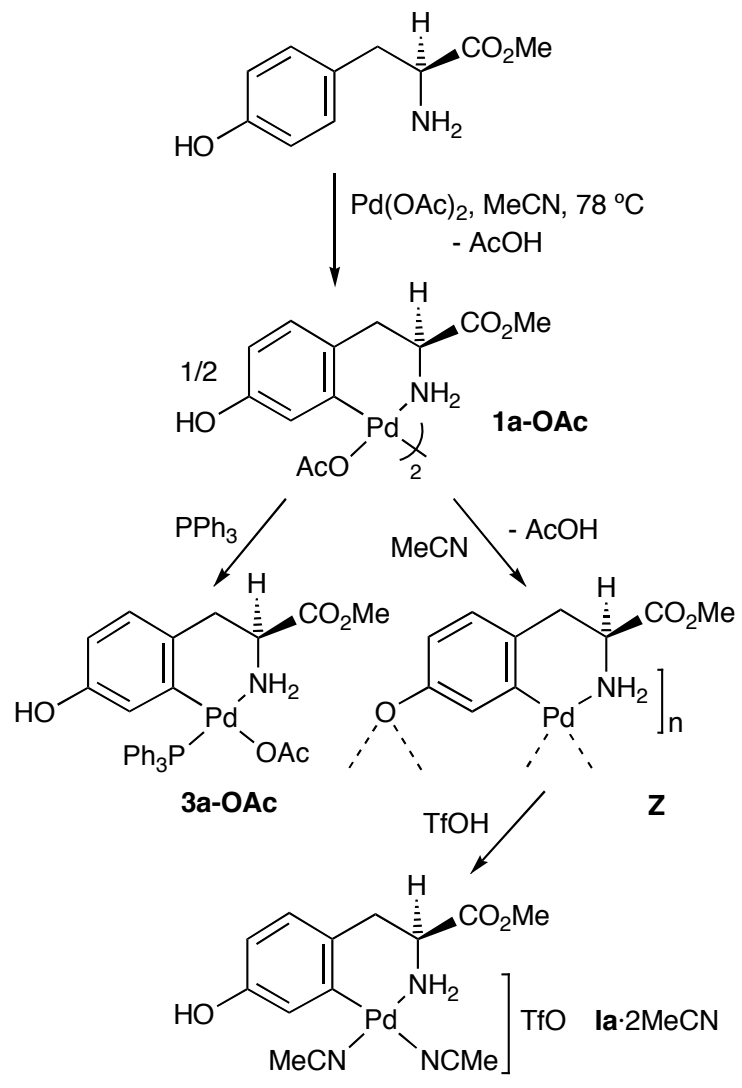

The formation of polymer $\mathbf{Z}$ can be partially eluded by changing the reaction conditions. The lowest yield (29\%) of $\mathbf{Z}$ was reached when a 1:1 mixture of L-tyrosine methyl ester and $\mathrm{Pd}(\mathrm{OAc})_{2}$ was stirred in $\mathrm{CH}_{2} \mathrm{Cl}_{2}$ at room temperature for $4 \mathrm{~h}$, the solvent was removed, acetonitrile was added, and the solution heated at $70{ }^{\circ} \mathrm{C}$ for $2.5 \mathrm{~h}$. In these conditions, complex 1a-OAc was obtained in $63 \%$ yield. When longer heating times or higher temperatures were used, the yield of $\mathbf{Z}$ increased. Contrarily, if the ortho-palladation reaction was carried out in the presence of 2 equiv of HOAc, the amount of polymer $\mathbf{Z}$ decreased to $10 \%$, and when 3 equiv of HOAc were used, formation of $\mathbf{Z}$ was not observed. In a similar way, when the triflate $\mathbf{A}$ was used as starting material, two equivalents of HOAc were generated during the ortho-palladation reaction (Scheme 2) preventing the deprotonation of the $\mathrm{OH}$ group and the formation of $\mathbf{Z}$. Complex 1a-OAc reacted with $\mathrm{PPh}_{3}$ in a 1:2 molar ratio to give the mononuclear phosphino adduct $\left[\mathrm{Pd}\left\{C, N-\mathrm{C}_{6} \mathrm{H}_{3} \mathrm{CH}_{2} \mathrm{CH}\left(\mathrm{CO}_{2} \mathrm{Me}\right) \mathrm{NH}_{2}-2,(\mathrm{OH})-4\right\}(\mathrm{OAc}) \mathrm{PPh}_{3}\right]($ 3a-OAc; Scheme 7$)$. 


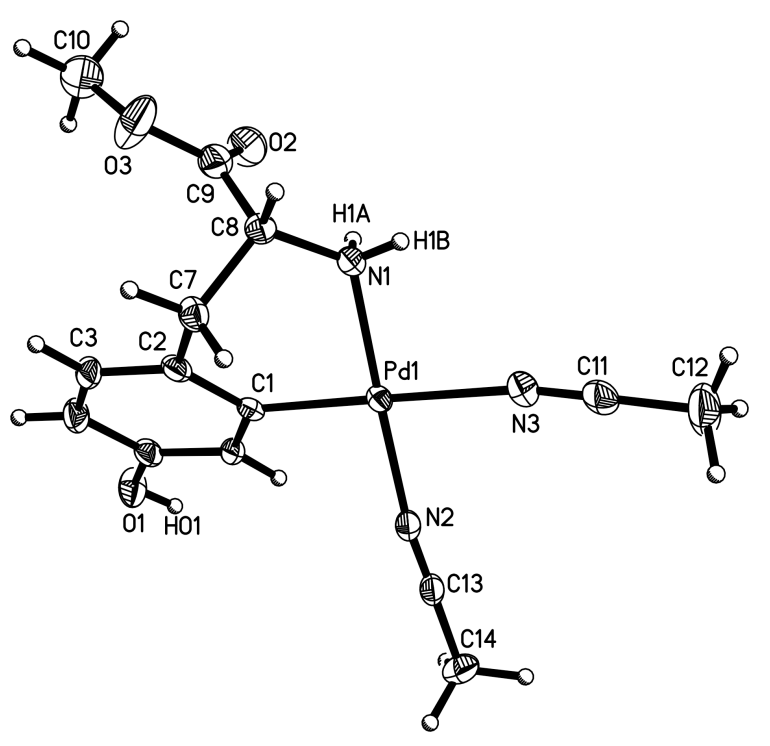

Figure 6. X-ray thermal ellipsoid plot of the cation of intermediate Ia $2 \mathrm{MeCN}$ (50\% probability) showing the labeling scheme. Selected bond lengths $(\AA)$ and angles $(\mathrm{deg})$ : $\operatorname{Pd}(1)-C(1)=1.979(4)$, $\mathrm{Pd}(1)-\mathrm{N}(1)=2.044(4), \operatorname{Pd}(1)-\mathrm{N}(2)=2.008(4), \operatorname{Pd}(1)-\mathrm{N}(3)=2.143(4) ; \mathrm{C}(1)-\mathrm{Pd}(1)-\mathrm{N}(1)=87.77(16)$, $\mathrm{N}(1)-\mathrm{Pd}(1)-\mathrm{N}(3)=92.39(15), \mathrm{N}(3)-\mathrm{Pd}(1)-\mathrm{N}(2)=88.35(15), \mathrm{N}(2)-\mathrm{Pd}(1)-\mathrm{C}(1)=91.64(16), \operatorname{Pd}(1)-$ $\mathrm{N}(2)-\mathrm{C}(13)=171.6(4), \operatorname{Pd}(1)-\mathrm{N}(3)-\mathrm{C}(11)=170.3(4)$.

The crystal structures of intermediate Ia-2MeCN (Figure 6) and complex 3a-OAc (Figure 7) have been determined by X-ray diffraction studies and they show the palladium atom in a slightly-distorted square-planar environment (mean deviation: $0.0552 \AA$, Ia-2MeCN; $0.0332 \AA$, 3a-OAc) with dihedral angles of $5.7^{\circ}(\mathbf{I a} \cdot 2 \mathrm{MeCN})$ and $4.2^{\circ}$ (3a-OAc) between the $\mathrm{N}(1)-\mathrm{Pd}(1)-\mathrm{C}(1)$ and $\mathrm{N}(2)-\mathrm{Pd}(1)-\mathrm{N}(3)$ planes $(\mathbf{I a} \cdot 2 \mathrm{MeCN})$ and the $\mathrm{N}(1)-\mathrm{Pd}(1)-\mathrm{C}(1)$ and $\mathrm{P}(1)-\mathrm{Pd}(1)-\mathrm{O}(4)$ planes (3a-OAc). In both complexes, the chelating amino ligand forms a six-membered metallacycle with a boat conformation. These structural features are similar to those of analogous complexes containing primary orthopalladated phenethylamines. ${ }^{8,17-19,46}$ In complex 3a-OAc, the phosphine and the amino group are mutually trans, according to the previously mentioned transphobia between the P/Ar pair of ligands.

Surprisingly, the X-ray crystallographic studies do not reveal the $(S)$ absolute configuration of the $\alpha$ carbon stereocenter in complexes Ia-2MeCN and 3a-OAc. As we consider discardable the racemization of the amine during the ortho-palladation reaction, the single crystal used in the diffraction study must 
correspond to a racemic mixture of our products plus those formed from the small amount of the $(R)$ enantiomer present in the starting material (L-tyrosine methyl ester of 98\%). In fact, the crystals suitable for X-ray diffraction studies were obtained in very low yield.

Otra alternativa:

Surprisingly, the X-ray crystallographic studies of complexes Ia-2MeCN and 3a-OAc correspond to a racemic mixture, which must arise from the co-crystallization of the $(S)$-products with those formed from the small amount of the $(R)$ enantiomer present in the starting material (L-tyrosine methyl ester of 98\%). In fact, the crystals suitable for X-ray diffraction studies were obtained in very low yield.

For complex Ia $2 \mathrm{MeCN}$, the cationic units are connected to the triflate groups through classical and non-classical hydrogen bonds, generating double chains along the $a$ axis. For complex 3a-OAc, two adjacent molecules are associated through two hydrogen bonds, both of them involving the OH group, giving rise to dimers, which in turn are associated through non-classical hydrogen interactions (involving also the $\mathrm{OH}$ group), generating double chains along the $b$ axis (see Supporting Information).

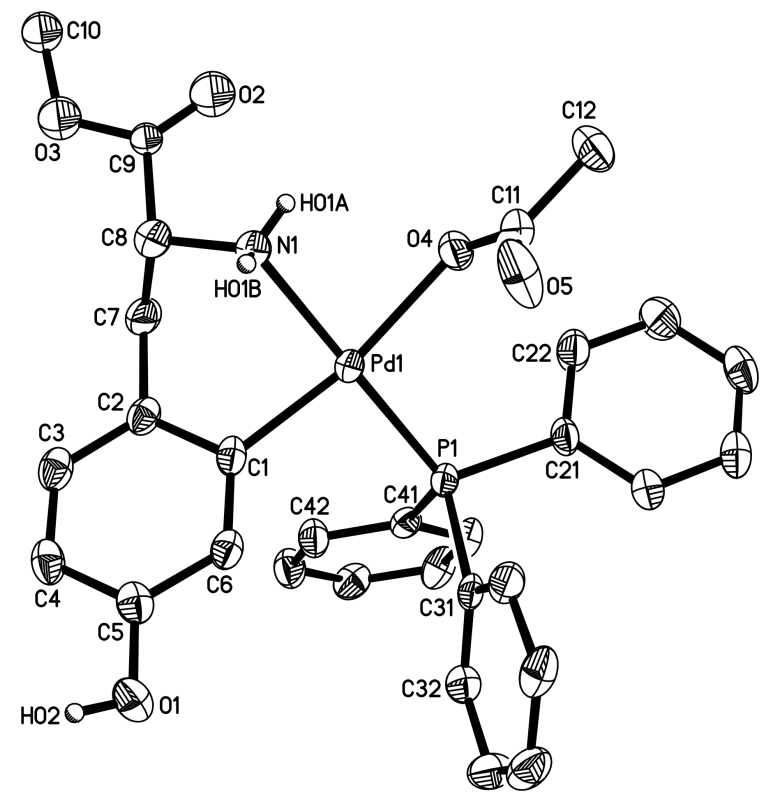

Figure 7. X-ray thermal ellipsoid plot of complex 3a-OAc (50\% probability) showing the labeling scheme. Selected bond lengths $(\AA)$ and angles $(\mathrm{deg})$ : $\mathrm{Pd}(1)-\mathrm{C}(1)=2.001(3), \operatorname{Pd}(1)-\mathrm{N}(1)=2.120(2)$, $\mathrm{Pd}(1)-\mathrm{O}(4)=2.119(2), \mathrm{Pd}(1)-\mathrm{P}(1)=2.2500(10) ; \mathrm{C}(1)-\mathrm{Pd}(1)-\mathrm{N}(1)=86.83(10), \mathrm{N}(1)-\mathrm{Pd}(1)-\mathrm{O}(4)=$ 82.66(9), O(4)-Pd(1)-P(1) = 96.72(6), $\mathrm{P}(1)-\mathrm{Pd}(1)-\mathrm{C}(1)=93.73(8)$. 


\section{Synthesis of Lactams by Insertion of Carbon Monoxide into the Pd-C Bond of Cyclopalladated}

Complexes. The insertion of $\mathrm{CO}$ into the $\mathrm{Pd}-\mathrm{C}$ bond of ortho-palladated benzyl or phenethylamines is a well-known process, , $3,31,47$ which constitutes the key step in the $\mathrm{Pd}(\mathrm{II})$-catalyzed carbonylation of $N$ protected arylalkylamines via $\mathrm{C}-\mathrm{H}$ aryl activation, to give lactams or esters. ${ }^{48,49}$

However, with the notably exception of a few $\alpha$-alkyl-substituted phenethylamines ${ }^{50}$ the catalytic cycle seems to fail for primary arylalkylamines. ${ }^{49}$ This result is not surprising since ortho-palladation of primary benzyl or phenethylamines does not occur (or it is extremely slow) when an excess of the amine is present. ${ }^{14,15,17}$ Although catalytic conversion is not generally achieved, primary arylalkylamines could be converted to benzolactams through an stoichiometric process. ${ }^{8,9,11,51}$

The reaction of complexes $\mathbf{1 a}-\mathbf{B r}$ or $\mathbf{1 b}-\mathbf{B r}$ with $\mathrm{CO}$ in $\mathrm{CH}_{2} \mathrm{Cl}_{2}$ at room temperature gave palladium(0) and the lactam 10a or $\mathbf{1 0 b}$ (Scheme 8). Previous reports on the synthesis of compound 10b, a natural alkaloid known as corydaldine ${ }^{52,53}$ involved drastic reaction conditions or moisture sensitive reagents. ${ }^{54}$ Scheme 8. Synthesis of Lactams 10a and 10b

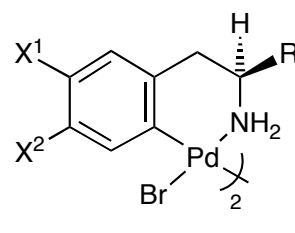

\begin{tabular}{|l|lll|}
\hline & $\mathrm{R}$ & $\mathrm{X}^{1}$ & $\mathrm{X}^{2}$ \\
\hline $\mathbf{1 a}-\mathrm{Br}$ & $\mathrm{CO}_{2} \mathrm{Me}$ & $\mathrm{H}$ & $\mathrm{OH}$ \\
$\mathbf{1 b}-\mathrm{Br}$ & $\mathrm{H}$ & $\mathrm{OMe}$ & $\mathrm{OMe}$ \\
\hline
\end{tabular}

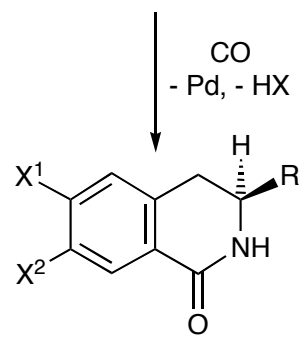

\begin{tabular}{|l|lll|}
\hline & $\mathrm{R}$ & $\mathrm{X}^{1}$ & $\mathrm{X}^{2}$ \\
\hline $10 \mathrm{a}$ & $\mathrm{CO}_{2} \mathrm{Me}$ & $\mathrm{H}$ & $\mathrm{OH}$ \\
$10 \mathrm{~b}$ & $\mathrm{H}$ & $\mathrm{OMe}$ & $\mathrm{OMe}$ \\
\hline
\end{tabular}

\section{EXPERIMENTAL SECTION}

Caution! Special precautions should be taken in handling thallium(I) compounds, which are toxic. Also, perchlorate salts of organic cations may be explosive. Preparations on a larger scale than that reported herein should be avoided.

General procedures. Infrared spectra were recorded in the range $4000-200 \mathrm{~cm}^{-1}$ on a Perkin Elmer 16F-PC-FT spectrometer, using Nujol mulls between polyethylene sheets. Conductivities in acetone 
were measured with a Crison Micro CM2200 conductimeter. Melting points were determined on a Reichert apparatus and are uncorrected. C, H, N and S analyses were carried out with a Carlo Erba 1106 microanalyzer. Specific optical rotations were measured in a $1 \mathrm{dm}$ thermostated quartz cell on a JascoP1020 polarimeter. Unless otherwise stated, NMR spectra were recorded in $\mathrm{CDCl}_{3}$ in $\mathrm{Bruker}^{\mathrm{Avance}}$ 200, 300 or 400 spectrometers. Chemical shifts are referenced to TMS $\left({ }^{1} \mathrm{H}\right.$ and $\left.{ }^{13} \mathrm{C}\left\{{ }^{1} \mathrm{H}\right\}\right)$ or $\mathrm{H}_{3} \mathrm{PO}_{4}$ $\left({ }^{31} \mathrm{P}\left\{{ }^{1} \mathrm{H}\right\}\right)$. Signals in the ${ }^{1} \mathrm{H}$ and ${ }^{13} \mathrm{C}$ NMR spectra of all complexes were assigned with the help of APT, HMQC and HMBC techniques. Reactions were carried out at room temperature without special precautions against moisture, unless otherwise indicated.

L-Tyrosine methyl ester, 3,4-dimethoxyphenethylamine (homoveratrylamine), trifluoromethanesulfonic acid (triflic acid), $\mathrm{AgClO}_{4}$ (Aldrich), XyNC, $\mathrm{PPh}_{3}, \mathrm{P}(p-\mathrm{To})_{3}, N, N, N^{\prime}, N^{\prime}-$ tetramethylethylenediamine (tmeda; Fluka), CO (Air Products), NaBr (Scharlau), NaOAc (Sigma), and $\mathrm{Pd}(\mathrm{OAc})_{2}$ (Johnson Matthey) were used as received. $[\mathrm{Tl}(\mathrm{acac})]^{55}$ (Hacac $=$ acetylacetone) and $\left[\mathrm{Pd}_{2}(\mathrm{dba})_{3}\right] \cdot \mathrm{dba}^{56}$ were prepared according to published procedures. 2-(2-Bromo-3,4dimethoxyphenyl)ethanamine has been prepared according to the method reported by Weinstock. et al., ${ }^{57}$ but using a solution $1 \mathrm{M}$ of $\mathrm{BH}_{3}$ in THF instead of $\mathrm{B}_{2} \mathrm{H}_{6}$ in the last step. Chart 1 gives the numbering scheme for the free ligands, the palladacycles and the tetrahydroisoquinolones.

Most complexes containing ortho-palladated homoveratrylamine are obtained as hydrates. Only for complex 6b-OAc $\cdot \mathrm{H}_{2} \mathrm{O}$, the crystallization water can be removed by heating the sample at $60{ }^{\circ} \mathrm{C}$ for $2 \mathrm{~h}$ in a vacuum oven. Likely, the water molecules are connected through hydrogen interactions with the OMe or the OAc groups of the complexes, in a stronger way than that observed in the crystal structure of complex 6b-OAc $\cdot \mathrm{H}_{2} \mathrm{O}$ (see Supporting Information).

Chart 1. Numbering Schemes for the Free Ligands, the Ortho-Palladated Palladacycles and the Tetrahydroisoquinolones. ${ }^{\mathrm{a}}$ 


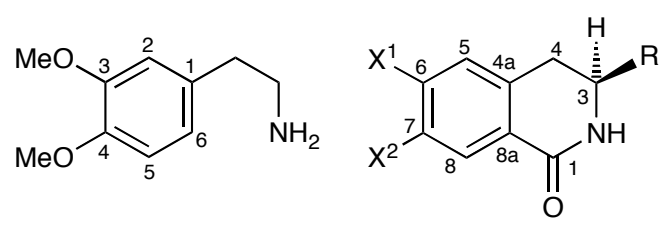

${ }^{a}$ For the convenience of the reader, the notation of the free homoveratrylamine ligand is maintained in the ortho-palladated complexes.

Synthesis of (S)-[4-(OH)- $\left.\mathrm{C}_{6} \mathrm{H}_{4} \mathrm{CH}_{2} \mathrm{CH}\left(\mathrm{CO}_{2} \mathrm{Me}\right) \mathrm{NH}_{3}\right] \mathrm{OTf}(\mathrm{A})$. Triflic acid (0.8 $\mathrm{mL}$ of a solution containing $11.3 \mathrm{mmol} / \mathrm{mL}, 9.04 \mathrm{mmol}$ ) was slowly added to a solution of L-tyrosine methyl ester (500 $\mathrm{mg}, 2.56 \mathrm{mmol})$ in $\mathrm{Et}_{2} \mathrm{O}(50 \mathrm{~mL})$, and the resulting white suspension was vigorously stirred for $20 \mathrm{~min}$. The mixture was filtered, and the solid was washed with $\mathrm{Et}_{2} \mathrm{O}(3 \times 5 \mathrm{~mL})$ and air-dried to give compound A as a white solid. Yield: $731 \mathrm{mg}, 2.12 \mathrm{mmol}, 83 \%$. Mp: $85^{\circ} \mathrm{C} . \Lambda_{\mathrm{M}}\left(\Omega^{-1} \mathrm{~cm}^{2} \mathrm{~mol}^{-1}\right)=70$ (4.98 x 10 $\left.{ }^{-4} \mathrm{M}\right)$. Anal. Calcd for $\mathrm{C}_{11} \mathrm{H}_{14} \mathrm{~F}_{3} \mathrm{NO}_{6} \mathrm{~S}$ (345.292): C, 38.26; H, 4.09; N, 4.06; S, 9.29. Found: C, 38.50; H, 4.60; N, 4.13; S, 8.98. IR (cm $\left.{ }^{-1}\right): v(\mathrm{OH}) 3592 \mathrm{~s} ; v(\mathrm{NH}) 3353 \mathrm{~s} ; v(\mathrm{CO}) 1737 \mathrm{~s} .{ }^{1} \mathrm{H}$ NMR $(300.1$ $\left.\mathrm{MHz}, \mathrm{DMSO}-d_{6}\right): \delta 2.91\left(\mathrm{~d}, 2 \mathrm{H}, \mathrm{CH}_{2},{ }^{3} J_{\mathrm{HH}}=5.7 \mathrm{~Hz}\right), 3.66(\mathrm{~s}, 3 \mathrm{H}, \mathrm{OMe}), 4.08\left(\right.$ t $\mathrm{t}$ ", $1 \mathrm{H}, \mathrm{CH},{ }^{3} J_{\mathrm{HH}}=6.0$ $\mathrm{Hz}), 6.70\left(\mathrm{~d}, 2 \mathrm{H}, m-\mathrm{H}, \mathrm{C}_{6} \mathrm{H}_{4},{ }^{3} J_{\mathrm{HH}}=7.8 \mathrm{~Hz}\right), 6.98\left(\mathrm{~d}, 2 \mathrm{H}, o-\mathrm{H}, \mathrm{C}_{6} \mathrm{H}_{4},{ }^{3} J_{\mathrm{HH}}=7.8 \mathrm{~Hz}\right)$. The $\mathrm{OH}$ and $\mathrm{NH}_{3}$ resonances were not observed. ${ }^{13} \mathrm{C}$ NMR $\left(75.45 \mathrm{MHz}, \mathrm{DMSO}-d_{6}\right): \delta 36.4\left(\mathrm{~s}, \mathrm{CH}_{2}\right), 52.4(\mathrm{~s}, \mathrm{OMe}), 54.0$ $(\mathrm{s}, \mathrm{CH}), 115.4\left(\mathrm{~s}, m-\mathrm{CH}, \mathrm{C}_{6} \mathrm{H}_{4}\right), 120.7\left(\mathrm{q}, \mathrm{CF}_{3},{ }^{1} J_{\mathrm{CF}}=324.4 \mathrm{~Hz}\right), 125.1(\mathrm{~s}, i-\mathrm{C}), 130.4\left(\mathrm{~s}, o-\mathrm{CH}_{6} \mathrm{C}_{6} \mathrm{H}_{4}\right)$, $156.6(\mathrm{~s}, \mathrm{C}-\mathrm{OH}), 170.9(\mathrm{~s}, \mathrm{CO}) .(+) \mathrm{ESI}-\mathrm{MS} m / z$ 91.1, 136.1, $179.1\left[\left(\mathrm{M}-\mathrm{OH}-\mathrm{CF}_{3} \mathrm{SO}_{3}\right)^{+}\right], 196.1[(\mathrm{M}-$ $\left.\left.\mathrm{CF}_{3} \mathrm{SO}_{3}\right)^{+}\right], 218.1\left[\left(\mathrm{M}-\mathrm{H}-\mathrm{CF}_{3} \mathrm{SO}_{3}+\mathrm{Na}\right)^{+}\right] .(-)$ESI-MS $m / z 149.0\left(\mathrm{CF}_{3} \mathrm{SO}_{3}{ }^{-}\right)$. (+)ESI-HRMS: exact mass calcd for $\mathrm{C}_{10} \mathrm{H}_{14} \mathrm{NO}_{3} 196.0974\left[\left(\mathrm{M}-\mathrm{CF}_{3} \mathrm{SO}_{3}\right)^{+}\right]$; found 196.0971. $[\alpha]_{\mathrm{D}}{ }^{20}=+13.69(\mathrm{c}=0.20$, $\mathrm{MeOH})$.

Synthesis of [3,4-(MeO) $\left.)_{2} \mathrm{C}_{6} \mathrm{H}_{3} \mathrm{CH}_{2} \mathrm{CH}_{2} \mathrm{NH}_{3}\right]$ OTf (B). Triflic acid (0.8 $\mathrm{mL}$ of a solution containing $11.3 \mathrm{mmol} / \mathrm{mL}, 9.04 \mathrm{mmol})$ was slowly added to a solution of homoveratrylamine $(1 \mathrm{~mL}, 6.02 \mathrm{mmol})$ in $\mathrm{Et}_{2} \mathrm{O}(50 \mathrm{~mL})$, and the resulting white suspension was vigorously stirred for $20 \mathrm{~min}$. The mixture was filtered, and the solid was washed with $\mathrm{Et}_{2} \mathrm{O}(3 \times 5 \mathrm{~mL})$ and air-dried to give compound $\mathbf{B}$ as a white solid. Yield: $1.61 \mathrm{~g}, 4.87 \mathrm{mmol}, 81 \%$. Mp: $99{ }^{\circ} \mathrm{C} . \Lambda_{\mathrm{M}}\left(\Omega^{-1} \mathrm{~cm}^{2} \mathrm{~mol}^{-1}\right)=95\left(5.22 \times 10^{-4} \mathrm{M}\right)$. Anal. Calcd for $\mathrm{C}_{11} \mathrm{H}_{16} \mathrm{~F}_{3} \mathrm{NO}_{5} \mathrm{~S}$ (331.309): C, 39.88; H, 4.87; N, 4.23; S, 9.68. Found: C, 40.02; H, 4.50; N, 4.27; S, 
9.50. IR $\left(\mathrm{cm}^{-1}\right): v(\mathrm{NH}) 3243$ br m, 3158 br m, 3078 br m. ${ }^{1} \mathrm{H}$ NMR (400.91 MHz, DMSO- $\left.d_{6}\right): \delta 2.77$

(“t”, $\left.2 \mathrm{H}, \mathrm{CH}_{2} \mathrm{Ar},{ }^{3} J_{\mathrm{HH}}=8.0 \mathrm{~Hz}\right), 3.02$ (“t”, $\left.2 \mathrm{H}, \mathrm{CH}_{2} \mathrm{~N},{ }^{3} J_{\mathrm{HH}}=8.0 \mathrm{~Hz}\right), 3.71(\mathrm{~s}, 3 \mathrm{H}, \mathrm{OMe}), 3.74$ (s, $3 \mathrm{H}$, $\mathrm{OMe}), 6.75\left(\mathrm{dd}, 1 \mathrm{H}, \mathrm{H} 6,{ }^{3} J_{\mathrm{HH}}=8.0,{ }^{4} J_{\mathrm{HH}}=2.0 \mathrm{~Hz}\right), 6.84\left(\mathrm{~d}, 1 \mathrm{H}, \mathrm{H} 2,{ }^{4} J_{\mathrm{HH}}=2.0 \mathrm{~Hz}\right), 6.89(\mathrm{~d}, 1 \mathrm{H}, \mathrm{H} 5$, $\left.{ }^{3} J_{\mathrm{HH}}=8.4 \mathrm{~Hz}\right), 7.61\left(\right.$ br s, $\left.3 \mathrm{H}, \mathrm{NH}_{3}\right) .{ }^{13} \mathrm{C} \mathrm{NMR}\left(100.81 \mathrm{MHz}, \mathrm{DMSO}-d_{6}\right): \delta 32.7\left(\mathrm{~s}, \mathrm{CH}_{2} \mathrm{Ar}\right), 40.2(\mathrm{~s}$, $\left.\mathrm{CH}_{2} \mathrm{~N}\right), 55.4(\mathrm{~s}, \mathrm{OMe}), 55.5$ (s, OMe), 112.1 (s, CH, C5), 112.6 (s, CH, C2), 120.6 (s, CH, C6), 129.5 (s, C1), 147.7 (s, C4, COMe), 148.8 (s, C3, COMe). The ${ }^{13} \mathrm{C}$ signal corresponding to the OTf group was not observed. (+)ESI-MS $m / z$ 165.1, $182.1\left[\left(\mathrm{M}-\mathrm{CF}_{3} \mathrm{SO}_{3}\right)^{+}\right], 204.1\left[\left(\mathrm{M}-\mathrm{H}-\mathrm{CF}_{3} \mathrm{SO}_{3}+\mathrm{Na}\right)^{+}\right]$. (-)ESIMS m/z $149.0\left(\mathrm{CF}_{3} \mathrm{SO}_{3}^{-}\right), 480.0\left[\left(\mathrm{M}+\mathrm{CF}_{3} \mathrm{SO}_{3}\right)^{-}\right]$. (+)ESI-HRMS: exact mass calcd for $\mathrm{C}_{10} \mathrm{H}_{16} \mathrm{NO}_{2}$ 182.1181 [(M - $\left.\left.\mathrm{CF}_{3} \mathrm{SO}_{3}\right)^{+}\right]$; found 182.1183.

\section{Synthesis of $(S, S)-\left[\mathrm{Pd}_{2}\left\{C, N-\mathrm{C}_{6} \mathrm{H}_{3} \mathrm{CH}_{2} \mathrm{CH}\left(\mathrm{CO}_{2} \mathrm{Me}\right) \mathrm{NH}_{2}-2,(\mathrm{OH})-4\right\}_{2}(\mu-\mathrm{Br})_{2}\right] \quad(1 \mathrm{a}-\mathrm{Br}) . \quad$ The} ammonium triflate $\mathbf{A}(800 \mathrm{mg}, 2.32 \mathrm{mmol})$ was added to a suspension of $\mathrm{Pd}(\mathrm{OAc})_{2}(520 \mathrm{mg}, 2.32$ mmol) in acetonitrile $(50 \mathrm{~mL})$, and the resulting solution was heated at $60{ }^{\circ} \mathrm{C}$ for $1 \mathrm{~h}$ and then at $78{ }^{\circ} \mathrm{C}$ for $4 \mathrm{~h}$. The mixture was filtered through a plug of Celite, the solution was concentrated to dryness, acetone $(40 \mathrm{~mL})$ and $\mathrm{NaBr}(1 \mathrm{~g}, 9.72 \mathrm{mmol})$ were added, and the suspension was stirred for $12 \mathrm{~h}$. The solvent was removed, and $\mathrm{CH}_{2} \mathrm{Cl}_{2}(40 \mathrm{~mL})$ was added. The suspension was filtered, and the solid was washed with $\mathrm{H}_{2} \mathrm{O}(2 \times 5 \mathrm{~mL})$ and $\mathrm{Et}_{2} \mathrm{O}(2 \times 5 \mathrm{~mL})$, and air-dried to give a first crop of complex 1a-Br (570 mg). The $\mathrm{Et}_{2} \mathrm{O}$ washing was concentrated to ca. $2 \mathrm{~mL}$, and $n$-pentane $(30 \mathrm{~mL})$ was added. The suspension was filtered, and the solid was washed with $n$-pentane $(2 \times 5 \mathrm{~mL})$ to give a second crop of complex 1a-Br as an orange solid (71 mg). Yield: $641 \mathrm{mg}, 0.84 \mathrm{mmol}, 73 \%$. Mp: $202{ }^{\circ} \mathrm{C}$. Anal. Calcd for $\mathrm{C}_{20} \mathrm{H}_{24} \mathrm{Br}_{2} \mathrm{~N}_{2} \mathrm{O}_{6} \mathrm{Pd}_{2}$ (761.062): C, 31.56; H, 3.18; N, 3.68. Found: C, 31.14; H, 3.38; N, 4.22. IR (cm $\left.{ }^{1}\right): v(\mathrm{OH}) 3423$ br s; $v(\mathrm{NH}) 3295 \mathrm{~s}, 3233 \mathrm{~s} ; v(\mathrm{CO}) 1727 \mathrm{~m} .{ }^{1} \mathrm{H}$ NMR (400.91 MHz, DMSO-d $\left.)_{6}\right): \delta 3.00$ $\left(\mathrm{dd}, 1 \mathrm{H}, \mathrm{CH}_{2},{ }^{2} J_{\mathrm{HH}}=13.6,{ }^{3} J_{\mathrm{HH}}=9.2 \mathrm{~Hz}\right), 3.12\left(\mathrm{dd}, 1 \mathrm{H}, \mathrm{CH}_{2},{ }^{2} J_{\mathrm{HH}}=13.6,{ }^{3} J_{\mathrm{HH}}=3.6 \mathrm{~Hz}\right), 3.28(\mathrm{~m}, 1 \mathrm{H}$, $\mathrm{CH}), 3.69$ (s, $3 \mathrm{H}, \mathrm{OMe}), 4.46$ (br s, $1 \mathrm{H}, \mathrm{NH}_{2}$ ), 5.40 (br s, $1 \mathrm{H}, \mathrm{NH}_{2}$ ), 6.37 (br d, $\left.1 \mathrm{H}, \mathrm{H} 3,{ }^{3} J_{\mathrm{HH}}=6.8 \mathrm{~Hz}\right)$, $6.74\left(\mathrm{br} \mathrm{d}, 1 \mathrm{H}, \mathrm{H} 2,{ }^{3} J_{\mathrm{HH}}=6.8 \mathrm{~Hz}\right), 6.91\left(\mathrm{~d}, 1 \mathrm{H}, \mathrm{H} 5,{ }^{4} J_{\mathrm{HH}}=2.4 \mathrm{~Hz}\right), 9.03($ br s, $1 \mathrm{H}, \mathrm{OH}) .{ }^{13} \mathrm{C} \mathrm{NMR}$ (100.81 MHz, DMSO- $\left.d_{6}\right): \delta 44.6\left(\mathrm{~s}, \mathrm{CH}_{2}\right), 50.7$ (s, CH), 52.8 (s, OMe), 111.7 (s, CH, C3), 119.8 (s, CH, 
C5), 126.7 (s, CH, C2), 127.3 (s, C1), 150.2 (s, C6, C-Pd), 154.1 (s, C4, C-OH), 172.3 (s, CO). The insolubility of complex $\mathbf{1 a - B r}$ in all common solvents prevented us from recrystallizating it to obtain completely satisfactory elemental analyses (it showed poor value for $\mathrm{N}$ ), and to measure its specific optical rotation.

\section{Synthesis of $(S, S)-\left[\mathrm{Pd}_{2}\left\{C, N-\mathrm{C}_{6} \mathrm{H}_{3} \mathrm{CH}_{2} \mathrm{CH}\left(\mathrm{CO}_{2} \mathrm{Me}\right) \mathrm{NH}_{2}-2,(\mathrm{OH})-4\right\}_{2}(\mu-\mathrm{OAc})_{2}\right](1 \mathrm{a}-\mathrm{OAc})$. L-tyrosine}

methyl ester (500 mg, $2.56 \mathrm{mmol})$ was added to a suspension of $\mathrm{Pd}(\mathrm{OAc})_{2}(575 \mathrm{mg}, 2.56 \mathrm{mmol})$ in $\mathrm{CH}_{2} \mathrm{Cl}_{2}(25 \mathrm{~mL})$, and the resulting mixture was stirred at room temperature for $4 \mathrm{~h}$. The solvent was removed, and acetonitrile $(35 \mathrm{~mL})$ was added. The resulting solution was heated at $70{ }^{\circ} \mathrm{C}$ for $2.5 \mathrm{~h}$. A dark brown solid formed. The mixture was filtered, the solution was concentrated to dryness, and $\mathrm{CH}_{2} \mathrm{Cl}_{2}(20 \mathrm{~mL})$ was added. The suspension was filtered, and the solid was washed with $\mathrm{Et}_{2} \mathrm{O}(2 \times 5$ $\mathrm{mL}$ ) and air-dried to give complex 1a-OAc as a dark yellow solid. Yield: $585.2 \mathrm{mg}, 0.81 \mathrm{mmol}, 63 \%$. Mp: $201{ }^{\circ} \mathrm{C}$. Anal. Calcd for $\mathrm{C}_{24} \mathrm{H}_{30} \mathrm{~N}_{2} \mathrm{O}_{10} \mathrm{Pd}_{2}$ (719.342): C, 40.07; H, 4.20; N, 3.89. Found: C, 40.30; $\mathrm{H}$, 3.76; N, 3.92. IR $\left(\mathrm{cm}^{-1}\right): v(\mathrm{NH}) 3240$ br vs; $v(\mathrm{CO}) 1735 \mathrm{~s} ; v(\mathrm{CO})_{\mathrm{OAc}} 1567$ br vs. ${ }^{1} \mathrm{H}$ NMR $(400.91 \mathrm{MHz}$, DMSO- $\left.d_{6}\right): \delta 1.80(\mathrm{~s}, 3 \mathrm{H}, \mathrm{Me}, \mathrm{OAc}), 3.01\left(\mathrm{dd}, 1 \mathrm{H}, \mathrm{CH}_{2},{ }^{2} J_{\mathrm{HH}}=13.6,{ }^{3} J_{\mathrm{HH}}=7.6 \mathrm{~Hz}\right), 3.14(\mathrm{dd}, 1 \mathrm{H}$, $\mathrm{CH}_{2},{ }^{2} J_{\mathrm{HH}}=13.6,{ }^{3} J_{\mathrm{HH}}=3.6 \mathrm{~Hz}$ ), 3.24-3.30 (br m, partially obscured by the signal of $\mathrm{H}_{2} \mathrm{O}$ of the solvent, $1 \mathrm{H}, \mathrm{CH}), 3.63(\mathrm{~s}, 3 \mathrm{H}, \mathrm{OMe}), 5.36$ (br s, $1 \mathrm{H}, \mathrm{NH}_{2}$ ), 6.01 (br s, $\left.1 \mathrm{H}, \mathrm{NH}_{2}\right), 6.32\left(\mathrm{dd}, 1 \mathrm{H}, \mathrm{H} 3,{ }^{3} J_{\mathrm{HH}}=7.8\right.$, $\left.{ }^{4} J_{\mathrm{HH}}=2.1 \mathrm{~Hz}\right), 6.68\left(\mathrm{~d}, 1 \mathrm{H}, \mathrm{H} 2,{ }^{3} J_{\mathrm{HH}}=8.1 \mathrm{~Hz}\right), 6.87\left(\mathrm{~d}, 1 \mathrm{H}, \mathrm{H} 5,{ }^{4} J_{\mathrm{HH}}=2.1 \mathrm{~Hz}\right), 8.93(\mathrm{br} \mathrm{s}, 1 \mathrm{H}, \mathrm{OH})$. ${ }^{13} \mathrm{C}$ NMR (100.81 MHz, DMSO-d $\left.d_{6}\right): \delta 44.6\left(\mathrm{~s}, \mathrm{CH}_{2}\right), 50.3(\mathrm{~s}, \mathrm{CH}), 52.5(\mathrm{~s}, \mathrm{OMe}), 111.3(\mathrm{~s}, \mathrm{CH}, \mathrm{C} 3)$, 120.7 (s, CH, C5), 126.6 (s, CH, C2), 127.6 (s, C1), 144.8 (s, C6, C-Pd), 153.5 (s, C4, C-OH), 172.2 (s, CO). The ${ }^{13} \mathrm{C}$ signals corresponding to the acetate group were not observed. $[\alpha]_{\mathrm{D}}{ }^{20}=+3.44(\mathrm{c}=0.20$, $\mathrm{MeOH})$.

\section{Synthesis of $\quad\left[\mathrm{Pd}_{2}\left\{C, N-\mathrm{C}_{6} \mathrm{H}_{2} \mathrm{CH}_{2} \mathrm{CH}_{2} \mathrm{NH}_{2}-6,(\mathrm{OMe})_{2}-3,4\right\}_{2}(\mu-\mathrm{Br})_{2}\right] \cdot \mathrm{H}_{2} \mathrm{O} \quad\left(\mathbf{1 b}-\mathrm{Br} \cdot \mathrm{H}_{2} \mathrm{O}\right)$. The} ammonium triflate $\mathbf{B}(1 \mathrm{~g}, 3.02 \mathrm{mmol})$ was added to a suspension of $\mathrm{Pd}(\mathrm{OAc})_{2}(678 \mathrm{mg}, 3.02 \mathrm{mmol})$ in acetonitrile $(50 \mathrm{~mL})$, and the resulting solution was heated at $60{ }^{\circ} \mathrm{C}$ for $2 \mathrm{~h}$ and then at $78{ }^{\circ} \mathrm{C}$ for $6 \mathrm{~h}$. The mixture was filtered through a plug of Celite, the solvent was removed from the filtrate, acetone $(40 \mathrm{ml})$ 
and $\mathrm{NaBr}(1 \mathrm{~g}, 9.72 \mathrm{mmol})$ were added, and the suspension was stirred for $12 \mathrm{~h}$. The solvent was removed, and $\mathrm{CH}_{2} \mathrm{Cl}_{2}(40 \mathrm{~mL})$ was added. The suspension was filtered, and the solid was washed with $\mathrm{H}_{2} \mathrm{O}(2 \times 5 \mathrm{~mL})$ and $\mathrm{Et}_{2} \mathrm{O}(2 \times 5 \mathrm{~mL})$, and air-dried to give complex $\mathbf{1 b}-\mathbf{B r} \cdot \mathrm{H}_{2} \mathrm{O}$ as a yellow solid. Yield: $1062 \mathrm{mg}, 1.41 \mathrm{mmol}, 94 \%$. Dec pt: $163{ }^{\circ} \mathrm{C}$. Anal. Calcd for $\mathrm{C}_{20} \mathrm{H}_{28} \mathrm{Br}_{2} \mathrm{~N}_{2} \mathrm{O}_{4} \mathrm{Pd}_{2} \cdot \mathrm{H}_{2} \mathrm{O}$ (751.117): C, 31.98 ; H, 4.02; N, 3.73. Found: C, 31.90; H, 3.70; N, 3.79. IR $\left(\mathrm{cm}^{-1}\right): v(\mathrm{NH}) 3340 \mathrm{w}, 3218 \mathrm{~m}, 3265 \mathrm{~s} .{ }^{1} \mathrm{H}$ NMR (400.91 MHz, DMSO-d $)_{6}$ : $\delta 2.31$ (br s, $2 \mathrm{H}, \mathrm{CH}_{2} \mathrm{~N}$ ), 2.76 (br s, $\left.2 \mathrm{H}, \mathrm{CH}_{2} \mathrm{Ar}\right), 3.31\left(\mathrm{~s}, \mathrm{H}_{2} \mathrm{O}\right), 3.67$ (s, $3 \mathrm{H}$, OMe), 3.68 (s, 3 H, OMe), 4.72 (br s, 2 H, NH N $_{2}, 6.63$ (s, $\left.1 \mathrm{H}, \mathrm{H} 2\right), 7.08$ (s, $\left.1 \mathrm{H}, \mathrm{H} 5\right) .{ }^{13} \mathrm{C}$ NMR $(100.81$ MHz, DMSO- $\left.d_{6}\right): \delta 37.6\left(\mathrm{~s}, \mathrm{CH}_{2} \mathrm{~N}\right), 41.7\left(\mathrm{~s}, \mathrm{CH}_{2} \mathrm{Ar}\right), 55.7(\mathrm{~s}, \mathrm{OMe}), 55.8(\mathrm{~s}, \mathrm{OMe}), 110.9$ (s, CH, C2), 117.3 (br s, CH, C5), 131.2 (s, C1), 138.3 (br s, C6), 144.8 (s, C4), 146.5 (s, C3).

\section{Synthesis of $\left[\mathrm{Pd}_{2}\left\{C, N-\mathrm{C}_{6} \mathrm{H}_{2} \mathrm{CH}_{2} \mathrm{CH}_{2} \mathrm{NH}_{2}-6,(\mathrm{OMe})_{2}-3,4\right\}_{2}(\mu-\mathrm{OAc})_{2}\right] \cdot \mathrm{H}_{2} \mathrm{O} \quad\left(\mathbf{1 b}-\mathrm{OAc} \cdot \mathrm{H}_{2} \mathrm{O}\right) . A \mathrm{AgClO}_{4}$}

(68 $\mathrm{mg}, 0.33 \mathrm{mmol}$ ) was added to a suspension of complex $\mathbf{1 b}-\mathbf{B r} \cdot \mathrm{H}_{2} \mathrm{O}(120 \mathrm{mg}, 0.16 \mathrm{mmol})$ in acetone $(30 \mathrm{~mL})$, and the resulting suspensión was stirred for $1 \mathrm{~h}$. The mixture was filtered through a plug of Celite to remove the $\mathrm{AgBr}$ formed. NaOAc (1 $\mathrm{g}, 12.20 \mathrm{mmol}$ ) was added, and the suspension was stirred for $12 \mathrm{~h}$. The solvent was removed, and $\mathrm{CH}_{2} \mathrm{Cl}_{2}(30 \mathrm{~mL})$ was added. The mixture was filtered through a plug of Celite, the filtrate was concentrated to ca. $2 \mathrm{~mL}$, and $n$-pentane $(30 \mathrm{~mL})$ was added. The suspension was filtered, and the solid was washed with $n$-pentane $(2 \times 5 \mathrm{~mL})$ and air-dried to give complex 1b-OAc $\cdot \mathrm{H}_{2} \mathrm{O}$ as a yellow solid. Yield: $83 \mathrm{mg}, 0.12 \mathrm{mmol}, 73 \%$. Mp: $139{ }^{\circ} \mathrm{C}$. Anal. Calcd for $\mathrm{C}_{24} \mathrm{H}_{34} \mathrm{~N}_{2} \mathrm{O}_{8} \mathrm{Pd}_{2} \cdot \mathrm{H}_{2} \mathrm{O}$ (709.398): C, 40.63; H, 5.11; N, 3.95. Found: C, 40.54; H, 5.36; N, 3.89. IR (cm $\left.{ }^{-1}\right)$ : $v(\mathrm{OH}) 3413$ br, $v(\mathrm{NH}) 3272 \mathrm{~m}, 3215 \mathrm{~m} ; v(\mathrm{CO})_{\mathrm{OAc}} 1563$ br s. ${ }^{1} \mathrm{H}$ NMR $(400.91 \mathrm{MHz}): \delta 1.80(\mathrm{~s}, 2 \mathrm{H}$, $\mathrm{H}_{2} \mathrm{O}$ ), 2.02 (s, $\left.3 \mathrm{H}, \mathrm{Me}, \mathrm{AcO}\right), 2.21-2.32$ (br s, $1 \mathrm{H}, \mathrm{CH}_{2} \mathrm{Ar}$ ), 2.33-2.38 (br s, $1 \mathrm{H}, \mathrm{CH}_{2} \mathrm{Ar}$ ), 2.48 (m, $1 \mathrm{H}$, $\left.\mathrm{CH}_{2} \mathrm{~N}\right), 2.69\left(\mathrm{br} \mathrm{dd}, 1 \mathrm{H}, \mathrm{CH}_{2} \mathrm{~N},{ }^{2} J_{\mathrm{HH}}=14.8 \mathrm{~Hz},{ }^{3} J_{\mathrm{HH}}=6.4 \mathrm{~Hz}\right), 2.88\left(\mathrm{br} \mathrm{s}, 1 \mathrm{H}, \mathrm{NH}_{2}\right), 3.40($ br s, $1 \mathrm{H}$, $\left.\mathrm{NH}_{2}\right), 3.80(\mathrm{~s}, 3 \mathrm{H}, \mathrm{OMe}), 3.81(\mathrm{~s}, 3 \mathrm{H}, \mathrm{OMe}), 6.43$ (s, $\left.1 \mathrm{H}, \mathrm{H} 2\right), 6.69$ (s, $\left.1 \mathrm{H}, \mathrm{H} 5\right) .{ }^{13} \mathrm{C}$ NMR $(75.45$ MHz): $\delta 24.3$ (s, Me), $39.2\left(\mathrm{~s}, \mathrm{CH}_{2} \mathrm{Ar}\right), 40.6\left(\mathrm{~s}, \mathrm{CH}_{2} \mathrm{~N}\right), 55.8$ (s, OMe), 55.9 (s, OMe), 110.9 (s, CH, C2), 115.4 (s, CH, C5), 124.6 (s, C, C6), 129.6 (s, C1), 144.8 (s, C4), 146.1 (s, C3), 181.2 (s, CO). 
Synthesis of $\left[\mathrm{Pd}\left\{\mathrm{C}, \boldsymbol{N}-\mathrm{C}_{6} \mathrm{H}_{2} \mathrm{CH}_{2} \mathrm{CH}_{2} \mathrm{NH}_{2}-\mathbf{6},(\mathrm{OMe})_{2}-\mathbf{3 , 4}\right\}\left(\mathrm{O}, \boldsymbol{O}^{\prime}\right.\right.$-acac)] (2b). Tl(acac) (125 mg, 0.41

mmol) was added to a suspension of complex $\mathbf{1 b}-\mathbf{B r} \cdot \mathrm{H}_{2} \mathrm{O}(150 \mathrm{mg}, 0.20 \mathrm{mmol})$ in acetone $(25 \mathrm{~mL})$, and the mixture was stirred for $1 \mathrm{~h}$. The solvent was removed under vacuum, and $\mathrm{CH}_{2} \mathrm{Cl}_{2}(30 \mathrm{~mL})$ was added. The resulting suspension was filtered through a plug of $\mathrm{MgSO}_{4}$, the filtrate was concentrated to ca. $2 \mathrm{~mL}$, and $\mathrm{Et}_{2} \mathrm{O}(30 \mathrm{~mL})$ was added. The suspension was filtered, and the solid was washed with $\mathrm{Et}_{2} \mathrm{O}(2 \times 5 \mathrm{~mL})$ and air-dried to give complex $\mathbf{2 b}$ as a yellow solid. Yield: $120.4 \mathrm{mg}, 0.31 \mathrm{mmol}, 78 \%$. Mp: $195^{\circ} \mathrm{C}$. Anal. Calcd for $\mathrm{C}_{15} \mathrm{H}_{21} \mathrm{NO}_{4} \mathrm{Pd}$ (385.736): C, 46.71; H, 5.49; N, 3.63. Found: C, 46.36; H, 5.52; N, 3.83. IR (cm $\left.{ }^{-1}\right): v(\mathrm{NH}) 3273 \mathrm{~m}, 3220 \mathrm{~m}, 3148 \mathrm{~m} ; v(\mathrm{CO}) 1588 \mathrm{~s}, 1508 \mathrm{~s} .{ }^{1} \mathrm{H}$ NMR $(300.1 \mathrm{MHz})$ : $\delta 1.91(\mathrm{~s}, 3 \mathrm{H}, \mathrm{Me}), 2.02\left(\mathrm{~s}, 3 \mathrm{H}, \mathrm{Me}\right.$ ), 2.68 (quint, $2 \mathrm{H}, \mathrm{CH}_{2} \mathrm{~N},{ }^{3} J_{\mathrm{HH}}=5.6 \mathrm{~Hz}$ ), 2.88 (“t”, $2 \mathrm{H}, \mathrm{CH}_{2} \mathrm{Ar}$, $\left.{ }^{3} J_{\mathrm{HH}}=5.7 \mathrm{~Hz}\right), 3.24\left(\mathrm{br} \mathrm{s}, 2 \mathrm{H}, \mathrm{NH}_{2}\right), 3.82(\mathrm{~s}, 3 \mathrm{H}, \mathrm{OMe}), 3.90(\mathrm{~s}, 3 \mathrm{H}, \mathrm{OMe}), 5.32(\mathrm{~s}, 1 \mathrm{H}, \mathrm{CH}), 6.49(\mathrm{~s}$, $1 \mathrm{H}, \mathrm{H} 2), 7.14$ (s, $1 \mathrm{H}, \mathrm{H} 5) .{ }^{13} \mathrm{C}$ NMR (75.45 MHz): $\delta 27.7$ (s, MeCO), 27.8 (s, MeCO), 39.8 (s, $\left.\mathrm{CH}_{2} \mathrm{Ar}\right)$, 40.9 (s, $\left.\mathrm{CH}_{2} \mathrm{~N}\right), 55.7$ (s, OMe), 56.1 (s, OMe), 100.1 (s, CH), 110.6 (s, CH, C2), 115.4 (s, CH, C5), 128.2 (s, C6), 130.1 (s, C1), 145.0 (s, C4, C-OMe), 146.2 (s, C3, C-OMe), 186.9 (s, CO), 187.2 (s, CO).

\section{Synthesis of $(\mathrm{S})-\left[\mathrm{Pd}\left\{\mathrm{C}, \mathrm{N}-\mathrm{C}_{6} \mathrm{H}_{3} \mathrm{CH}_{2} \mathrm{CH}\left(\mathrm{CO}_{2} \mathrm{Me}\right) \mathrm{NH}_{2}-2,(\mathrm{OH})-4\right\} \mathrm{Br}\left(\mathrm{PPh}_{3}\right)\right](3 \mathrm{a}-\mathrm{Br}) . \mathrm{PPh}_{3}(55.1 \mathrm{mg}$,} $0.21 \mathrm{mmol})$ was added to a suspension of complex $1 \mathbf{a}-\mathbf{B r}(80 \mathrm{mg}, 0.11 \mathrm{mmol})$ in $\mathrm{CH}_{2} \mathrm{Cl}_{2}(20 \mathrm{~mL})$, and the resulting solution was stirred for $30 \mathrm{~min}$. The mixture was filtered through a plug of $\mathrm{MgSO}_{4}$, the filtrate was concentrated to ca. $2 \mathrm{~mL}$, and $n$-pentane $(15 \mathrm{~mL})$ was added. The suspension was filtered, and the solid was washed with $n$-pentane $(2 \times 5 \mathrm{~mL})$ and air-dried to give complex $\mathbf{3 a - B r}$ as a yellow solid. Yield: $73.7 \mathrm{mg}, 0.12 \mathrm{mmol}, 55 \%$. Mp: $135{ }^{\circ} \mathrm{C}$. Anal. Calcd for $\mathrm{C}_{28} \mathrm{H}_{27} \mathrm{BrNO}_{3} \mathrm{PPd}$ (642.817): C, 52.32; H, 4.23; N, 2.18. Found: C, 52.03; H, 4.23; N, 2.23. IR $\left(\mathrm{cm}^{-1}\right): v(\mathrm{NH}) 3320 \mathrm{~m} 3252 \mathrm{w} ; v(\mathrm{CO})$ $1737 \mathrm{~m} .{ }^{1} \mathrm{H}$ NMR (400.91 MHz): $\delta 3.23\left(\mathrm{dd}, 1 \mathrm{H}, \mathrm{CH}_{2},{ }^{2} J_{\mathrm{HH}}=13.6,{ }^{3} J_{\mathrm{HH}}=3.2 \mathrm{~Hz}\right), 3.66(\mathrm{dd}$, partially obscured by the signal of OMe, $\left.1 \mathrm{H}, \mathrm{CH}_{2},{ }^{2} J_{\mathrm{HH}}=13.2,{ }^{3} J_{\mathrm{HH}}=5.6 \mathrm{~Hz}\right), 3.70(\mathrm{~s}, 3 \mathrm{H}, \mathrm{OMe}), 3.88(\mathrm{br} \mathrm{s}, 1$ $\mathrm{H}, \mathrm{CH}), 3.93$ (br s, $1 \mathrm{H}, \mathrm{NH}_{2}$ ), 4.05 (br s, $1 \mathrm{H}, \mathrm{NH}_{2}$ ), $5.84\left(\mathrm{dd}, 1 \mathrm{H}, \mathrm{H} 5,{ }^{4} J_{\mathrm{HP}}=5.2,{ }^{4} J_{\mathrm{HH}}=2.4 \mathrm{~Hz}\right), 6.23$ $\left(\mathrm{dd}, 1 \mathrm{H}, \mathrm{H} 3,{ }^{3} J_{\mathrm{HH}}=8.0,{ }^{4} J_{\mathrm{HH}}=2.4 \mathrm{~Hz}\right), 6.62\left(\mathrm{~d}, 1 \mathrm{H}, \mathrm{H} 2,{ }^{3} J_{\mathrm{HH}}=8.0 \mathrm{~Hz}\right), 7.29-7.34\left(\mathrm{~m}, 6 \mathrm{H}, m-\mathrm{H}, \mathrm{PPh}_{3}\right)$, 7.38-7.42 (m, $4 \mathrm{H}, \mathrm{OH}+p-\mathrm{H}$ of $\left.\mathrm{PPh}_{3}\right), 7.53-7.58\left(\mathrm{~m}, 6 \mathrm{H}, o-\mathrm{H}, \mathrm{PPh}_{3}\right) .{ }^{13} \mathrm{C} \mathrm{NMR}(75.45 \mathrm{MHz}): \delta 45.5$ 
$\left(\mathrm{s}, \mathrm{CH}_{2}\right), 50.4(\mathrm{~s}, \mathrm{CH}), 52.9(\mathrm{~s}, \mathrm{OMe}), 110.8(\mathrm{~s}, \mathrm{CH}, \mathrm{C} 3), 123.3\left(\mathrm{~d}, \mathrm{CH}, \mathrm{C} 5,{ }^{3} J_{\mathrm{CP}}=9.9 \mathrm{~Hz}\right), 126.8(\mathrm{~s}, \mathrm{CH}$, C2), $127.6(\mathrm{~s}, \mathrm{C} 1), 128.0\left(\mathrm{~d}, m-\mathrm{CH}, \mathrm{PPh}_{3},{ }^{3} J_{\mathrm{CP}}=10.8 \mathrm{~Hz}\right), 130.7\left(\mathrm{~s}, p-\mathrm{CH}, \mathrm{PPh}_{3}\right), 131.0\left(\mathrm{~d}, i-\mathrm{C}, \mathrm{PPh}_{3}\right.$, $\left.{ }^{1} J_{\mathrm{CP}}=51.0 \mathrm{~Hz}\right), 134.8\left(\mathrm{~d}, o-\mathrm{CH}, \mathrm{PPh}_{3},{ }^{2} J_{\mathrm{CP}}=11.5 \mathrm{~Hz}\right), 152.6(\mathrm{~s}, \mathrm{C} 4, \mathrm{C}-\mathrm{OH}), 155.1(\mathrm{~s}, \mathrm{C} 6, \mathrm{C}-\mathrm{Pd}), 172.6$ (s, CO). ${ }^{31} \mathrm{P}$ NMR $(162.29 \mathrm{MHz}): \delta 35.9\left(\mathrm{~s}, \mathrm{PPh}_{3}\right) \cdot[\alpha]_{\mathrm{D}}{ }^{20}=+49.54\left(\mathrm{c}=0.20, \mathrm{CH}_{2} \mathrm{Cl}_{2}\right)$.

\section{Synthesis of $(S)-\left[\mathrm{Pd}\left\{C, N-\mathrm{C}_{6} \mathrm{H}_{3} \mathrm{CH}_{2} \mathrm{CH}\left(\mathrm{CO}_{2} \mathrm{Me}\right) \mathrm{NH}_{2}-2,(\mathrm{OH})-4\right\}(\mathrm{OAc}) \mathrm{PPh}_{3}\right] \cdot \mathrm{H}_{2} \mathrm{O} \quad\left(3 \mathrm{a}-\mathrm{OAc} \cdot \mathrm{H}_{2} \mathrm{O}\right)$.}

$\mathrm{PPh}_{3}(73 \mathrm{mg}, 0.28 \mathrm{mmol})$ was added to a suspension of complex 1a-OAc $(150 \mathrm{mg}, 0.21 \mathrm{mmol})$ in $\mathrm{CH}_{2} \mathrm{Cl}_{2}(20 \mathrm{~mL})$, and the resulting solution was stirred for $2 \mathrm{~h}$. The mixture was filtered through a plug of $\mathrm{MgSO}_{4}$, the filtrate was concentrated to ca. $2 \mathrm{~mL}$, and $\mathrm{Et}_{2} \mathrm{O}(15 \mathrm{~mL})$ was added. The suspension was filtered, and the solid was washed with $\mathrm{Et}_{2} \mathrm{O}(2 \times 5 \mathrm{~mL})$ and air-dried to give complex $\mathbf{3 a - O A c} \cdot \mathrm{H}_{2} \mathrm{O}$ as a yellow solid. Yield: $153 \mathrm{mg}, 0.24 \mathrm{mmol}, 57 \%$. Mp: $181{ }^{\circ} \mathrm{C}$. Anal. Calcd for $\mathrm{C}_{30} \mathrm{H}_{30} \mathrm{NO}_{5} \mathrm{PPd} \cdot \mathrm{H}_{2} \mathrm{O}$ (639.972): C, 56.30; H, 5.04; N, 2.19. Found: C, 56.16; H, 4.86; N, 2.28. IR (cm $\left.{ }^{-1}\right): v(\mathrm{NH}) 3319 \mathrm{~m}$, $3262 \mathrm{~m} ; v(\mathrm{CO}) 1736 \mathrm{~s} ; v(\mathrm{CO})_{\mathrm{OAc}} 1572 \mathrm{br} \mathrm{s} .{ }^{1} \mathrm{H}$ NMR $(300.1 \mathrm{MHz}): \delta 1.45$ (s, $\left.3 \mathrm{H}, \mathrm{Me}, \mathrm{OAc}\right), 1.86$ (br s, $\left.2 \mathrm{H}, \mathrm{H}_{2} \mathrm{O}\right), 3.25\left(\mathrm{dd}, 1 \mathrm{H}, \mathrm{CH}_{2},{ }^{2} J_{\mathrm{HH}}=13.5,{ }^{3} J_{\mathrm{HH}}=3.6 \mathrm{~Hz}\right), 3.62(\mathrm{dd}$, partially obscured by the signal of OMe, $\left.1 \mathrm{H}, \mathrm{CH}_{2},{ }^{3} J_{\mathrm{HH}}=4.8 \mathrm{~Hz}\right), 3.65(\mathrm{~s}, 3 \mathrm{H}, \mathrm{OMe}), 3.72(\mathrm{br} \mathrm{s}, 1 \mathrm{H}, \mathrm{CH}), 3.86$ (br s, $\left.1 \mathrm{H}, \mathrm{NH}_{2}\right), 5.21$ (br $\left.\mathrm{s}, 1 \mathrm{H}, \mathrm{NH}_{2}\right), 5.72\left(\mathrm{dd}, 1 \mathrm{H}, \mathrm{H} 5,{ }^{4} J_{\mathrm{HP}}=5.1,{ }^{4} J_{\mathrm{HH}}=2.1 \mathrm{~Hz}\right), 6.37\left(\mathrm{dd}, 1 \mathrm{H}, \mathrm{H} 3,{ }^{3} J_{\mathrm{HH}}=7.8,{ }^{4} J_{\mathrm{HH}}=1.8 \mathrm{~Hz}\right)$, 6.63 (br s, $1 \mathrm{H}, \mathrm{OH}), 6.69\left(\mathrm{~d}, 1 \mathrm{H}, \mathrm{H} 2,{ }^{3} J_{\mathrm{HH}}=7.8 \mathrm{~Hz}\right), 7.24-7.31\left(\mathrm{~m}, 6 \mathrm{H}, m-\mathrm{H}, \mathrm{PPh}_{3}\right), 7.34-7.46(\mathrm{~m}, 9$ $\left.\mathrm{H}, o-\mathrm{H}+p-\mathrm{H}, \mathrm{PPh}_{3}\right) .{ }^{13} \mathrm{C} \mathrm{NMR}(75.45 \mathrm{MHz}): \delta 24.2(\mathrm{~s}, \mathrm{Me}, \mathrm{OAc}), 46.1\left(\mathrm{~s}, \mathrm{CH}_{2}\right), 50.5(\mathrm{~s}, \mathrm{CH}), 52.7(\mathrm{~s}$, OMe), $111.2(\mathrm{~s}, \mathrm{CH}, \mathrm{C} 3), 124.3\left(\mathrm{~d}, \mathrm{CH}, \mathrm{C} 5,{ }^{3} J_{\mathrm{CP}}=10.9 \mathrm{~Hz}\right), 126.7(\mathrm{~s}, \mathrm{CH}, \mathrm{C} 2), 127.9(\mathrm{~s}, \mathrm{C} 1), 128.2(\mathrm{~d}$, $\left.m-\mathrm{CH}, \mathrm{PPh}_{3},{ }^{3} J_{\mathrm{CP}}=10.6 \mathrm{~Hz}\right), 130.2\left(\mathrm{~d}, i-\mathrm{C}, \mathrm{PPh}_{3},{ }^{1} J_{\mathrm{CP}}=49.1 \mathrm{~Hz}\right), 130.3\left(\mathrm{~s}, p-\mathrm{CH}, \mathrm{PPh}_{3}\right), 134.5(\mathrm{~d}, o-\mathrm{CH}$, $\left.\mathrm{PPh}_{3},{ }^{2} J_{\mathrm{CP}}=11.8 \mathrm{~Hz}\right), 146.9(\mathrm{~s}, \mathrm{C} 6, \mathrm{C}-\mathrm{Pd}), 152.9\left(\mathrm{~d}, \mathrm{C} 5,{ }^{4} J_{\mathrm{CP}}=4.6 \mathrm{~Hz}\right), 172.9\left(\mathrm{~s}, \mathrm{CO}_{2} \mathrm{Me}\right), 179.3(\mathrm{~s}, \mathrm{CO}$ OAc). ${ }^{31} \mathrm{P}$ NMR $(121.5 \mathrm{MHz}): \delta 33.6\left(\mathrm{~s}, \mathrm{PPh}_{3}\right) .[\alpha]_{\mathrm{D}}{ }^{20}=+3.38(\mathrm{c}=0.20, \mathrm{MeOH})$. Single crystals of 3aOAc, suitable for X-ray diffraction study, were obtained by slow diffusion of $n$-pentane into a solution of 3a-OAc $\cdot \mathrm{H}_{2} \mathrm{O}$ in $\mathrm{CHCl}_{3}$.

Synthesis of $\left[\mathrm{Pd}\left\{\mathrm{C}, \mathrm{N}-\mathrm{C}_{6} \mathrm{H}_{2} \mathrm{CH}_{2} \mathrm{CH}_{2} \mathrm{NH}_{2}-6,(\mathrm{OMe})_{2}-3,4\right\} \mathrm{Br}\left(\mathrm{PPh}_{3}\right)\right](3 \mathrm{~b}-\mathrm{Br})$. Method A. $\mathrm{PPh}_{3}(107$ $\mathrm{mg}, 0.41 \mathrm{mmol})$ was added to a suspension of complex $\mathbf{1 b}-\mathbf{B r} \cdot \mathrm{H}_{2} \mathrm{O}(150 \mathrm{mg}, 0.20 \mathrm{mmol})$ in $\mathrm{CH}_{2} \mathrm{Cl}_{2}(30$ 
$\mathrm{mL}$ ), and the resulting solution was stirred for $1 \mathrm{~h}$. The mixture was filtered through a plug of Celite, the filtrate was concentrated to ca. $2 \mathrm{~mL}$, and $\mathrm{Et}_{2} \mathrm{O}(30 \mathrm{~mL})$ was added. The suspension was filtered, and the solid was washed with $\mathrm{Et}_{2} \mathrm{O}(2 \times 5 \mathrm{~mL})$ and air-dried to give a first crop of complex $\mathbf{3 b}-\mathbf{B r}(63 \mathrm{mg})$. The filtrate was concentrated to ca. $2 \mathrm{~mL}$ and $n$-pentane $(30 \mathrm{~mL})$ was added. The suspension was filtered, and the solid was washed with $n$-pentane $(2 \times 5 \mathrm{~mL})$ and air-dried to give a second crop of complex $3 \mathbf{b}$ Br as a yellow solid (73 mg). Yield: $136 \mathrm{mg}, 0.22 \mathrm{mmol}, 54 \%$. Method B. $\mathrm{PPh}_{3}(54.3 \mathrm{mg}, 0.21 \mathrm{mmol})$ was added to a suspension of complex $9 \mathbf{b}(100 \mathrm{mg}, 0.21 \mathrm{mmol})$ in $\mathrm{CH}_{2} \mathrm{Cl}_{2}(25 \mathrm{~mL})$, and the resulting solution was stirred for $3 \mathrm{~h}$. The mixture was filtered through a plug of $\mathrm{MgSO}_{4}$, the filtrate was concentrated to ca. $1 \mathrm{~mL}$, and $\mathrm{Et}_{2} \mathrm{O}(15 \mathrm{~mL})$ was added. The suspension was filtered, and the solid was washed with $\mathrm{Et}_{2} \mathrm{O}(2 \times 5 \mathrm{~mL})$ and air-dried to give complex $\mathbf{3 b - B r}$ as a pale yellow solid. Yield: 75.3 mg, $0.12 \mathrm{mmol}, 58 \%$. Mp: $147{ }^{\circ} \mathrm{C}$. Anal. Calcd for $\mathrm{C}_{28} \mathrm{H}_{29} \mathrm{BrNO}_{2} \mathrm{PPd}$ (628.833): C, 53.48; H, 4.65; N, 2.23. Found: C, 53.42; H, 4.69; N, 2.39. IR $\left(\mathrm{cm}^{-1}\right): v(\mathrm{NH}) 3259 \mathrm{~m}, 3210 \mathrm{~m} .{ }^{1} \mathrm{H}$ NMR (400.91 MHz): $\delta$ 2.77 (br s, $\left.2 \mathrm{H}, \mathrm{CH}_{2} \mathrm{~N}\right), 3.12(\mathrm{~s}, 3 \mathrm{H}, \mathrm{OMe}), 3.13$ (m, partially obscured by the signal of OMe, $2 \mathrm{H}$, $\left.\mathrm{CH}_{2} \mathrm{Ar}\right), 3.39$ (br s, $\left.2 \mathrm{H}, \mathrm{NH}_{2}\right), 3.77(\mathrm{~s}, 3 \mathrm{H}, \mathrm{OMe}), 5.99\left(\mathrm{~d}, 1 \mathrm{H}, \mathrm{H} 5,{ }^{4} J_{\mathrm{HP}}=4.8 \mathrm{~Hz}\right), 6.54(\mathrm{~s}, 1 \mathrm{H}, \mathrm{H} 2)$, 7.28-7.33 (m, $\left.6 \mathrm{H}, m-\mathrm{H}, \mathrm{PPh}_{3}\right), 7.36-7.41\left(\mathrm{~m}, 3 \mathrm{H}, p-\mathrm{H}, \mathrm{PPh}_{3}\right), 7.49-7.55\left(\mathrm{~m}, 6 \mathrm{H}, o-\mathrm{H}, \mathrm{PPh}_{3}\right) .{ }^{13} \mathrm{C}$ NMR (100.81 MHz): $\delta 37.7\left(\mathrm{~s}, \mathrm{CH}_{2} \mathrm{~N}\right), 42.5$ (s, $\mathrm{CH}_{2} \mathrm{Ar}$ ), 55.0 (s, OMe), 56.0 (s, OMe), 110.4 (s, CH, $\mathrm{C} 2), 118.7\left(\mathrm{~d}, \mathrm{CH}, \mathrm{C} 5,{ }^{3} J_{\mathrm{CP}}=11.9 \mathrm{~Hz}\right), 128.1\left(\mathrm{~d}, m-\mathrm{CH}, \mathrm{PPh}_{3},{ }^{3} J_{\mathrm{CP}}=10.6 \mathrm{~Hz}\right), 130.4\left(\mathrm{~d}, p-\mathrm{CH}, \mathrm{PPh}_{3},{ }^{4} J_{\mathrm{CP}}\right.$ $=2.2 \mathrm{~Hz}), 131.4\left(\mathrm{~d}, i-\mathrm{C}, \mathrm{PPh}_{3},{ }^{1} J_{\mathrm{CP}}=49.8 \mathrm{~Hz}\right), 134.8\left(\mathrm{~d}, o-\mathrm{CH}, \mathrm{PPh}_{3},{ }^{2} J_{\mathrm{CP}}=11.5 \mathrm{~Hz}\right), 142.2(\mathrm{~s}, \mathrm{C} 6)$, $145.5\left(\mathrm{~d}, \mathrm{C} 4,{ }^{4} J_{\mathrm{CP}}=4.8 \mathrm{~Hz}\right), 146.1(\mathrm{~s}, \mathrm{C} 3)$. The C1 resonance was not observed. ${ }^{31} \mathrm{P} \mathrm{NMR}(81.01 \mathrm{MHz})$ : $\delta 35.5\left(\mathrm{~s}, \mathrm{PPh}_{3}\right)$.

\section{Synthesis of $\left[\mathrm{Pd}\left\{\mathrm{C}, \mathrm{N}-\mathrm{C}_{6} \mathrm{H}_{2} \mathrm{CH}_{2} \mathrm{CH}_{2} \mathrm{NH}_{2}-6,(\mathrm{OMe})_{2}-3,4\right\}(\mathrm{OAc}) \mathrm{PPh}_{3}\right] \cdot 0.25 \mathrm{H}_{2} \mathrm{O} \quad\left(3 \mathrm{~b}-\mathrm{OAc} \cdot 0.25 \mathrm{H}_{2} \mathrm{O}\right)$.}

$\mathrm{PPh}_{3}(61 \mathrm{mg}, 0.23 \mathrm{mmol})$ was added to a solution of complex 1b-OAc $\cdot \mathrm{H}_{2} \mathrm{O}(80 \mathrm{mg}, 0.11 \mathrm{mmol})$ in $\mathrm{CH}_{2} \mathrm{Cl}_{2}(30 \mathrm{~mL})$, and the resulting mixture was stirred for $30 \mathrm{~min}$ and then filtered through a plug of Celite. The filtrate was concentrated to ca. $2 \mathrm{~mL}$, and $n$-pentane $(15 \mathrm{~mL})$ was added. The suspension was filtered, and the solid was washed with $n$-pentane $(2 \times 5 \mathrm{~mL})$ and air-dried to give complex $3 \mathbf{b}$ - 
OAc $\cdot 0.25 \mathrm{H}_{2} \mathrm{O}$ as a pale yellow solid. Yield: $110 \mathrm{mg}, 0.18 \mathrm{mmol}, 79 \%$. Mp: $170{ }^{\circ} \mathrm{C}$. Anal. Calcd for $\mathrm{C}_{30} \mathrm{H}_{32} \mathrm{NO}_{4} \mathrm{PPd} \cdot 1 / 4 \mathrm{H}_{2} \mathrm{O}$ (612.467): C, 58.83; H, 5.35; N, 2.29. Found: C, 58.44; H, 5.70; N, 2.67. IR (cm ${ }^{-}$ $\left.{ }^{1}\right): v(\mathrm{NH}) 3278 \mathrm{w} ; v(\mathrm{CO})_{\mathrm{OAc}} 1572 \mathrm{br} \mathrm{s.}{ }^{1} \mathrm{H} \mathrm{NMR}(300.1 \mathrm{MHz}): \delta 1.46(\mathrm{~s}, 3 \mathrm{H}, \mathrm{Me}), 1.84\left(\mathrm{~s}, 0.5 \mathrm{H}, \mathrm{H}_{2} \mathrm{O}\right)$, 2.73 (br s, $2 \mathrm{H}, \mathrm{CH}_{2} \mathrm{~N}$ ), 3.02 (s, $3 \mathrm{H}, \mathrm{OMe}$ ), 3.14 (“ct”, $2 \mathrm{H}, \mathrm{CH}_{2} \mathrm{Ar},{ }^{3} \mathrm{~J}_{\mathrm{HH}}=5.40 \mathrm{~Hz}$ ), $3.78(\mathrm{~s}, 3 \mathrm{H}, \mathrm{OMe})$, $4.12\left(\right.$ br s, $\left.2 \mathrm{H}, \mathrm{NH}_{2}\right), 6.01\left(\mathrm{~d}, 1 \mathrm{H}, \mathrm{H} 5,{ }^{4} J_{\mathrm{HP}}=4.5 \mathrm{~Hz}\right), 6.60(\mathrm{~s}, 1 \mathrm{H}, \mathrm{H} 2), 7.30-7.36\left(\mathrm{~m}, 6 \mathrm{H}, m-\mathrm{H}, \mathrm{PPh}_{3}\right)$, 7.39-7.51 (m, $\left.9 \mathrm{H}, p-\mathrm{H}+o-\mathrm{H}, \mathrm{PPh}_{3}\right) .{ }^{13} \mathrm{C} \mathrm{NMR}(75.45 \mathrm{MHz}): \delta 24.1(\mathrm{~s}, \mathrm{Me}), 37.5\left(\mathrm{~s}, \mathrm{CH}_{2} \mathrm{~N}\right), 43.2(\mathrm{~s}$, $\left.\mathrm{CH}_{2} \mathrm{Ar}\right), 54.8(\mathrm{~s}, \mathrm{OMe}), 55.9(\mathrm{~s}, \mathrm{OMe}), 110.7(\mathrm{~s}, \mathrm{CH}, \mathrm{C} 2), 118.9\left(\mathrm{~d}, \mathrm{CH}, \mathrm{C} 5,{ }^{3} J_{\mathrm{CP}}=11.7 \mathrm{~Hz}\right), 128.3(\mathrm{~d}$, $\left.m-\mathrm{CH}, \mathrm{PPh}_{3},{ }^{3} J_{\mathrm{CP}}=10.6 \mathrm{~Hz}\right), 130.4\left(\mathrm{~s}, p-\mathrm{CH}, \mathrm{PPh}_{3}\right), 130.5\left(\mathrm{~d}, i-\mathrm{C}, \mathrm{PPh}_{3},{ }^{1} J_{\mathrm{CP}}=48.4 \mathrm{~Hz}\right), 131.7(\mathrm{~s}, \mathrm{C} 1)$, $133.4(\mathrm{~s}, \mathrm{C} 6), 134.6\left(\mathrm{~d}, o-\mathrm{CH}, \mathrm{PPh}_{3},{ }^{2} J_{\mathrm{CP}}=12.2 \mathrm{~Hz}\right), 144.9(\mathrm{~s}, \mathrm{C} 4), 146.0(\mathrm{~s}, \mathrm{C} 3)$. The CO resonance was not observed. ${ }^{31} \mathrm{P}$ NMR (121.5 MHz): $\delta 34.2\left(\mathrm{~s}, \mathrm{PPh}_{3}\right)$.

Synthesis of $\left[\mathrm{Pd}\left\{C, N-\mathrm{C}_{6} \mathrm{H}_{2} \mathrm{CH}_{2} \mathrm{CH}_{2} \mathrm{NH}_{2}-6,(\mathrm{OMe})_{2}-3,4\right\} \mathrm{Br}\left\{\mathrm{P}(p-\mathrm{To})_{3}\right\}\right](3 \mathrm{~b}$-Br $) . \mathrm{P}(p-\mathrm{To})_{3}(83 \mathrm{mg}$, $0.27 \mathrm{mmol})$ was added to a suspension of complex $\mathbf{1 b}-\mathbf{B r} \cdot \mathrm{H}_{2} \mathrm{O}(100 \mathrm{mg}, 0.13 \mathrm{mmol})$ in $\mathrm{CH}_{2} \mathrm{Cl}_{2}(30 \mathrm{~mL})$, and the resulting solution was stirred for $1 \mathrm{~h}$. The mixture was filtered through a plug of Celite, the filtrate was concentrated to ca. $2 \mathrm{~mL}$, and n-pentane (30 mL) was added. The suspension was filtered, and the solid was washed with $n$-pentane $(2 \times 5 \mathrm{~mL})$ and air-dried to give complex $\mathbf{3 b}$ '-Br as an offwhite solid. Yield: $132 \mathrm{mg}, 0.197 \mathrm{mmol}, 74 \%$. Mp: $147{ }^{\circ} \mathrm{C}$. Anal. Calcd for $\mathrm{C}_{31} \mathrm{H}_{35} \mathrm{BrNO}_{2} \mathrm{PPd}$ (670.924): C, 55.50; H, 5.26; N, 2.09. Found: C, 55.35; H, 5.32; N, 2.10. IR $\left(\mathrm{cm}^{-1}\right): v(\mathrm{NH}) 3550 \mathrm{~m}$, 3470 m, $3411 \mathrm{~m}, 3254$ w. ${ }^{1} \mathrm{H}$ NMR (300.1 MHz): $\delta 2.33$ (s, $\left.9 \mathrm{H}, \mathrm{Me}\right), 2.76$ (br s, $\left.2 \mathrm{H}, \mathrm{CH}_{2} \mathrm{~N}\right), 3.12$ (s, 3 $\mathrm{H}, \mathrm{OMe}$ ), 3.14 (m, partially obscured by the signal of $\mathrm{OMe}, 2 \mathrm{H}, \mathrm{CH}_{2} \mathrm{Ar}$ ), 3.36 (br s, $2 \mathrm{H}, \mathrm{NH}_{2}$ ), 3.77 (s, $3 \mathrm{H}, \mathrm{OMe}), 5.98\left(\mathrm{~d}, 1 \mathrm{H}, \mathrm{H} 5,{ }^{4} J_{\mathrm{HP}}=4.8 \mathrm{~Hz}\right), 6.54(\mathrm{~s}, 1 \mathrm{H}, \mathrm{H} 2), 7.10\left(\mathrm{br} \mathrm{d}, 6 \mathrm{H}, m-\mathrm{H}, \mathrm{P}(p-\mathrm{To}){ }_{3},{ }^{3} J_{\mathrm{HH}}=6.6\right.$ $\mathrm{Hz}), 7.38\left(\mathrm{dd}, 6 \mathrm{H}, o-\mathrm{H}, \mathrm{P}(p-\mathrm{To}){ }_{3},{ }^{3} J_{\mathrm{HP}}=11.4,{ }^{3} J_{\mathrm{HH}}=8.1 \mathrm{~Hz}\right) .{ }^{13} \mathrm{C} \mathrm{NMR}(75.45 \mathrm{MHz}): \delta 21.4(\mathrm{~s}, \mathrm{Me})$, $37.6\left(\mathrm{~d}, \mathrm{CH}_{2} \mathrm{~N},{ }^{3} J_{\mathrm{CP}}=2.3 \mathrm{~Hz}\right), 42.5\left(\mathrm{~s}, \mathrm{CH}_{2} \mathrm{Ar}\right), 54.9(\mathrm{~s}, \mathrm{OMe}), 56.0(\mathrm{~s}, \mathrm{OMe}), 110.3(\mathrm{~s}, \mathrm{CH}, \mathrm{C} 2), 118.8$ $\left(\mathrm{d}, \mathrm{CH}, \mathrm{C} 5,{ }^{3} J_{\mathrm{CP}}=11.8 \mathrm{~Hz}\right), 128.0$ (d, one-half of the doublet was obscured by the $m$-CH signal, $i$-C), $128.8\left(\mathrm{~d}, m-\mathrm{CH}, \mathrm{P}(p-\mathrm{To})_{3},{ }^{3} J_{\mathrm{CP}}=11.0 \mathrm{~Hz}\right), 130.5(\mathrm{~s}, \mathrm{C} 1), 134.7\left(\mathrm{~d}, o-\mathrm{CH}, \mathrm{P}(p-\mathrm{To})_{3},{ }^{2} J_{\mathrm{CP}}=11.8 \mathrm{~Hz}\right)$, 
$140.4\left(\mathrm{~d}, C-\mathrm{Me}, \mathrm{P}(p-\mathrm{To})_{3},{ }^{4} J_{\mathrm{CP}}=2.4 \mathrm{~Hz}\right), 142.1\left(\mathrm{br}\right.$ s, C6), $145.4\left(\mathrm{~d}, \mathrm{C} 4, C-\mathrm{OMe},{ }^{4} J_{\mathrm{CP}}=4.9 \mathrm{~Hz}\right), 146.0$

(s, C3, C-OMe). ${ }^{31} \mathrm{P}$ NMR $(121.50 \mathrm{MHz}): \delta 33.6\left(\mathrm{~s}, \mathrm{P}(p-\mathrm{To})_{3}\right)$.

Synthesis of $(S)-\left[\mathrm{Pd}\left\{C, N-\mathrm{C}_{6} \mathrm{H}_{3} \mathrm{CH}_{2} \mathrm{CH}\left(\mathrm{CO}_{2} \mathrm{Me}\right) \mathrm{NH}_{2}-2,(\mathrm{OH})-4\right\} \mathrm{Br}(\mathrm{CNXy})\right]$ (4a). XyNC (34.5 mg, $0.26 \mathrm{mmol})$ was added to a suspension of complex $\mathbf{1 a}-\mathbf{B r}(100 \mathrm{mg}, 0.13 \mathrm{mmol})$ in $\mathrm{CH}_{2} \mathrm{Cl}_{2}(25 \mathrm{ml})$, and the resulting solution was was stirred for $2 \mathrm{~h}$. The mixture was filtered through a plug of $\mathrm{MgSO}_{4}$, the filtrate was concentrated to ca. $2 \mathrm{~mL}$, and $\mathrm{Et}_{2} \mathrm{O}(15 \mathrm{ml})$ was added. The suspension was filtered, and the solid was washed with $\mathrm{Et}_{2} \mathrm{O}(2 \times 5 \mathrm{~mL})$, and air-dried to give a first crop of complex $4 \mathbf{a}$ as a yellow solid (30 mg). The filtrate was concentrated to ca. $2 \mathrm{~mL}$, and $n$-pentane $(15 \mathrm{ml})$ was added. The suspension was filtered, and the solid was washed with $n$-pentane $(2 \times 5 \mathrm{~mL})$, and air-dried to give a second crop of complex $\mathbf{4 a}$ as a pale yellow solid (72 mg). Yield: $102 \mathrm{mg}, 0.20 \mathrm{mmol}, 76 \%$. Mp: 115 ${ }^{\circ} \mathrm{C}$. Anal. Calcd for $\mathrm{C}_{19} \mathrm{H}_{21} \mathrm{BrN}_{2} \mathrm{O}_{3} \mathrm{Pd}$ (511.712): C, 44.60; H, 4.14; N, 5.47. Found: C, 44.97; H, 3.89; N, 5.49. IR $\left(\mathrm{cm}^{-1}\right): v(\mathrm{NH}) 3304 \mathrm{v}$ br; $v(\mathrm{CN}) 2189 \mathrm{~s} ; v(\mathrm{CO}) 1735 \mathrm{~s} .{ }^{1} \mathrm{H}$ NMR $(400.91 \mathrm{MHz}): \delta 2.40(\mathrm{~s}, 6 \mathrm{H}$, $\mathrm{Me}, \mathrm{Xy}), 3.15\left(\mathrm{dd}, 1 \mathrm{H}, \mathrm{CH}_{2},{ }^{2} J_{\mathrm{HH}}=14.0,{ }^{3} J_{\mathrm{HH}}=4.8 \mathrm{~Hz}\right), 3.37\left(\mathrm{dd}, 1 \mathrm{H}, \mathrm{CH}_{2},{ }^{2} J_{\mathrm{HH}}=14.0,{ }^{3} J_{\mathrm{HH}}=4.0 \mathrm{~Hz}\right)$, 3.63 (br m, $1 \mathrm{H}, \mathrm{CH}), 3.71$ (s, $3 \mathrm{H}, \mathrm{OMe}$ ), 3.88 (br m, $1 \mathrm{H}, \mathrm{NH}_{2}$ ), 4.20 (br m, $1 \mathrm{H}, \mathrm{NH}_{2}$ ), 5.20 (br s, $1 \mathrm{H}$, $\mathrm{OH}), 6.51\left(\mathrm{dd}, 1 \mathrm{H}, \mathrm{H} 3,{ }^{3} J_{\mathrm{HH}}=8.0,{ }^{4} J_{\mathrm{HH}}=2.8 \mathrm{~Hz}\right), 6.84\left(\mathrm{~d}, 1 \mathrm{H}, \mathrm{H} 2,{ }^{3} J_{\mathrm{HH}}=8.0 \mathrm{~Hz}\right), 7.07(\mathrm{~d}, 2 \mathrm{H}, m-\mathrm{H}$, $\left.\mathrm{Xy},{ }^{3} J_{\mathrm{HH}}=7.6 \mathrm{~Hz}\right), 7.09\left(\mathrm{~d}, 1 \mathrm{H}, \mathrm{H} 5,{ }^{4} J_{\mathrm{HH}}=2.4 \mathrm{~Hz}\right), 7.21\left(\mathrm{t}, 1 \mathrm{H}, p-\mathrm{H}, \mathrm{Xy},{ }^{3} J_{\mathrm{HH}}=7.6 \mathrm{~Hz}\right) .{ }^{13} \mathrm{C} \mathrm{NMR}$ (75.45 MHz): $\delta 18.9$ (s, Me, Xy), $44.3\left(\mathrm{~s}, \mathrm{CH}_{2}\right), 50.2$ (s, CH), 53.1 (s, OMe), 112.1 (s, CH, C3), 125.0 (s, CH, C5), 127.9 (s, C1), 128.0 (s, m-CH, Xy), 128.5 (s, CH, C2), 129.7 (s, p-CH, Xy), 136.0 (s, o-C, Xy), 146.5 (s, C6, C-Pd), 152.6 (s, C4, C-OH), 172.0 (s, CO). The resonances of the $i$-C of Xy and CN were not observed. $[\alpha]_{\mathrm{D}}^{20}=+5.36\left(\mathrm{c}=0.20, \mathrm{CH}_{2} \mathrm{Cl}_{2}\right)$.

\section{Synthesis of $\left[\mathrm{Pd}\left\{C, N-\mathrm{C}(=\mathrm{NXy})-\mathrm{C}_{6} \mathrm{H}_{2} \mathrm{CH}_{2} \mathrm{CH}_{2} \mathrm{NH}_{2}-6,(\mathrm{OMe})_{2}-3,4\right\} \mathrm{Br}(\mathrm{CNXy})\right](5 \mathrm{~b})$. XyNC (71.6 mg,} $0.55 \mathrm{mmol}$ ) was added to a suspension of complex $\mathbf{1 b}-\mathbf{B r} \cdot \mathrm{H}_{2} \mathrm{O}(100 \mathrm{mg}, 0.13 \mathrm{mmol})$ in $\mathrm{CH}_{2} \mathrm{Cl}_{2}(25 \mathrm{ml})$, and the resulting solution was was stirred for $4 \mathrm{~h}$. The mixture was filtered through a plug of $\mathrm{MgSO}_{4}$, the filtrate was concentrated to ca. $2 \mathrm{~mL}$, and $\mathrm{Et}_{2} \mathrm{O}(15 \mathrm{ml})$ was added. The suspension was filtered, and the solid was washed with $\mathrm{Et}_{2} \mathrm{O}(2 \times 5 \mathrm{~mL})$ and air-dried to give a first crop of complex $\mathbf{5 b}(83 \mathrm{mg})$. The 
filtrate was concentrated to ca. $2 \mathrm{~mL}$, and $n$-pentane $(15 \mathrm{ml})$ was added. The suspension was filtered, and the solid was washed with $n$-pentane $(2 \times 5 \mathrm{~mL})$ and air-dried to give a second crop of complex $\mathbf{5 b}$

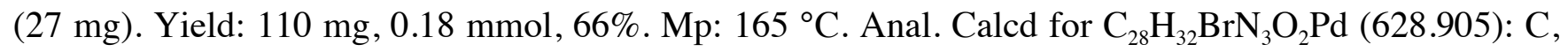
53.47; H, 5.13; N, 6.68. Found: C, 53.37; H, 5.03; N, 6.93. IR $\left(\mathrm{cm}^{-1}\right): v(\mathrm{NH}) 3263 \mathrm{~m}, 3228 \mathrm{~m}, 3153 \mathrm{w}$; $v(\mathrm{CN}) 2177 \mathrm{~s} ; v(\mathrm{C}=\mathrm{N}) 1629$ s. ${ }^{1} \mathrm{H}$ NMR (400.91 MHz): $\delta 2.16$ (s, $\left.6 \mathrm{H}, \mathrm{Me}, \mathrm{Xy}\right), 2.18$ (s, $\left.6 \mathrm{H}, \mathrm{Me}, \mathrm{Xy}\right)$, 2.93 (br s, $2 \mathrm{H}, \mathrm{NH}_{2}$ ), 3.24 (quint, $1 \mathrm{H}, \mathrm{CH}_{2} \mathrm{~N},{ }^{3} \mathrm{~J}_{\mathrm{HH}}=6.0 \mathrm{~Hz}$ ), $3.80\left(\right.$ (ct”, $2 \mathrm{H}, \mathrm{CH}_{2} \mathrm{Ar},{ }^{3} J_{\mathrm{HH}}=5.6 \mathrm{~Hz}$ ), 3.91 (s, $3 \mathrm{H}, \mathrm{OMe}), 3.94(\mathrm{~s}, 3 \mathrm{H}, \mathrm{OMe}), 6.68(\mathrm{~s}, 1 \mathrm{H}, \mathrm{H} 2), 6.79\left(\mathrm{dd}, 1 \mathrm{H}, p-\mathrm{H}\right.$, coordinated Xy, ${ }^{3} J_{\mathrm{HH}}=8.0$, $\left.{ }^{3} J_{\mathrm{HH}}=6.4 \mathrm{~Hz}\right), 6.87\left(\mathrm{~d}, 2 \mathrm{H}, m-\mathrm{H}\right.$, coordinated Xy, $\left.{ }^{3} J_{\mathrm{HH}}=7.6 \mathrm{~Hz}\right), 7.02\left(\mathrm{~d}, 2 \mathrm{H}, m-\mathrm{H}\right.$, inserted Xy, ${ }^{3} J_{\mathrm{HH}}=$ $7.6 \mathrm{~Hz}), 7.17\left(\mathrm{t}, 1 \mathrm{H}, p-\mathrm{H}\right.$, inserted $\left.\mathrm{Xy},{ }^{3} J_{\mathrm{HH}}=7.6 \mathrm{~Hz}\right), 7.60(\mathrm{~s}, 1 \mathrm{H}, \mathrm{H} 5),{ }^{13} \mathrm{C}$ NMR $(100.81 \mathrm{MHz}): \delta$ 18.7 (s, Me, Xy), 19.4 (s, Me, Xy), 37.2 (s, $\mathrm{CH}_{2} \mathrm{Ar}$ ), 43.3 (s, $\mathrm{CH}_{2} \mathrm{~N}$ ), 56.0 (s, OMe), 56.1 (s, OMe), 110.7 (s, CH, C5), 113.0 (s, CH, C2), 123.1 (s, p-CH, coordinated Xy), 126.5 (s, o-C, coordinated Xy), 127.5 (s, $m$-CH, inserted Xy), 128.0 (s, m-CH, coordinated Xy), 129.3 (s, p-CH, inserted Xy), 129.4 (s, C1), 132.0 (s, C6), 135.1 (s, o-C, inserted Xy), 148.0 (s, C4), 150.5 (s, C3), 151.4 (s, $i$-C, coordinated $\mathrm{Xy}), 174.9$ (s, CN, inserted $\mathrm{Xy}$ ). The ${ }^{13} \mathrm{C}$ resonances corresponding to $i$-C of the inserted $\mathrm{Xy}$ and $\mathrm{CN}$ of the coordinated Xy were not observed.

Synthesis of $\left[\mathrm{Pd}(\mathrm{OAc})_{2}\left\{\mathrm{NH}_{2} \mathrm{CH}_{2} \mathrm{CH}_{2} \mathrm{C}_{6} \mathrm{H}_{3}(\mathrm{OMe})_{2}-3,4\right\}_{2}\right]$ (6b-OAc). Homoveratrylamine (1 mL, $6.02 \mathrm{mmol})$ was added to a suspension of $\mathrm{Pd}(\mathrm{OAc})_{2}(675.6 \mathrm{mg}, 3.01 \mathrm{mmol})$ in acetone $(50 \mathrm{~mL})$, and the resulting mixture was stirred for $16 \mathrm{~h}$. The suspension was filtered, and the solid was washed with $\mathrm{Et}_{2} \mathrm{O}$ $(2 \times 5 \mathrm{~mL})$ and air-dried to give complex 6b-OAc $\cdot \mathrm{H}_{2} \mathrm{O}$ as a yellow solid (1415 mg). Yield: $1415.1 \mathrm{mg}$, $2.34 \mathrm{mmol}, 78 \%$. The crystallization water can be removed by heating the sample at $60{ }^{\circ} \mathrm{C}$ for $2 \mathrm{~h}$ in a vacuum oven. Mp: $145^{\circ} \mathrm{C}$. Anal. Calcd for $\mathrm{C}_{24} \mathrm{H}_{36} \mathrm{~N}_{2} \mathrm{O}_{8} \mathrm{Pd}$ (586.971): C, 49.11; H, 6.18; N, 4.77. Found: $\mathrm{C}, 48.92 ; \mathrm{H}, 6.22 ; \mathrm{N}, 4.92 . \mathrm{IR}\left(\mathrm{cm}^{-1}\right): v(\mathrm{NH}) 3244 \mathrm{~m}, 3200 \mathrm{~m}, 3119 \mathrm{~m} ; v(\mathrm{CO})_{\mathrm{OAc}} 1566 \mathrm{~s} .{ }^{1} \mathrm{H}$ NMR (200.13 MHz): $\delta 1.86$ (s, $3 \mathrm{H}, \mathrm{Me}, \mathrm{OAc}$ ), 2.79 (quint, $2 \mathrm{H}, \mathrm{CH}_{2} \mathrm{~N},{ }^{3} \mathrm{~J}_{\mathrm{HH}}=6.8 \mathrm{~Hz}$ ), 2.92 (“t”, $2 \mathrm{H}, \mathrm{NH}_{2} \mathrm{Ar}$, $\left.{ }^{3} J_{\mathrm{HH}}=6.8 \mathrm{~Hz}\right), 3.67\left(\mathrm{~m}, 2 \mathrm{H}, \mathrm{NH}_{2}\right), 3.86(\mathrm{~s}, 3 \mathrm{H}, \mathrm{OMe}), 3.88(\mathrm{~s}, 3 \mathrm{H}, \mathrm{OMe}), 6.72(\mathrm{~A}$ part of an $\mathrm{ABC}$ system, $\left.1 \mathrm{H}, \mathrm{H} 2,{ }^{4} J_{\mathrm{AB}}=2.0 \mathrm{~Hz}\right), 6.75\left(\mathrm{~B}\right.$ part of an $\mathrm{ABC}$ system, $\left.1 \mathrm{H}, \mathrm{H} 6,{ }^{3} J_{\mathrm{BC}}=8.0,{ }^{4} J_{\mathrm{AB}}=2.0 \mathrm{~Hz}\right), 6.80$ 
(C part of an ABC system, $\left.1 \mathrm{H}, \mathrm{H} 5,{ }^{3} J_{\mathrm{BC}}=8.0 \mathrm{~Hz}\right) \cdot{ }^{13} \mathrm{C}$ NMR $(50.3 \mathrm{MHz}): \delta 23.4(\mathrm{~s}, \mathrm{Me}, \mathrm{OAc}), 36.5(\mathrm{~s}$, $\left.\mathrm{CH}_{2} \mathrm{Ar}\right), 44.7\left(\mathrm{~s}, \mathrm{CH}_{2} \mathrm{~N}\right), 55.8(\mathrm{~s}, \mathrm{OMe}), 55.9$ (s, OMe), $111.4(\mathrm{~s}, \mathrm{CH}, \mathrm{C} 5), 111.8$ (s, CH, C2), 120.7 (s, CH, C6), 130.0 (s, C1), 147.8 (s, C4, C-OMe), 149.1 (s, C3, C-OMe), 179.9 (s, CO). Single crystals suitable for an X-ray diffraction study were obtained by slow diffusion of $n$-pentane into a solution of 6b-OAc $\cdot \mathrm{H}_{2} \mathrm{O}$ in $\mathrm{CH}_{2} \mathrm{Cl}_{2}$.

Synthesis of $\left[\mathrm{PdBr}_{2}\left\{\mathrm{NH}_{2} \mathrm{CH}_{2} \mathrm{CH}_{2} \mathbf{C}_{6} \mathbf{H}_{3}(\mathbf{O M e})_{2}-\mathbf{3 , 4}\right\}_{2}\right]$ (6b-Br). $\mathrm{NaBr}$ (500 mg, $\left.4.859 \mathrm{mmol}\right)$ was added to a suspension of complex $\mathbf{6 b - O A c} \cdot \mathrm{H}_{2} \mathrm{O}(500 \mathrm{mg}, 0.826 \mathrm{mmol})$ in acetone $(50 \mathrm{ml})$, and the resulting suspension was stirred for $16 \mathrm{~h}$. The solvent was removed, $\mathrm{CH}_{2} \mathrm{Cl}_{2}$ (40 mL) was added, and the mixture was filtered through a plug of Celite. The filtrate was concentrated to ca. $2 \mathrm{~mL}$, and $\mathrm{Et}_{2} \mathrm{O}$ (30 $\mathrm{mL})$ was added. The suspension was filtered, and the solid was washed with $\mathrm{Et}_{2} \mathrm{O}(2 \times 5 \mathrm{~mL})$ and airdried to give complex $\mathbf{6 b - B r}$ as a yellow solid. Yield: $479 \mathrm{mg}, 0.76 \mathrm{mmol}, 92 \% . \mathrm{Mp}: 148{ }^{\circ} \mathrm{C}$. Anal. Calcd for $\mathrm{C}_{20} \mathrm{H}_{30} \mathrm{Br}_{2} \mathrm{~N}_{2} \mathrm{O}_{4} \mathrm{Pd}$ (628.698): C, 38.21; H, 4.81; N, 4.46. Found: C, 38.18; H, 5.00; N, 4.34. IR $\left(\mathrm{cm}^{-1}\right): v(\mathrm{NH}) 3275 \mathrm{~s}, 3213 \mathrm{~s}, 3213 \mathrm{~m} .{ }^{1} \mathrm{H} \mathrm{NMR}(400.91 \mathrm{MHz}): \delta 2.63\left(\mathrm{br} \mathrm{t}, 2 \mathrm{H}, \mathrm{NH}_{2},{ }^{3} J_{\mathrm{HH}}=6.8 \mathrm{~Hz}\right)$ $2.83\left(\mathrm{t}, 2 \mathrm{H}, \mathrm{CH}_{2} \mathrm{Ar},{ }^{3} J_{\mathrm{HH}}=6.8 \mathrm{~Hz}\right), 3.08$ (quint, $\left.2 \mathrm{H}, \mathrm{CH}_{2} \mathrm{~N},{ }^{3} J_{\mathrm{HH}}=6.8 \mathrm{~Hz}\right), 3.86(\mathrm{~s}, 3 \mathrm{H}, \mathrm{OMe}), 3.90(\mathrm{~s}$, $3 \mathrm{H}, \mathrm{OMe}$ ), 6.73 (A part of an $\mathrm{ABC}$ system, $\left.1 \mathrm{H}, \mathrm{H} 2,{ }^{4} J_{\mathrm{AB}}=2.0 \mathrm{~Hz}\right), 6.73(\mathrm{~B}$ part of an $\mathrm{ABC}$ system, 1 $\left.\mathrm{H}, \mathrm{H} 6,{ }^{3} J_{\mathrm{BC}}=8.0,{ }^{4} J_{\mathrm{AB}}=2.0 \mathrm{~Hz}\right), 6.81\left(\mathrm{C}\right.$ part of an $\mathrm{ABC}$ system, $\left.1 \mathrm{H}, \mathrm{H} 5,{ }^{3} J_{\mathrm{BC}}=8.0 \mathrm{~Hz}\right) .{ }^{13} \mathrm{C} \mathrm{NMR}$ (100.81 MHz): $\delta 37.1\left(\mathrm{~s}, \mathrm{CH}_{2} \mathrm{Ar}\right), 44.7\left(\mathrm{~s}, \mathrm{CH}_{2} \mathrm{~N}\right), 55.9(\mathrm{~s}, \mathrm{OMe}), 55.9$ (s, OMe), $111.5\left(\mathrm{~s}, \mathrm{CH}_{6} \mathrm{C}_{6} \mathrm{H}_{3}\right)$, 111.6 (s, CH, $\mathrm{C}_{6} \mathrm{H}_{3}$ ), 120.9 (s, CH, $\mathrm{C}_{6} \mathrm{H}_{3}$ ), 129.1 (s, C1), 148.0 (s, C-OMe), 149.2 (s, C-OMe). Single crystals suitable for an X-ray diffraction study were obtained by slow diffusion of $\mathrm{Et}_{2} \mathrm{O}$ into a solution of $\mathbf{6 b}-\mathbf{B r}$ in $\mathrm{CH}_{2} \mathrm{Cl}_{2}$.

Synthesis of $\left[\mathrm{Pd}(\mathrm{OAc})_{2}\left\{\mathrm{NH}_{2} \mathrm{CH}_{2} \mathrm{CH}_{2} \mathrm{C}_{6} \mathrm{H}_{3}(\mathrm{OMe})_{2}-3,4\right\} \mathrm{PPh}_{3}\right] \cdot \mathrm{H}_{2} \mathrm{O}\left(7 \mathrm{~b}-\mathrm{OAc} \cdot \mathrm{H}_{2} \mathrm{O}\right)$. Method A. $\mathrm{PPh}_{3}$ (89 mg, $0.34 \mathrm{mmol}$ ) was added to a suspension of complex 6b-OAc $\cdot \mathrm{H}_{2} \mathrm{O}(200 \mathrm{mg}, 0.33 \mathrm{mmol})$ in $\mathrm{CH}_{2} \mathrm{Cl}_{2}(30 \mathrm{~mL})$, and the resulting solution was stirred for $1 \mathrm{~h}$. The mixture was filtered through a plug of Celite, the filtrate was concentrated to ca. $2 \mathrm{~mL}$, and $n$-pentane $(30 \mathrm{~mL})$ was added. The suspension was filtered, and the solid was washed with $n$-pentane $(2 \times 5 \mathrm{~mL})$ and air-dried to give complex $7 \mathbf{b}$ - 
OAc $\cdot \mathrm{H}_{2} \mathrm{O}$ as a yellow solid. Yield: $121 \mathrm{mg}, 0.18 \mathrm{mmol}, 53 \%$. Method B. $\mathrm{PPh}_{3}(129 \mathrm{mg}, 0.49 \mathrm{mmol})$ was added to a solution of complex $\mathbf{8 b}(100 \mathrm{mg}, 0.25 \mathrm{mmol})$ in $\mathrm{CH}_{2} \mathrm{Cl}_{2}(30 \mathrm{~mL})$, and the resulting solution was stirred for $1 \mathrm{~h}$. The mixture was filtered through a plug of Celite, the filtrate was concentrated to ca. $2 \mathrm{~mL}$, and $\mathrm{Et}_{2} \mathrm{O}(15 \mathrm{~mL})$ was added. The suspension was filtered, and the solid was washed with $\mathrm{Et}_{2} \mathrm{O}(2 \times 5 \mathrm{~mL})$ and air-dried to give a first crop of complex $7 \mathbf{b}-\mathbf{O A c} \cdot \mathrm{H}_{2} \mathrm{O}(153 \mathrm{mg})$. The filtrate was concentrated to ca. $2 \mathrm{~mL}$ and $n$-pentane $(30 \mathrm{~mL})$ was added. The suspension was filtered, and the solid was washed with $n$-pentane $(2 \times 5 \mathrm{~mL})$ and air-dried to give a second crop of complex $7 \mathbf{b}$ OAc $\cdot \mathrm{H}_{2} \mathrm{O}(48 \mathrm{mg})$. Yield: $201 \mathrm{mg}, 0.29 \mathrm{mmol}, 60 \%$. Mp: $126{ }^{\circ} \mathrm{C}$. Anal. Calcd for $\mathrm{C}_{32} \mathrm{H}_{36} \mathrm{NO}_{6} \mathrm{PPd} \cdot \mathrm{H}_{2} \mathrm{O}$ (686.03): C, 56.02; H, 5.58; N, 2.04. Found: C, 56.12; H, 5.54; N, 2.14. IR (cm $\left.{ }^{-1}\right): v(\mathrm{NH}) 3229 \mathrm{~m}, 3139$ m; $v(\mathrm{CO})_{\mathrm{OAc}} 1633$ vs. ${ }^{1} \mathrm{H}$ NMR (400.91 MHz): $\delta 1.42$ (s, $\left.6 \mathrm{H}, \mathrm{Me}, \mathrm{OAc}\right), 1.86$ (br s, $\left.2 \mathrm{H}, \mathrm{H}_{2} \mathrm{O}\right), 2.90$ (“t”, $\left.2 \mathrm{H}, \mathrm{CH}_{2} \mathrm{Ar},{ }^{3} J_{\mathrm{HP}}=6.4 \mathrm{~Hz}\right), 2.97\left(\mathrm{~m}, 2 \mathrm{H}, \mathrm{CH}_{2} \mathrm{~N}\right), 3.79\left(\mathrm{~m}, 2 \mathrm{H}, \mathrm{NH}_{2}\right), 3.84(\mathrm{~s}, 3 \mathrm{H}, \mathrm{OMe}), 3.85$ (s, $3 \mathrm{H}, \mathrm{OMe}), 6.72\left(\mathrm{C}\right.$ part of an $\mathrm{ABC}$ system, $\left.1 \mathrm{H}, \mathrm{H} 2,{ }^{4} J_{\mathrm{BC}}=1.8 \mathrm{~Hz}\right), 6.74(\mathrm{~B}$ part of an $\mathrm{ABC}$ system, 1 $\left.\mathrm{H}, \mathrm{H} 6,{ }^{3} J_{\mathrm{AB}}=7.9,{ }^{4} J_{\mathrm{BC}}=1.8 \mathrm{~Hz}\right), 6.78\left(\mathrm{~A}\right.$ part of an ABC system, $\left.1 \mathrm{H}, \mathrm{H} 5,{ }^{3} J_{\mathrm{AB}}=7.9 \mathrm{~Hz}\right), 7.39-7.44(\mathrm{~m}$, $\left.6 \mathrm{H}, m-\mathrm{H}, \mathrm{PPh}_{3}\right), 7.48-7.52\left(\mathrm{~m}, 3 \mathrm{H}, p-\mathrm{H}, \mathrm{PPh}_{3}\right), 7.69-7.75\left(\mathrm{~m}, 6 \mathrm{H}, o-\mathrm{H}, \mathrm{PPh}_{3}\right) .{ }^{13} \mathrm{C} \mathrm{NMR}(75.45 \mathrm{MHz}):$

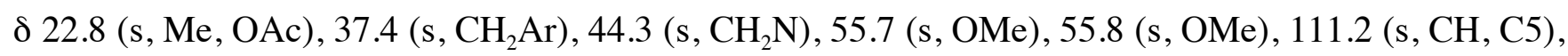
$111.8(\mathrm{~s}, \mathrm{CH}, \mathrm{C} 2), 120.7(\mathrm{~s}, \mathrm{CH}, \mathrm{C} 6), 127.7\left(\mathrm{~d}, i-\mathrm{C}, \mathrm{PPh}_{3},{ }^{1} J_{\mathrm{CP}}=52.1 \mathrm{~Hz}\right), 128.4\left(\mathrm{~d}, m-\mathrm{CH}, \mathrm{PPh}_{3},{ }^{3} J_{\mathrm{CP}}=\right.$ $11.0 \mathrm{~Hz}), 130.9\left(\mathrm{~d}, p-\mathrm{CH}, \mathrm{PPh}_{3},{ }^{4} J_{\mathrm{CP}}=2.7 \mathrm{~Hz}\right), 130.5(\mathrm{~s}, \mathrm{C} 1), 134.3\left(\mathrm{~d}, o-\mathrm{CH}, \mathrm{PPh}_{3},{ }^{2} J_{\mathrm{CP}}=11.0 \mathrm{~Hz}\right)$, 147.6 (s, C-OMe), 148.9 (s, C-OMe), 178.1 (s, CO). ${ }^{31} \mathrm{P}$ NMR (121.5 MHz): $\delta 21.3\left(\mathrm{~s}, \mathrm{PPh}_{3}\right)$. Single crystals of $7 \mathbf{b}$-OAc, suitable for an X-ray diffraction study, were obtained by slow diffusion of $\mathrm{Et}_{2} \mathrm{O}$ into a solution of $\mathbf{7 b - O A c} \cdot \mathrm{H}_{2} \mathrm{O}$ in $\mathrm{CHCl}_{3}$.

Synthesis of $\left[\mathbf{P d B r}_{2}\left\{\mathrm{NH}_{2} \mathrm{CH}_{2} \mathrm{CH}_{2} \mathrm{C}_{6} \mathrm{H}_{3}(\mathbf{O M e})_{2}-\mathbf{3}, \mathbf{4}\right\} \mathbf{P P h}\right]$ (7b-Br). $\mathrm{PPh}_{3}(42 \mathrm{mg}, 0.16 \mathrm{mmol})$ was added to a suspension of complex $\mathbf{6 b}-\mathbf{B r}(100 \mathrm{mg}, 0.16 \mathrm{mmol})$ in $\mathrm{CH}_{2} \mathrm{Cl}_{2}(30 \mathrm{~mL})$, and the resulting solution was stirred for $1 \mathrm{~h}$. The mixture was filtered through a plug of Celite, the filtrate was concentrated to ca. $2 \mathrm{~mL}$, and $\mathrm{Et}_{2} \mathrm{O}(30 \mathrm{~mL})$ was added. The suspension was filtered, and the solid was washed with $\mathrm{Et}_{2} \mathrm{O}(2 \times 5 \mathrm{~mL})$ and air-dried to give a first crop of complex $\mathbf{7 b}-\mathbf{B r}$ as an orange solid (48 
$\mathrm{mg})$. The filtrate was concentrated to ca. $2 \mathrm{~mL}$ and $n$-pentane $(30 \mathrm{~mL})$ was added. The suspension was filtered, and the solid was washed with $n$-pentane $(2 \times 5 \mathrm{~mL})$ and air-dried to give a second crop of complex 7b-Br as an orange solid (53 mg). Yield: $101 \mathrm{mg}, 0.14 \mathrm{mmol}, 89 \%$. Mp: $163{ }^{\circ} \mathrm{C}$. Anal. Calcd for $\mathrm{C}_{28} \mathrm{H}_{30} \mathrm{Br}_{2} \mathrm{NO}_{2} \mathrm{PPd}$ (709.755): C, 47.38; H, 4.26; N, 1.97. Found: C, 47.30; H, 4.13; N, 2.01. IR (cm $\left.{ }^{1}\right): v(\mathrm{NH}) 3283$ s, 3240 s, 3146 m. ${ }^{1} \mathrm{H}$ NMR (400.91 MHz): $\delta 2.76$ (m, 2 H, $\mathrm{NH}_{2}$ ), 2.88 (“'t”, 2 H, $\mathrm{CH}_{2} \mathrm{Ar}$, $\left.{ }^{3} J_{\mathrm{HP}}=6.8 \mathrm{~Hz}\right), 3.33\left(\mathrm{~m}, 2 \mathrm{H}, \mathrm{CH}_{2} \mathrm{~N}\right), 3.85(\mathrm{~s}, 3 \mathrm{H}, \mathrm{OMe}), 3.87(\mathrm{~s}, 3 \mathrm{H}, \mathrm{OMe}), 6.76(\mathrm{~B}$ part of an $\mathrm{ABC}$ system, $1 \mathrm{H}, \mathrm{H} 6,{ }^{3} J_{\mathrm{AB}}=8.0,{ }^{4} J_{\mathrm{BC}}=1.8 \mathrm{~Hz}$ ), 6.76 (A part of an $\mathrm{ABC}$ system, $1 \mathrm{H}, \mathrm{H} 2,{ }^{4} J_{\mathrm{AB}}=1.8 \mathrm{~Hz}$ ), $6.80\left(\mathrm{C}\right.$ part of an ABC system, $\left.1 \mathrm{H}, \mathrm{H} 5,{ }^{3} J_{\mathrm{BC}}=8.0 \mathrm{~Hz}\right), 7.38-7.48\left(\mathrm{~m}, 9 \mathrm{H}, m-\mathrm{H}+p-\mathrm{H}, \mathrm{PPh}_{3}\right), 7.69-$ $7.74\left(\mathrm{~m}, 6 \mathrm{H}, o-\mathrm{H}, \mathrm{PPh}_{3}\right) .{ }^{13} \mathrm{C} \mathrm{NMR}(75.45 \mathrm{MHz}): \delta 37.8\left(\mathrm{~d}, \mathrm{CH}_{2} \mathrm{Ar},{ }^{3} J_{\mathrm{CP}}=3.2 \mathrm{~Hz}\right), 44.8\left(\mathrm{~d}, \mathrm{CH}_{2} \mathrm{~N},{ }^{3} J_{\mathrm{CP}}\right.$ = 2.6 Hz), $55.9(\mathrm{~s}, \mathrm{OMe}), 56.0(\mathrm{~s}, \mathrm{OMe}), 111.4(\mathrm{~s}, \mathrm{CH}, \mathrm{C} 5), 111.7(\mathrm{~s}, \mathrm{CH}, \mathrm{C} 2), 121.0(\mathrm{~s}, \mathrm{CH}, \mathrm{C} 6), 128.0$ (d, $\left.m-\mathrm{CH}, \mathrm{PPh}_{3},{ }^{3} J_{\mathrm{CP}}=11.2 \mathrm{~Hz}\right), 129.7(\mathrm{~s}, \mathrm{C} 1), 130.7$ (d, one-half of the doublet was obscured by the $p$ $\mathrm{CH}$ signal), $130.9\left(\mathrm{~d}, p-\mathrm{CH}, \mathrm{PPh}_{3},{ }^{4} J_{\mathrm{CP}}=2.5 \mathrm{~Hz}\right), 134.8\left(\mathrm{~d}, o-\mathrm{CH}, \mathrm{PPh}_{3},{ }^{2} J_{\mathrm{CP}}=10.5 \mathrm{~Hz}\right), 147.9(\mathrm{~s}, C-$ OMe), 149.2 (s, $C-\mathrm{OMe}) .{ }^{31} \mathrm{P}$ NMR (162.29 MHz): $\delta 28.0\left(\mathrm{~s}, \mathrm{PPh}_{3}\right)$.

\section{Synthesis of $\left[\mathrm{Pd}_{2}(\mu-\mathrm{OAc})_{2}(\mathrm{OAc})_{2}\left\{\mathrm{NH}_{2} \mathrm{CH}_{2} \mathrm{CH}_{2} \mathrm{C}_{6} \mathrm{H}_{3}(\mathrm{OMe})_{2}-\mathbf{3 , 4}\right\}_{2}\right]$ (8b). Homoveratrylamine (273}

$\mathrm{mg}, 1.51 \mathrm{mmol})$ was added to a suspension of $\mathrm{Pd}(\mathrm{OAc})_{2}(338 \mathrm{mg}, 1.51 \mathrm{mmol})$ in $\mathrm{CH}_{2} \mathrm{Cl}_{2}(30 \mathrm{~mL})$, and the mixture was stirred for $1 \mathrm{~h}$. The resulting solution was concentrated to ca. $2 \mathrm{~mL}$, and $\mathrm{Et}_{2} \mathrm{O}(30 \mathrm{~mL})$ was added. The suspension was filtered, and the solid was washed with $\mathrm{Et}_{2} \mathrm{O}(2 \times 5 \mathrm{~mL})$ and air-dried to give complex 6b-OAc as a yellow solid (179 $\mathrm{mg}, 0.31 \mathrm{mmol}, 40 \%)$. The filtrate was concentrated to ca. $4 \mathrm{~mL}$ and $n$-hexane $(20 \mathrm{~mL})$ was added. The suspension was filtered, and the solid was washed with $n$ hexane (2 x $5 \mathrm{~mL})$ and air-dried to give complex $\mathbf{8 b}(214 \mathrm{mg}, 0.26 \mathrm{mmol})$ as an orange solid (214 $\mathrm{mg})$. Yield: $214 \mathrm{mg}, 0.26 \mathrm{mmol}, 35 \%$. Mp: $50{ }^{\circ} \mathrm{C}$. Anal. Calcd for $\mathrm{C}_{28} \mathrm{H}_{42} \mathrm{~N}_{2} \mathrm{O}_{12} \mathrm{Pd}_{2}$ (881.486): C, 41.44; $\mathrm{H}$, 5.22; N, 3.45. Found: C, 41.44; H, 5.41; N, 3.49. IR $\left(\mathrm{cm}^{-1}\right): v(\mathrm{CO})_{\mathrm{OAc}} 1631$ br, 1567 br. ${ }^{1} \mathrm{H}$ NMR (400.91 MHz): $\delta 1.88(\mathrm{~s}, 3 \mathrm{H}, \mathrm{Me}, \mathrm{OAc}), 1.89$ (s, $3 \mathrm{H}, \mathrm{Me}, \mathrm{OAc}$ ), 2.57 (quint, $1 \mathrm{H}, \mathrm{CH}_{2} \mathrm{~N},{ }^{3} J_{\mathrm{HH}}=6.4$ $\mathrm{Hz}$ ), 2.71 (quint, $1 \mathrm{H}, \mathrm{CH}_{2} \mathrm{~N},{ }^{3} J_{\mathrm{HH}}=6.4 \mathrm{~Hz}$ ), 3.19 (“'t”, $2 \mathrm{H}, \mathrm{CH}_{2} \mathrm{Ar},{ }^{3} J_{\mathrm{HH}}=6.8 \mathrm{~Hz}$ ), 3.86 (br m, $1 \mathrm{H}$, $\mathrm{NH}_{2}$ ), 3.86 (s, $\left.3 \mathrm{H}, \mathrm{OMe}\right), 3.91$ (s, $\left.3 \mathrm{H}, \mathrm{OMe}\right), 5.09$ (br m, $\left.1 \mathrm{H}, \mathrm{NH}_{2}\right), 6.84(\mathrm{C}$ part of an ABC system, 1 
$\left.\mathrm{H}, \mathrm{H} 5,{ }^{3} J_{\mathrm{BC}}=8.0 \mathrm{~Hz}\right), 6.89\left(\mathrm{~B}\right.$ part of an ABC system, $\left.1 \mathrm{H}, \mathrm{H} 6,{ }^{3} J_{\mathrm{AB}}=8.0,{ }^{4} J_{\mathrm{BC}}=1.6 \mathrm{~Hz}\right), 6.91(\mathrm{~A}$ part of an $\mathrm{ABC}$ system, $\left.1 \mathrm{H}, \mathrm{H} 2,{ }^{4} \mathrm{~J}_{\mathrm{AB}}=1.6 \mathrm{~Hz}\right) .{ }^{13} \mathrm{C} \mathrm{NMR}(100.81 \mathrm{MHz}): \delta 22.6(\mathrm{~s}, \mathrm{Me}, \mathrm{OAc}), 22.8(\mathrm{~s}, \mathrm{Me}$, OAc), $35.5\left(\mathrm{~s}, \mathrm{CH}_{2} \mathrm{Ar}\right), 44.4\left(\mathrm{~s}, \mathrm{CH}_{2} \mathrm{~N}\right), 55.5(\mathrm{~s}, \mathrm{OMe}), 55.6(\mathrm{~s}, \mathrm{OMe}), 111.2(\mathrm{~s}, \mathrm{CH}, \mathrm{C} 5), 111.9$ (s, $\mathrm{CH}$, C2), 120.6 (s, CH, C6), 129.8 (s, C1), 147.6 (s, C4, C-OMe), 148.8 (s, C3, C-OMe), 179.3 (s, CO), $185.2(\mathrm{~s}, \mathrm{CO})$.

\section{Synthesis of $\left[\mathrm{Pd}\left\{\mathrm{C}, \mathrm{N}-\mathrm{C}_{6} \mathrm{H}_{2} \mathrm{CH}_{2} \mathrm{CH}_{2} \mathrm{NH}_{2}-6,(\mathrm{OMe})_{2}-3,4\right\}(\right.$ tmeda) $] \mathrm{Br}$ (9b). To a suspension of} $\operatorname{Pd}(\mathrm{dba})_{2}(552.6 \mathrm{mg}, 0.96 \mathrm{mmol})$ in dry toluene $(20 \mathrm{~mL})$ was added tmeda $(111.7 \mathrm{mg}, 0.96 \mathrm{mmol})$, and the mixture was stirred for 10 min under a $\mathrm{N}_{2}$ atmosphere. 6-Bromo-3,4-dimethoxyphenethylemine (250 $\mathrm{mg}, 0.96 \mathrm{mmol}$ ) was then added, and the stirring was continued for $24 \mathrm{~h}$. The resulting suspension was filtered, and the solid was washed with $\mathrm{Et}_{2} \mathrm{O}(3 \times 5 \mathrm{~mL})$ and air-dried to give complex $\mathbf{9 b}$ as an ochre solid, which is contaminated with traces of metallic palladium. Complex $\mathbf{9 b}$ cannot be recrystallized to obtain a satisfactory elemental analysis, because it is very insoluble in most common solvents. Yield: $333.1 \mathrm{mg}, 0.69 \mathrm{mmol}, 72 \% . \mathrm{Mp}: 173-176^{\circ} \mathrm{C}$. Anal. Calcd for $\mathrm{C}_{16} \mathrm{H}_{30} \mathrm{BrN}_{3} \mathrm{O}_{2} \mathrm{Pd}$ (482.752): C, 39.81; $\mathrm{H}$, 6.26; N, 8.70. Found: C, 39.34; H, 5.99; N, 7.68. IR $\left(\mathrm{cm}^{-1}\right): v(\mathrm{NH}) 3185 \mathrm{~m}, 3086 \mathrm{~s} .{ }^{1} \mathrm{H}$ NMR (400.91 MHz, DMSO- $\left.d_{6}\right): \delta 2.53(\mathrm{~s}, 6 \mathrm{H}, \mathrm{MeN}), 2.59(\mathrm{~s}, 6 \mathrm{H}, \mathrm{MeN}), 2.63\left(\mathrm{~m}, 2 \mathrm{H}, \mathrm{CH}_{2}\right.$, tmeda), $2.81(\mathrm{~m}, 2 \mathrm{H}$, $\mathrm{CH}_{2}$, tmeda), $3.06\left(\mathrm{~m}, 2 \mathrm{H}, \mathrm{CH}_{2} \mathrm{Ar}\right), 3.65$ (s, $\left.3 \mathrm{H}, \mathrm{OMe}\right), 3.66$ (m, partially obscured by the signal of OMe, $\left.2 \mathrm{H}, \mathrm{CH}_{2} \mathrm{~N}\right), 3.74$ (s, $\left.3 \mathrm{H}, \mathrm{OMe}\right), 4.30\left(\mathrm{~m}, 2 \mathrm{H}, \mathrm{NH}_{2}\right), 6.62(\mathrm{~s}, 1 \mathrm{H}, \mathrm{H} 2), 6.77$ (s, $\left.1 \mathrm{H}, \mathrm{H} 5\right) .{ }^{13} \mathrm{C}$ NMR (50.30 MHz, DMSO-d $\left.)_{6}\right): \delta 38.4\left(\mathrm{~s}, \mathrm{CH}_{2} \mathrm{Ar}\right), 41.2\left(\mathrm{~s}, \mathrm{CH}_{2} \mathrm{~N}\right), 47.4(\mathrm{~s}, \mathrm{MeN}), 50.2(\mathrm{~s}, \mathrm{MeN}), 55.7$ (s, OMe), 55.9 (s, OMe), 58.1 (s, $\mathrm{CH}_{2}$, tmeda), 62.2 (s, $\mathrm{CH}_{2}$, tmeda), 110.9 (s, CH, C2), 115.9 (s, $\mathrm{CH}$, C5), 132.2 (s, C1), 139.8 (s, C6), 145.2 (s, C4), 146.3 (s, C3).

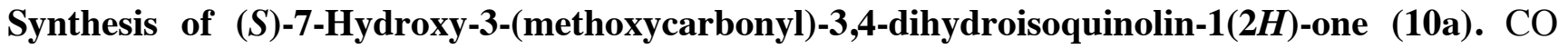

was bubbled through a suspension of complex $\mathbf{1 a - B r}(150 \mathrm{mg}, 0.20 \mathrm{mmol})$ in $\mathrm{CH}_{2} \mathrm{Cl}_{2}(20 \mathrm{~mL})$, and the resulting mixture was stirred under a $\mathrm{CO}$ atmosphere for $16 \mathrm{~h}$. Decomposition to metallic palladium was observed. The mixture was filtered through a plug of $\mathrm{MgSO}_{4}$, the filtrate was concentrated to ca. $2 \mathrm{~mL}$, and $\mathrm{Et}_{2} \mathrm{O}(30 \mathrm{~mL})$ was added. The suspension was filtered, and the solid was washed with $\mathrm{Et}_{2} \mathrm{O}(2 \times 5$ 
$\mathrm{mL}$ ) and air-dried to give crude compound 10a as a pale yellow solid. Yield: $37 \mathrm{mg}, 0.17 \mathrm{mmol}, 43 \%$. A spectroscopically pure sample of $\mathbf{1 0 a}$ was obtained by recrystallization from $\mathrm{CH}_{2} \mathrm{Cl}_{2} / \mathrm{Et}_{2} \mathrm{O}$. Mp: $143{ }^{\circ} \mathrm{C}$ dec. IR $\left(\mathrm{cm}^{-1}\right): v(\mathrm{NH}) 3302 \mathrm{w} ; v(\mathrm{CO}) 1722 \mathrm{~m} ; v(\mathrm{CO})_{\mathrm{CON}} 1667 \mathrm{~m} .{ }^{1} \mathrm{H}$ NMR (300.1 MHz, acetone- $\left.d_{6}\right): \delta$ 3.13, 3.29 (part $\mathrm{AB}$ of an $\mathrm{ABX}$ system, $2 \mathrm{H}, \mathrm{CH}_{2},{ }^{2} J_{\mathrm{AB}}=15.8,{ }^{3} J_{\mathrm{AX}}=6.1,{ }^{3} J_{\mathrm{BX}}=5.3 \mathrm{~Hz}$ ), $3.64(\mathrm{~s}, 3 \mathrm{H}$, $\mathrm{OMe}$ ), 4.42 (part X of an ABX system, $1 \mathrm{H}, \mathrm{CH}), 6.94\left(\mathrm{dd}, 1 \mathrm{H}, \mathrm{H} 6,{ }^{3} J_{\mathrm{HH}}=8.1,{ }^{4} J_{\mathrm{HH}}=2.7 \mathrm{~Hz}\right), 7.07(\mathrm{br}$ $\mathrm{s}, 1 \mathrm{H}, \mathrm{NH}), 7.12\left(\mathrm{~d}, 1 \mathrm{H}, \mathrm{H} 5,{ }^{3} J_{\mathrm{HH}}=8.1 \mathrm{~Hz}\right), 7.45\left(\mathrm{~d}, 1 \mathrm{H}, \mathrm{H} 8,{ }^{4} J_{\mathrm{HH}}=2.7 \mathrm{~Hz}\right), 8.50(\mathrm{~s}, 1 \mathrm{H}, \mathrm{OH}) .{ }^{13} \mathrm{C}$ NMR (75.45 MHz, acetone- $\left.d_{6}\right): \delta 30.8\left(\mathrm{~s}, \mathrm{CH}_{2}\right), 52.6$ (s, OMe), 53.9 (s, CH), 114.5 (s, CH, C8), 120.1 (s, CH, C6), 128.0 (s, C4a), 129.6 (s, CH, C5), 130.9 (s, C8a), 157.4 (s, C7), 165.3 (s, CO), 172.7 (s, $\left.\mathrm{CO}_{2} \mathrm{Me}\right)$. ESI-HRMS: exact mass calcd for $\mathrm{C}_{11} \mathrm{H}_{11} \mathrm{NO}_{4} 221.0685$; found 221.0688. $[\alpha]_{\mathrm{D}}^{20}=+26.86(\mathrm{c}=$ $0.20, \mathrm{MeOH})$.

Synthesis of 6,7-Dimethoxy-3,4-dihydroisoquinolin-1(2H)-one (10b). CO was bubbled through a suspension of complex $\mathbf{1 b}-\mathbf{B r} \cdot \mathrm{H}_{2} \mathrm{O}(145 \mathrm{mg}, 0.19 \mathrm{mmol})$ in $\mathrm{CH}_{2} \mathrm{Cl}_{2}(20 \mathrm{~mL})$, and the resulting mixture was stirred under a CO atmosphere for $16 \mathrm{~h}$. Decomposition to metallic palladium was observed. The mixture was filtered through a plug of $\mathrm{MgSO}_{4}$, the filtrate was concentrated to ca. $2 \mathrm{~mL}$, and $\mathrm{Et}_{2} \mathrm{O}$ (30 $\mathrm{mL})$ was added. The suspension was filtered, and the solid was washed with $\mathrm{Et}_{2} \mathrm{O}(2 \times 5 \mathrm{~mL})$ to give compound 10b pale yellow solid. Yield: $47 \mathrm{mg}, 0.23 \mathrm{mmol}, 59 \%$. IR $\left(\mathrm{cm}^{-1}\right): v(\mathrm{NH}) 3176 \mathrm{~m} ; v(\mathrm{CO})$ 1655 s. ${ }^{1} \mathrm{H}$ NMR (200.13 MHz): $\delta 2.94$ (“t”, $2 \mathrm{H}, \mathrm{CH}_{2} \mathrm{Ar},{ }^{3} J_{\mathrm{HH}}=6.6 \mathrm{~Hz}$ ), 3.56 (“td", $2 \mathrm{H}, \mathrm{CH}_{2} \mathrm{~N},{ }^{3} J_{\mathrm{HH}}=$ 6.6, $\left.{ }^{3} J_{\mathrm{HH}}=2.4 \mathrm{~Hz}\right), 3.93(\mathrm{~s}, 6 \mathrm{H}, \mathrm{Me}, \mathrm{OMe}), 5.97(\mathrm{br} \mathrm{s}, 1 \mathrm{H}, \mathrm{NH}), 6.68$ (s, $\left.1 \mathrm{H}, \mathrm{H} 5\right), 7.57$ (s, $\left.1 \mathrm{H}, \mathrm{H} 8\right)$. ${ }^{13} \mathrm{C}\left\{{ }^{1} \mathrm{H}\right\}$ NMR (75.45 MHz): $\delta 28.0\left(\mathrm{~s}, \mathrm{CH}_{2} \mathrm{Ar}\right), 40.5\left(\mathrm{~s}, \mathrm{CH}_{2} \mathrm{~N}\right), 56.0$ (s, OMe), 56.1 (s, OMe), 109.5 (s, CH, C5), 110.1 (s, CH, C8), 121.3 (s, C8a), 132.6 (s, C4a), 148.0 (s, C7), 152.1 (s, C6), 166.3 (s, CO). Spectroscopic data are in agreement to those in the literature $\left({ }^{1} \mathrm{H}\right.$ and $\left.{ }^{13} \mathrm{C} N \mathrm{NR}\right) .{ }^{53}$

Single-Crystal X-ray Structure Determinations. Relevant crystallographic data and details of the refinement for the structures of compounds Ia-2MeCN, 3a-OAc, $\mathbf{6 b}-\mathbf{B r}, \mathbf{6 b}-\mathbf{O A c} \cdot \mathrm{H}_{2} \mathrm{O}$ and $\mathbf{7 b}-\mathbf{O A c}$ are summarized in the Supplementary Material. Data Collection: Crystals suitable for X-ray diffraction were mounted in inert oil on a glass fiber and transferred to a Bruker SMART APEX diffractometer. 
Data were recorded at $100(2) \mathrm{K}$ using graphite-monochromated Mo K $\alpha$ radiation $(\lambda=0.71073 \AA)$ and $\omega$-scan mode. Multiscan absorption corrections were applied. Solution and Refinements: Crystal structures were solved by Patterson $\left(\mathbf{6 b}-\mathbf{O A c} \cdot \mathrm{H}_{2} \mathrm{O}\right)$ or direct method $(\mathbf{I a} \cdot 2 \mathrm{MeCN}, \mathbf{3 a}-\mathbf{O A c}, \mathbf{6 b}-\mathbf{B r}$ and 7b-OAc) and all nonhydrogen atoms refined anisotropically on $F^{2}$ using the program SHELXL-97. ${ }^{58}$ Hydrogen atoms were refined as follows: Complexes Ia·2MeCN: $\mathrm{NH}_{2}$ and $\mathrm{OH}$, free with DFIX; ordered methyl, rigid group; all others, riding. Complex 3a-OAc: $\mathrm{NH}_{2}$ and $\mathrm{OH}$, free with DFIX; methyl, rigid group; all others, riding. Complex 6b-Br: $\mathrm{NH}_{2}$, free with SADI; methyl, rigid group; all others, riding. Complex 6b-OAc $\cdot \mathrm{H}_{2} \mathrm{O}: \mathrm{H}_{2} \mathrm{O}$, free with $\mathrm{SADI} ; \mathrm{NH}_{2}$, free; methyl, rigid group; all others, riding. Complex 7b-OAc: $\mathrm{NH}_{2}$, free with $\mathrm{SADI}$; ordered methyl, rigid group; all others, riding. Special features: Complex Ia-2MeCN: C10 is disordered over two positions, with a ca. 53:47\% occupancy distribution. Complex 3a-OAc: A region of residual electron density could not be interpreted in terms of realistic solvent molecules, even allowing for possible disorder. For this reason the program SQUEEZE, which is part of the PLATON system, ${ }^{59}$ was employed to remove mathematically the effects of the solvent. Standard deviations of refined parameters should be interpreted with caution. The void volume per cell was $250 \AA^{3}$, with a void electron count per cell of 83 . This solvent was not taken into account when calculating derived parameters such as the formula weight, because the nature of the solvent was uncertain. The $\mathrm{CO}_{2} \mathrm{Me}$ group is disordered over two positions with a ca. 52:48\% occupancy distribution. Complex 7b-OAc: A region of residual electron density could not be interpreted in terms of realistic solvent molecules, even allowing for possible disorder. For this reason the program SQUEEZE, which is part of the PLATON system, was employed to remove mathematically the effects of the solvent. Standard deviations of refined parameters should be interpreted with caution. The void volume per cell was $184 \AA^{3}$, with a void electron count per cell of 46 . This solvent was not taken into account when calculating derived parameters such as the formula weight, because the nature of the solvent was uncertain. One OMe goup is disordered over two positions with a ca. 55:45\% occupancy distribution.

\section{CONCLUSION}


Ortho-palladated complexes derived from homoveratrylamine and L-tyrosine methyl ester, both biologically relevant arylalkylamines, can be easily prepared by reacting their corresponding triflates and $\mathrm{Pd}(\mathrm{OAc})_{2}$, in a 1:1 molar ratio, in acetonitrile at $78^{\circ} \mathrm{C}$. In this conditions, ortho-palladation of the homoveratrylamine occurs regiospecifically at C6 position. The use of the triflate salts instead of the free arylalkylamines as starting materials in the ortho-palladation reactions offers evident advantages: (1) it avoids the formation of undesirable by-products, which in the case of L-tyrosine methyl ester derive from its acidic $\mathrm{OH}$ group and (2) the ortho-palladated complexes are obtained in better yields. These cyclopalladated complexes can be used as intermediates in organic synthesis, as proved by the fact that their reactions with $\mathrm{CO}$ render the corresponding tetrahydroisoquinolones. We have investigated the published ortho-palladation of homoveratrylamine and found that, in our hands, instead of palladation at $\mathrm{C} 2$ a mixture containing coordination and cyclopalladated complexes at C6 were obtained.

\section{ACKNOWLEDGMENT}

We thank the Ministerio de Educación y Ciencia (Spain), FEDER (Project CTQ2007-60808/BQU) and Fundación Séneca (04539/GERM/06) for financial support. J.-A. G.-L. and M.-J. O.-M. are grateful to the Fundación Séneca (CARM, Spain) and Ministerio de Educación y Ciencia (Spain), respectively, for their research grants. We thank the Departamento de Química Orgánica of the University of Murcia for the facilities offered to use the polarimeter and Dr. José Berná for his valuable help.

\section{Supporting Information Available: Experimental details for the synthesis of 2-bromo-3,4-} dimethoxyphenethylamine, details (including symmetry operators) of hydrogen bondings and listing of all refined and calculated atomic coordinates, anisotropic thermal parameters, bond lengths and angles, CIF files for complexes, table of crystallographic data of Ia-2MeCN, 3a-OAc, $\mathbf{6 b}-\mathbf{B r}, \mathbf{6 b}-\mathbf{O A c} \cdot \mathrm{H}_{2} \mathrm{O}$ and 7b-OAc. This material is available free of charge via the Internet at http://pubs.acs.org. 


\section{REFERENCES}

(1) Herrmann, W. A.; Böhm, V. P. W.; Reisinger, C.-P. J. Organomet. Chem. 1999, 576, 23. van der Boom, M. E.; Milstein, D. Chem. Rev. 2003, 103, 1759. Beletskaya, I. P.; Cheprakov, A. V. J. Organomet. Chem. 2004, 689, 4055. Alonso, D. A.; Najera, C. Chem. Soc. Rev. 2010, 39, 2891.

(2) Dupont, J.; Consorti, C. S.; Spencer, J. Chem. Rev. 2005, 105, 2527.

(3) Ryabov, A. D. Synthesis 1985, 233. Omae, I. Coord. Chem. Rev. 2004, 248, 995.

(4) Pfeffer, M.; Dupont, J. Palladacycles, Synthesis, Characterization and Applications; WileyVCH: Weinheim, Germany, 2008. Aguilar, D.; Cuesta, L.; Nieto, S.; Serrano, E.; Urriolabeitia, E. P. Curr. Org. Chem. 2011, 15, 3441.

(5) Vicente, J.; Abad, J. A.; Gil-Rubio, J.; Jones, P. G. Organometallics 1995, 14, 2677. Vicente, J.; Abad, J. A.; Lopez-Serrano, J.; Jones, P. G.; Najera, C.; Botella-Segura, L. Organometallics 2005, 24, 5044. Vicente, J.; Abad, J. A.; Gil-Rubio, J.; Jones, P. G. Inorg. Chim. Acta 1994, 222, 1.

(6) Vicente, J.; Saura-Llamas, I.; Grünwald, C.; Alcaraz, C.; Jones, P. G.; Bautista, D. Organometallics 2002, 21, 3587.

(7) Vicente, J.; Saura-Llamas, I.; Bautista, D. Organometallics 2005, 24, 6001.

(8) Vicente, J.; Saura-Llamas, I.; García-López, J. A.; Calmuschi-Cula, B.; Bautista, D. Organometallics 2007, 26, 2768.

(9) Vicente, J.; Saura-Llamas, I.; García-López, J. A.; Bautista, D. Organometallics 2009, 28, 448.

(10) Vicente, J.; Saura-Llamas, I.; García-López, J. A.; Bautista, D. Organometallics 2010, 29, 4320.

(11) Nieto, S.; Sayago, F. J.; Laborda, P.; Soler, T.; Cativiela, C.; Urriolabeitia, E. P. Tetrahedron 2011, 67, 4185. Nieto, S.; Arnau, P.; Serrano, E.; Navarro, R.; Soler, T.; Cativiela, C.; Urriolabeitia, E. P. Inorg. Chem. 2009, 48, 11963. 
(12) Doménech, A.; Navarro, P.; Arán, V. J.; Muro, B.; Montoya, N.; García-España, E. Analyst 2010, $135,1449$.

(13) Cope, A. C.; Friedrich, E. C. J. Am. Chem. Soc. 1968, 90, 909. Dunina, V. V.; Zalevskaya, O. A.; Potapov, V. M. Russ. Chem.Rev. 1988, 57, 250. Ryabov, A. D. Chem. Rev. 1990, 90, 403.

(14) Kurzeev, S. A.; Kazankoz, G. M.; Ryabov, A. D. Inorg. Chim. Acta 2002, 340, 192.

(15) Vicente, J.; Saura-Llamas, I. Comments Inorg. Chem. 2007, 28, 39.

(16) Fuchita, Y.; Tsuchiya, H.; Miyafuji, A. Inorg. Chim. Acta 1995, 233, 91. Fuchita, Y.; Yoshinaga, K.; Ikeda, Y.; Kinoshita-Kawashima, J. J. Chem. Soc., Dalton Trans. 1997, 2495. Hajipour, A. R.; Karami, K.; Pirisedigh, A.; Ruoho, A. E. Amino Acids 2009, 37, 537.

(17) Vicente, J.; Saura-Llamas, I.; Palin, M. G.; Jones, P. G.; Ramírez de Arellano, M. C. Organometallics 1997, 16, 826.

(18) Vicente, J.; Saura-Llamas, I.; Cuadrado, J.; Ramírez de Arellano, M. C. Organometallics 2003, $22,5513$.

(19) Vicente, J.; Saura-Llamas, I.; Oliva-Madrid, M. J.; García-López, J. A.; Bautista, D. Organometallics 2011, 30, 4624.

(20) Hajipour, A. R.; Karami, K.; Pirisedigh, A.; Ruoho, A. R. J. Organomet. Chem. 2009, 694, 2548.

(21) Yamamoto, Y.; Yamazaki, H. Inorg. Chim. Acta 1980, 41, 229.

(22) Dupont, J.; Pffefer, M.; Daran, J. C.; Jeannin, Y. Organometallics 1987, 6, 899. Dupont, J.; Pfeffer, M. J. Chem. Soc., Dalton Trans. 1990, 3193.

(23) Zografidis, A.; Polborn, K.; Beck, W.; Markies, B. A.; van Koten, G. Z. Naturforsch., B 1994, $49,1494$. 
(24) Delis, J. G. P.; Aubel, P. G.; Vrieze, K.; van Leeuwen, P. W. N. M.; Veldman, N.; Spek, A.; van Neer, F. J. R. Organometallics 1997, 16, 2948.

(25) Ryabov, A. D.; van Eldik, R.; Le Borgne, G.; Pfeffer, M. Organometallics 1993, 12, 1386.

(26) Holton, R. A.; Davis, R. G. J. Am. Chem. Soc. 1977, 99, 4175.

(27) Dunina, V. V.; Kuz'mina, L. G.; Kazakova, M. Y.; Gorunova, O. N.; Grishin, Y. K.; Kazakova, E. I. Eur. J. Inorg. Chem. 1999, 1029.

(28) Vicente, J.; Arcas, A.; Fernández-Hernández, J. M.; Bautista, D. Organometallics 2001, 20, 2767.

(29) Vicente, J.; Arcas, A.; Bautista, D.; Jones, P. G. Organometallics 1997, 16, 2127. Vicente, J.; Abad, J. A.; Martínez-Viviente, E.; Jones, P. G. Organometallics 2002, 21, 4454. Crespo, M.; Granell, J.; Solans, X.; Font-Bardia, M. J. Organomet. Chem. 2003, 681, 143. Vicente, J.; Arcas, A.; GálvezLópez, M.-D.; Juliá-Hernández, F.; Bautista, D.; Jones, P. G. Organometallics 2008, 27, 1582.

(30) Vicente, J.; Abad, J.-A.; Frankland, A. D.; Ramírez de Arellano, M. C. Chem. Eur. J. 1999, 5, 3066. Larraz, C.; Navarro, R.; Urriolabeitia, E. P. New J. Chem. 2000, 24, 623. Vicente, J.; Arcas, A.; Bautista, D.; Ramírez de Arellano, M. C. J. Organomet. Chem. 2002, 663, 164. Rodríguez, N.; Cuenca, A.; Ramírez de Arellano, C.; Medio-Simón, M.; Peine, D.; Asensio, G. J. Org. Chem. 2004, 69, 8070.

(31) Böhm, A.; Polborn, K.; Sünkel, K.; Beck, W. Z. Naturforsh., B: J. Chem. Sci. 1998, 53, 448.

(32) Ma, J.-F.; Kojima, Y.; Yamamoto, Y. J. Organomet. Chem. 2000, 616, 149.

(33) Vicente, J.; Abad, J. A.; Frankland, A. D.; López-Serrano, J.; Ramírez de Arellano, M. C.; Jones, P. G. Organometallics 2002, 21, 272. Vicente, J.; Arcas, A.; Gálvez-López, M. D.; Jones, P. G. Organometallics 2006, 25, 4247. Vicente, J.; Arcas, A.; Gálvez-López, M. D.; Jones, P. G.; Bautista, D. Organometallics 2009, 28, 3501 . 
(34) Mosteiro, R.; Perille, E.; Fernández, A.; López-Torres, M.; Vila, J. M.; Suárez, A.; Ortigueira, J. M.; Pereira, M. T.; Fernández, J. J. Appl. Organometal. Chem. 2000, 14, 634.

(35) Pfeffer, M.; Sutter, J.-P.; Urriolabeitia, E. P. Inorg. Chim. Acta 1996, 249, 63.

(36) Barr, N.; Dyke, S. F. J. Organomet. Chem. 1983, 243, 223.

(37) Selvakumar, K.; Vancheesan, S. Polyhedron 1996, 15, 2535.

(38) Selvakumar, K.; Vancheesan, S. Polyhedron 1997, 16, 2405.

(39) Albert, J.; Granell, J.; Moragas, R.; Font-Bardia, M.; Solans, X. J. Organomet. Chem. 1996, 522, 59.

(40) Vila, J. M.; Suarez, A.; Pereira, M. T.; Gayoso, E.; Gayoso, M. Polyhedron 1987, 6, 1003.

(41) Cativiela, C.; Falvello, L. R.; Ginés, J. C.; Navarro, R.; Urriolabeitia, E. P. New J. Chem. 2001, 25,344 .

(42) Tollari, S.; Cenini, S.; Tunice, C.; Palmisano, G. Inorg. Chim. Acta 1998, 272, 18.

(43) Roiban, D.; Serrano, E.; Soler, T.; Grosu, I.; Cativiela, C.; Urriolabeitia, E. P. Chem. Commun. 2009, 4681 .

(44) Cattalini, L.; Martelli, M. J. Am. Chem. Soc. 1969, 91, 312. Calmuschi, B.; Jonas, A. E.; Englert, E. Acta Crystallogr., Sect. C: Cryst. Struct. Commun. 2004, 60, m320.

(45) Jones, W. D.; Reynolds, K. A.; K. Sperry, C. K.; Lachicotte, R. J. Organometallics 2000, 19, 1661. Lin, S. T.; Peng, K. J.; Barclay, T. M.; Cordes, A. W. Inorg. Chim. Acta 2001, 321, 89. Sui-Seng, C.; Enright, G. D.; Zargarian, D. J. Am. Chem. Soc. 2006, 128, 6508.

(46) Biscoe, M. R.; Fors, B. P.; Buchwald, S. L. J. Am. Chem. Soc. 2008, 130, 6686. 
(47) Thompson, J. M.; Heck, R. F. J. Org. Chem. 1975, 40, 2667. Barr, N.; Bartley, J. P.; Clark, P. W.; Dunstan, P.; Dyke, S. F. J. Organomet. Chem. 1986, 302, 117. Omae, I. J. Organomet. Chem. 2007, 692, 2608. Omae, I. Coord. Chem. Rev. 2011, 255, 139.

(48) Orito, K.; Horibata, A.; Nakamura, T.; Ushito, H.; Nagasaki, H.; Yuguchi, M.; Yamashita, S.; Tokuda, M. J. Am. Chem. Soc. 2004, 126, 14342. Haffemayer, B.; Gulias, M.; Gaunt, M. J. Chem. Sci. 2011, 2, 312. Li, H.; Cai, G.-X.; Shi, Z.-J. Dalton Trans. 2010, 39, 10442.

(49) Orito, K.; Miyazawa, M.; Nakamura, T.; Horibata, A.; Ushito, H.; Nagasaki, H.; Yuguchi, M.; Yamashita, S.; Yamazaki, H.; Tokuda, M. J. Org. Chem. 2006, 71, 5951.

(50) López, B.; Rodriguez, A.; Santos, D.; Albert, J.; Ariza, X.; Garcia, J.; Granell, J. Chem. Commun. 2011, 47, 1054.

(51) O’Sullivan, R. D.; Parkins, A. W. J. Chem. Soc., Chem. Commun. 1984, 1165.

(52) Ide, S.; Sener, B.; Temizer, H.; Könuköl, S. Cryst. Res. Technol. 1996, 31, 617. Kucukboyaci, N.; Bingol, F.; Sener, B.; Kutney, J. P.; Stoynov, N. Nat. Prod.Sci. 1998, 4, 257.

(53) Bois-Choussy, M.; De Paolis, M.; Zhu, J. Tetrahedron Lett. 2001, 42, 3427.

(54) Judd, K. E.; Mahon, M. F.; Caggiano, L. Synthesis 2009, 2809. Sharma, S. D.; Mehra, U.; Gupta, P. K. Tetrahedron 1980, 36, 3427. Chern, M.-S.; Li, W.-R. Tetrahedron Lett. 2004, 45, 8323. Meyer, M. D.; Altenbach, R. J.; Bai, H.; Basha, F. Z.; Carroll, W. A.; Kerwin Jr., J. F.; Lebold, S. A.; Lee, E.; Pratt, J. K.; Sippy, K. B.; Tietje, K.; Wendt, M. D.; Brune, M. E.; Buckner, S. A.; Hancock, A. A.; Drizin, I. J. Med. Chem. 2001, 44, 1971.

(55) Vicente, J.; Chicote, M.-T. Inorg. Synth. 1998, 32, 172.

(56) Takahashi, Y.; Ito, T.; Sakai, S.; Ishii, Y. J. Chem. Soc. D. 1970, 1065. 
(57) Weinstock, J.; Ladd, D. L.; Wilson, J. W.; Brush, C. K.; Yim, N. C. F.; Gallagher, G. J.; McCarthy, M. E.; Silvestri, J.; Sarau, H. M.; Flaim, K. E.; Ackerman, D. M.; Setler, P. E.; Tobia, A. J.; Hahn, R. A. J.Med.Chem. 1968, 29, 2315.

(58) Sheldrick, G. M. SHELX-97; University of Göttingen, Göttingen, Germany, 1997.

(59) Spek, A. L. PLATON. A Multipurpose Crystallographic Tool (Version 260109). University of Utrecht: The Netherlands, 1980-2009. Spek, A. L. Acta Crystallogr., Sect. D: Biol. Crystallogr. 2009, 65, 148 . 
For the Table of Contents

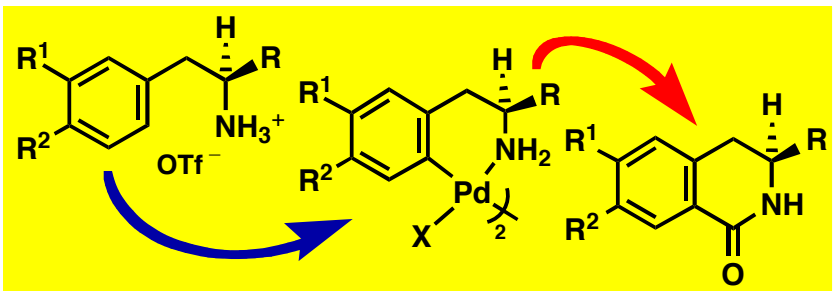

